Nevada

Environmental

Restoration

Project

\title{
Corrective Action
}

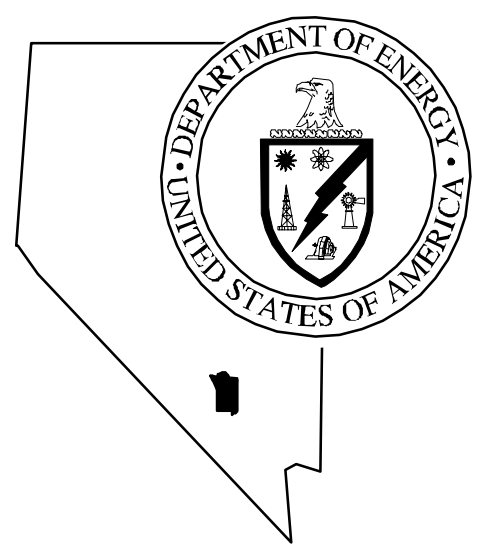

\section{Investigation Plan for}

Corrective Action Unit 486:

Double Tracks RADSAFE Area

Nellis Air Force Range, Nevada

Controlled Copy No.:

Revision No.: 0

October 1998

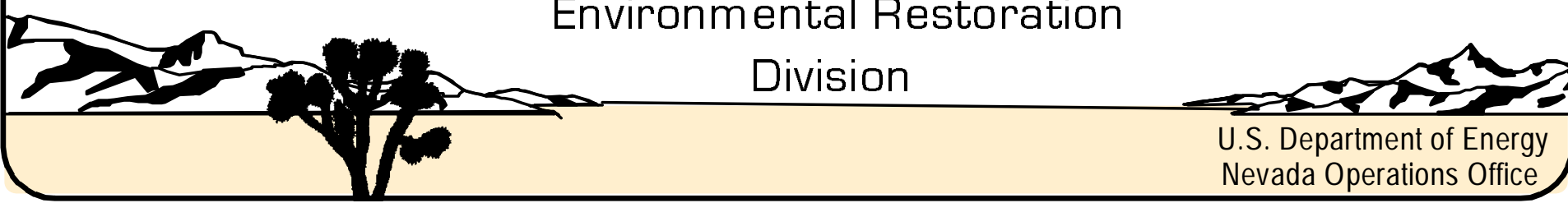


Available to the public from -

U.S. Department of Commerce

National Technical Information Service

5285 Port Royal Road

Springfield, VA 22161

(703) 487-4650

Available electronically at http://www.doe.gov/bridge. Available to

U.S. Department of Energy and its contractors in paper from -

U.S. Department of Energy

Office of Scientific and Technical Information

P.O. Box 62

Oak Ridge, TN 37831-0062

(423) 576-8401 


\section{CORRECTIVE ACTION INVESTIGATION PLAN FOR CORRECTIVE ACTION UNIT 486: DOUBLE TRACKS RADSAFE AREA NELLIS AIR FORCE RANGE, NEVADA}

DOE Nevada Operations Office

Las Vegas, Nevada

Controlled Copy No.:

Revision No.: 0

October 1998

Approved for public release; further dissemination unlimited 


\title{
CORRECTIVE ACTION INVESTIGATION PLAN FOR CORRECTIVE ACTION UNIT 486: DOUBLE TRACKS RADSAFE AREA NELLIS AIR FORCE RANGE, NEVADA
}

\begin{abstract}
Approved by:

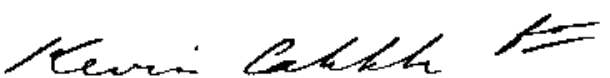

Janet Appenzeller-Wing, Project Manager Industrial Sites Subproject
\end{abstract}

Date: $10-8-98$

fo Approved by:

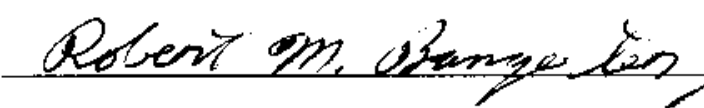
Date: $10 / 8 / 98$

Runore C. Wycoff, Project Manager

Nevada Environmental Restoration Project 


\section{RECORD OF TECHNICAL CHANGE}

Technical Change No. 1 Page $\ldots .1-$ of -2 Date $11-16-98$

Project Job Name CAU 486 CAIP

The following technical changes (inciuding justification) are requested by:

Cheryl Rodriguez

(Name)
Industrial Sites Task Manager

(Title)

Chartges to the Corrective Action Investigation Plan for CAU 486: Double Tracks RADSAFE Area, Nellis Air Force Range, Nevada, Rev. 0; DOE/NV--523

Inside cover page: Insert the following Trademark Disclosure statement, "Reference herein to any specific commercial product, process, or service by trade name, trademark, manufacturer, or otherwise, does not necessarily constitute or imply its endorsement, recommendation, or favoring by the United States Government or any agency thereof or its contractors or subcontractors."

Page 19, Section 3.3.1, Par. 2: Add "and Attachment 3," to the sentence. Attachment 3 details newly added procedures to the methodology for determining field screening levels for the site investigation. The revised sentence will read: "Details of the methodology to determine the radiological field screening levels can be found in Table A.3-1, Attachment 2, and Attachment 3 of the DQO worksheet (Appendix A)."

Page 21, Table 3-1, Column 3, Rows 6, 7, and 8: Correction - The footnotes attached to the analytical methods listed in rows 6,7 , and 8 are incorrect. The methods listed in rows 6 and 7 will read: "NAS-NS-3058.." The method listed in row 8 will read: "NAS-NS-3058 $8^{\mathrm{e}, \mathrm{f}}$."

Page 21, Table 3-1, Column 3, Rows 6, 7, and 8: Insert the text "or equivalent method" after the analytical methods. The text in rows 6 and 7 will read: "NAS-NS-3058 eq.8 or equivalent method." The text in row 8 will read: "NAS-NS-3058, or equivalent method."

Page 25, Section 4.2, Par. 5: Delete "then two consecutive clean soil samples will be collected from random excavated test pits" from the first sentence. The revised sentence will read: "In the event the decon facility trench boundaries cannot be delineated by visual assessment and field screening results are below field screening levels, then one confirmatory sample per random sample location will be collected for off-site laboratory analysis to confirm COPCs are below preliminary action levels."

Justification: In developing the number and locations of random confirmatory samples, using guidance from MARSSIM and NUREG 1505, only one soil sample is required from each random sample location. 
Page 36, Section 5.3.3: Delete Paragraph 3 and insert: "Alpha spectroscopy in the form of isotopic plutonium and uranium is included in the required site characterization analyses to determine if the waste will meet the Nevada Test Site Performance Objectives for Certification of Nonradioactive Hazardous Waste (BN, 1995). This analysis is included in the event the waste generated during site characterization is determined to be hazardous waste. Gamma spectroscopy is not included in the site characterization analyses because process knowledge information did not indicate the potential for gamma radionuclide contamination."

Page 40: Add new reference: "Adams, Steven. 1998d. Memo to D. Arnold regarding 'Daily Response Check of FIDLER at the Double Tracks RADSAFE Area,' 16 November. Las Vegas, NV: IT Corporation."

Appendix A, Page A-4, Table A.3-1: Insert the following sentence at the end of the existing text in Row 5, Column 4: "To account for daily variations of instrument response, an additional procedure in determining field screening levels will be implemented. This new procedure is detailed in Attachment 3."

Appendix A, Page A-4, Table A.3-1: Add the reference "Adams, 1998d" to row 5 of Column 7.

Appendix A, Page A-4, Table A.3-1: Insert the text "or equilavent method" after the analytical methods in rows 6 and 7 of Column 5 . The text in row 6 will read: "NAS-NS-3058 or equivalent method." The text in row 7 will read: "NAS-NS-3050 or equivalent method."

Appendix A: Add the memo titled "Daily Response Check of FIDLER at the Double Tracks RADSAFE Area," as Attachment 3. The memo is referenced as Adams, 1998d.

The project time will be (Increased)(Decreased)(Unchanged) by approximately $-0-$ days

Applicable Project-Specific Document(s): Corrective Action Investigation Plan for Corrective Action Unit 486 : Double Tracks RADSAFE Area, Nellis Air Force Range, Nevada, Rev, 0; DOE/NV--523

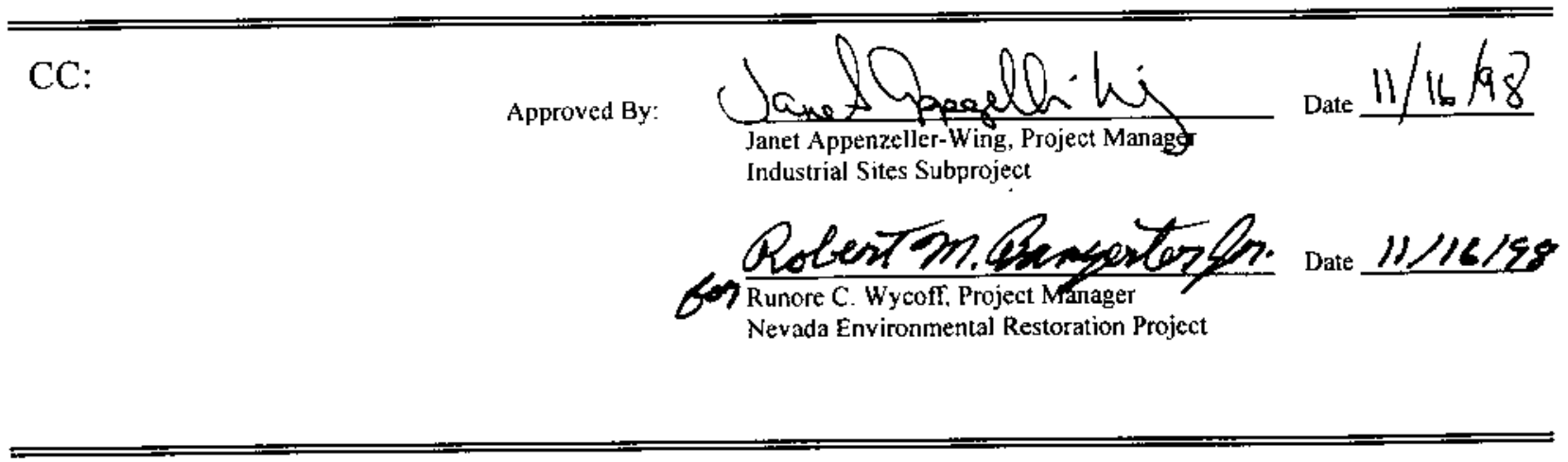




\section{Attachment 3}

"Daily Response Check of FIDLER at the Double Tracks RADSAFE Area” (Adams, 1998d) 


\section{DAILY RESPONSE CHECK OF FIDLER AT THE DOUBLE TRACKS RADSAFE AREA}

\section{Summary}

Health Physics recommends that daily field screening levels be determined for gross gamma monitoring at the Double Tracks RADSAFE Area. This recommendation is predicated on the fact that there is significant daily variation in gross gamma detector response, even in the absence of a radiation source. Calculating daily field screening levels will help ensure the detection of radiation contamination in soil.

The following sections of this memorandum discuss the radiation survey instruments that will be used during the characterization of the Double Tracks site, the anticipated radionuclides in the radiological source term, the survey instrument response to these radionuclides, the definition of the field screening levels, and recommendations on how to select the daily gross gamma field screening level.

\section{Survey Instruments}

Soil samples will be monitored for gross alpha activity, gross beta activity, and gross gamma activity at the Double Tracks RADSAFE Area (DTRSA) using hand-held portable radiation survey instruments. An Electra alpha/beta scintillator counter is used for monitoring the gross alpha and gross beta activity of soil samples. A Field Instrument for the Detection of Low-Energy Radiation (FIDLER) will be used to monitor the low energy gamma activity of soil samples. These survey instruments are used to monitor both the radiation activity in soil samples taken from the DTRSA during characterization activities and the soil samples taken from undisturbed background locations in the vicinity of the DTRSA.

\section{DTRSA Radioactive Source Term}

The DTRSA radioactive source term is the plutonium and depleted uranium from the Double Tracks safety shot experiment. Vehicles, equipment, and workers that were contaminated during the experiment were decontaminated at the DTRSA. The radiological source term consists of four plutonium isotopes, plutonium-238, 239,240, and 241; and uranium-238 (AEC, 1964). Plutonium-238, 239, 240 and uranium-238 emit alpha particles and very low energy photons during radioactive decay. Plutonium-241 is a beta emitter that decays to americium-241. Americium-241 is an alpha emitter that also emits a 59.5 kiloelectron volt 
Approximately 95 percent of the emissions from the radioactive source term at Double Tracks are alpha particles and low energy beta particles (AEC, 1964 and Kocher, 1981). These alpha and beta emitting radionuclides cannot be detected unless they are on or very near the soil surface. Alpha particles are not capable of penetrating more than a millimeter ( 0.04 inches) of soil. Therefore, alpha emitting radionuclides that are more than a millimeter below the soil surface will not be detected using an alpha detector. Beta particles are not capable of penetrating more than a centimeter ( 0.4 inches) of soil. Beta emitting radionuclides that are more than a centimeter below the soil surface cannot be detected using a beta detector. The distance an alpha or beta particle can penetrate in soil is affected by the soil moisture. An increase in the soil moisture will decrease the distance they can penetrate. Gamma particles and photons, depending on their energy, are capable of penetrating several centimeters to a meter (39.4 inches) of soil. The $59.5 \mathrm{keV}^{241} \mathrm{Am}$ gamma is capable of penetrating about 5 centimeters ( 2 inches) of soil.

During the last twenty years the concentration of ${ }^{241} \mathrm{Am}$ and two other plutonium contaminants, plutonium-239/240 $\left({ }^{239 / 240} \mathrm{Pu}\right)$ has been measured in hundreds of Double Tracks Site soil samples using alpha spectrometry. The ratio of the ${ }^{239: 240} \mathrm{Pu}$ concentration in the soil samples to the ${ }^{241} \mathrm{Am}$ concentration in the soil samples varied from six to one to 14 to one (DOE, 1996). Information on the initial Double Tracks Site source term, combined with the information obtained from alpha spectrometry, suggests that the ratio of total plutonium ( $\mathrm{Pu}-238,239,240$, and 241) concentration in the soil to the ${ }^{241} \mathrm{Am}$ concentration varies from ten to one to 20 to one. Survey instruments that can detect the $59.5 \mathrm{keV}$ photon emitted by the ${ }^{241} \mathrm{Am}$ in a soil sample would therefore, be providing indirect information on the concentration of the plutonium isotopes in the soil sample.

\section{Survey Instrument Response}

The count rate displayed by a survey instrument is a function of two components. One component is due to the instrument detector response to radiation emitted by the radionuclides present in the environment and to cosmic rays. The second component of the count rate is due to the electronic noise in the instrument. Even in the absence of any radioactivity all survey instruments will have a count rate due to this second component. The count rate due to this second component varies significantly for different types of instruments and between different instruments of the same type. The background count rate of a survey instrument is then a combination of the counts due to the natural background concentration of radionuclides in the environment, cosmic rays, and the electronic noise.

The background count rate of a survey instrument is effected by environmental parameters such as temperature, humidity and air pressure. The changes in the environment effect both the radiation background and the electronic noise in the survey instrument. Soil humidity and temperature, air humidity and temperature, and air pressure effect the release rate of radon gas from the soil. Changes in the concentration of radon gas and its radioactive decay products in the soil and air will result in changes in the survey instrument count rate. Changes in temperature,

LV/11-16-98/G:UINDUST 1IND_SITEIDTRSA_DC.WPD

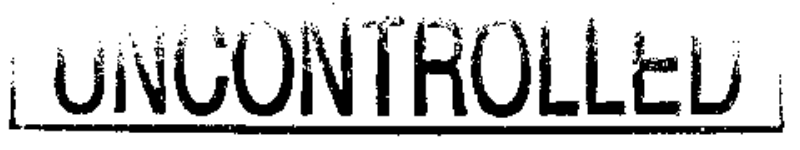


humidity, and air pressure will also result in changes in the count rate due to their effect on the instrument's electronic noise. The impacts of environmental parameters on the background count rate of a survey instrument is a function of the type of detector, type of electronic circuits, and the survey instrument design.

The Electra alpha/beta scintillation counter measures the alpha and beta activity on or near the soil surface. The background count rate of the Electra is very stable and it is not strongly affected by environmental conditions. The FIDLER background count rate is highly variable. The variability is due to the sensitivity of the FIDLER's photomultiplier tube to temperature and the FIDLER's response to the low energy photons emitted by radon gas and its decay products.

The FIDLER operates by converting kinetic energy of low energy photons and gammas into light. A photomultiplier tube then converts the extremely weak light output of the scintillation pulse into a corresponding electrical signal which is then converted to a count rate. The superior photosensitivity in modern photomultiplier tubes is achieved only at the price of a higher noise rate from thermal stimulated electron emissions (Knoll, 1979). The electron noise in the photomultiplier tube is a direct function of temperature. The design of the photomultiplier tube causes the FIDLER count rate to be sensitive to temperature.

The detector in the FIDLER is sensitive to some low energy photons emitted by radon decay products. The emission rates of radon gas from the soil are sensitive to changes in the soil humidity and temperature, air pressure, and air temperature. As a consequence, the FIDLER's count rate at a survey location will then be affected by those environmental conditions that affect the emission rate of radon gas from the soil.

\section{Field Screening Levels}

A field screening level (FSL) is used in comparing the radiation activity in site characterization soil samples to soil samples taken from undisturbed background locations. The FSL is defined by monitoring the surface soil at 20 points at an undisturbed background location or 20 soil samples taken from undisturbed background soil locations. The mean count rate and the standard deviation of the mean count rate for the 20 samples are then calculated and documented. The FSL is then defined as the mean count rate plus two standard deviations of the mean. A separate FSL is defined for the gross alpha activity, gross beta activity, and gross gamma activity. If a site soil sample exceeds the FSL for any of these three measurements, than soil samples from additional locations may be required to be monitored in order to determine the lateral and vertical extent of the radioactive contamination. In addition, more soil samples may have to be sent to a laboratory for radioanalysis. It is important that the FSL are accurately defined to ensure efficient and productive use of resources during DTRSA characterization.

\section{Implementation of the FSL}

The Electra alpha/beta scintillator background count rate has been found to be stable. Its daily variation in the absence of a radioactive source does not preclude its use for establishing FSL 
based upon the initial 20 background soil samples. The FIDLER background count rate is not as stable as the Electra. Data collected during Roller Coaster RADSAFE Area (RCRSA) and Soils Subproject characterization demonstrates that the variation in the FIDLER count rate exceeds the FIDLER response to the variation in the concentration of radionuclides in the natural background. Therefore, a daily adjustment must be established for the FIDLER FSL. Information supporting these conclusions will be found in the following paragraphs.

The FSL process was used during characterization of the RCRSA. There was no difficulty in applying the FSL process when screening gross alpha and gross beta activity using the Electra. However, the screening of gross gamma activity using the FIDLER demonstrated that the process was inadequate and requires modification. The original FSL process did not account for the daily variation in the count rate of the FIDLER. When no radiation source is present, the daily count rate of the FIDLER exceeds the count rate response due to the variation in the concentration of radionuclides found in soil at background locations. This was not true for the Electra alpha/beta scintillator.

Twenty soil samples taken from undisturbed background locations in the vicinity of the RCRSA were counted for one minute using the FIDLER. The mean FIDLER count rate for the 20 background soil samples was 418 counts per minute (cpm) with a standard deviation of 18.9 cpm. Therefore, the FSL was defined as $456 \mathrm{cpm}(418+(2 \times 18.9))$ at the RCRSA. However, on the first day of field operations the same FIDLER instrument background count rate was 477 cpm. Six new soil samples were then taken from a borehole located in a known undisturbed background location. Four of six soil samples exceeded the previously determined FSL of 456 $\mathrm{cpm}$. The FIDLER count rates for the background samples varied from $448 \mathrm{cpm}$ to $492 \mathrm{cpm}$ with a mean count rate of $472 \mathrm{cpm}$ and a standard deviation of $17.5 \mathrm{cpm}$. In the absence of any radiation sources, the FIDLER count rate varied from 413 to $477 \mathrm{cpm}$ on five different days during characterization activities at the RCRSA.

Data was obtained from the Soils Subproject on the FIDLER count rate of background soil samples. The data demonstrated that the daily variation in the response of the FIDLER instruments used during soils characterization was significant (DOE, 1996). The background count rate of the FIDLER varied from 32 to 56 percent. This variation is greater than the variation in the response of the FIDLER to the low energy gamma particles and photons emitted by the background concentration of radionuclides in soil.

\section{Recommendation}

The determination of the FSL for gross alpha and gross beta activity using the Electra should continue as originally planned. The process for determining the FSL for gross gamma activity using the FIDLER should be revised.

When site characterization only requires shallow surface soil measurements, five background locations should be marked, documented, and used daily to check the FIDLER response. If site 
characterization requires sampling of soil samples significantly below the surface, as is the case at the Double Tracks RADSAFE Area, then five soil samples from the background locations will be required to be retained. Whether background location or retained soil samples are used to determine the daily variations in the FIDLER response, the general method for calculating the daily FSL is the same. The method is described in the following paragraphs using, as an example, the retained soil samples.

It is recommended that five of the twenty background soil samples be retained for comparing instrument response on a daily basis. The five soil samples retained should include the two soil samples with the highest FIDLER count rate, the two soil samples with the lowest FIDLER count rates, and a soil sample with an average FIDLER count rate. These soil samples should be kept in a configuration like the soil samples taken during characterization, e.g., plastic bags. These five soil samples should be counted for one minute with the FIDLER each morning prior to characterization activities. The daily count rates, mean count rate and standard deviation of the mean count rate for these five soil samples should be calculated and documented. A daily FIDLER FSL should be calculated and documented for these five samples. If the daily FSL defers from the original FSL by more than one standard deviation, then the daily FSL should be used for that day and that day only. An example on how to determine the daily FIDLER FSL using hypothetical but realistic data is demonstrated below in Table 1 . 
Table 1. Examples of Daily FIDLER Count Rates for Calculating FSL

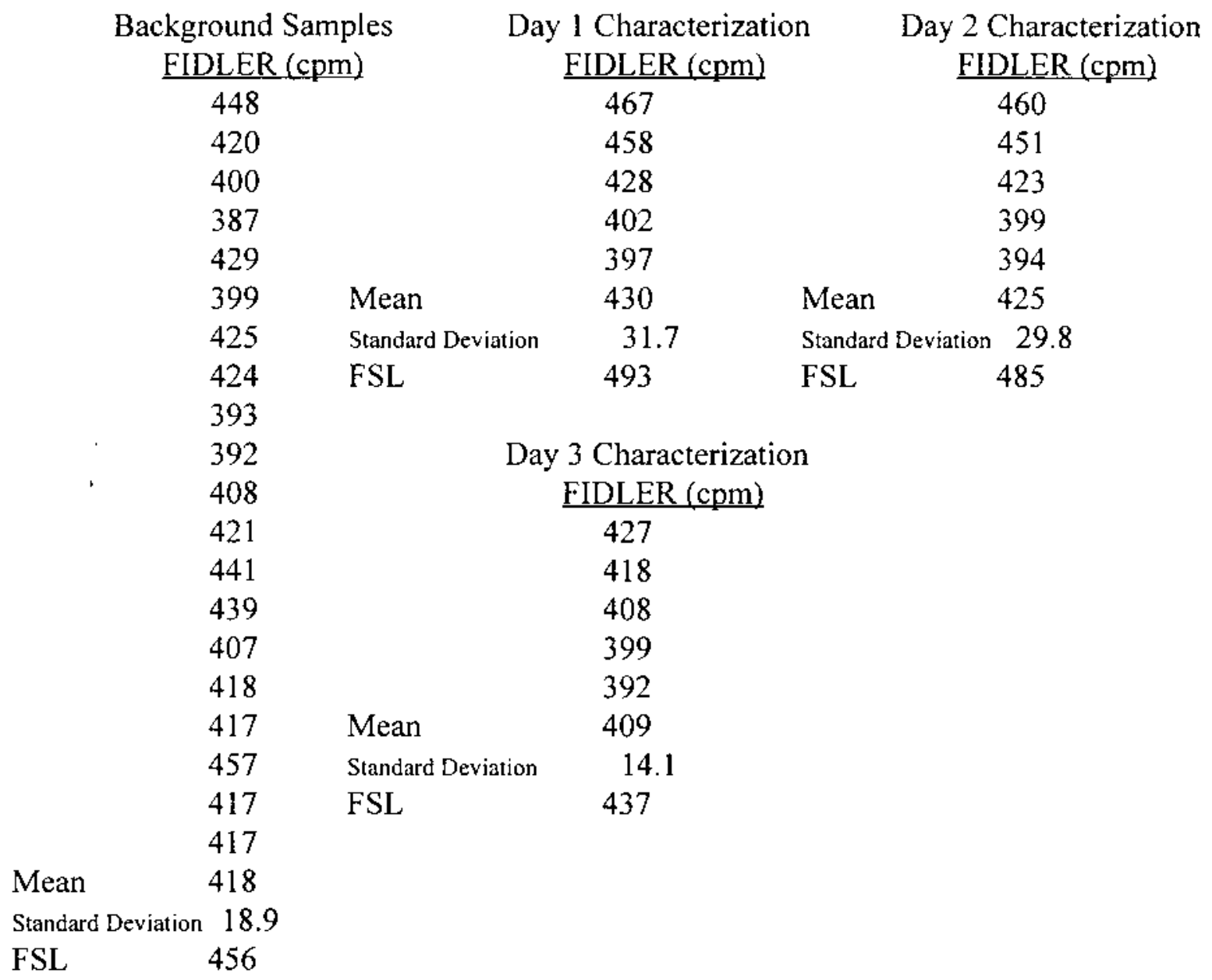

The gross gamma FSL derived from the 20 background soil samples was calculated to be 456 $\mathrm{cpm}$. Five soil samples out of the 20 were selected to be used as surrogate sources to evaluate the response of the FIDLER during characterization activities. The five samples selected corresponding to those giving the two highest FIDLER count rates, the two lowest count rates, and an average count rate. For this hypothetical background area the five soil samples were those that resulted in FIDLER cpm of 457, 448, 418, 392, and 387. During the first day of site characterization the FSL calculated using the five background soil samples was $493 \mathrm{cpm}$. The calculated FSL exceeds the FSL derived from the 20 background soil samples by greater than one standard deviation $(493-31.7=461$ which $>456)$. Therefore, in this example, during the first day of characterization the FSL of $493 \mathrm{cpm}$ should be used.

During the second day of characterization the daily FSL was calculated to be $485 \mathrm{cpm}$. This FSL is only slightly lower than the FSL calculated on the first day of characterization. However, the FSL calculated on the second day is not significantly larger than $456 \mathrm{cpm}$. The second day FSL

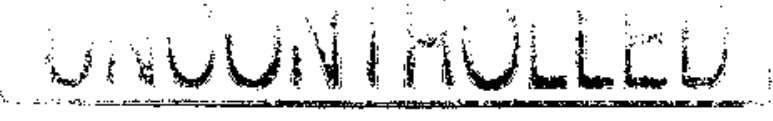


( $485 \mathrm{cpm}$ ) minus one standard deviation (29.5), is less than $456 \mathrm{cpm}$. Therefore, the gross gamma FSL during the second day of characterization remains at $456 \mathrm{cpm}$.

On the third day the gross gamma activity of the five background samples measured with the FIDLER resuits in an FSL of $437 \mathrm{cp}$. This is significantly less than the FSL measured for the 20 background samples. The FSL of $437 \mathrm{cpm}$ plus one standard deviation of $14.1 \mathrm{cpm}$ is $451 \mathrm{cpm}$. This count rate is less than $456 \mathrm{cpm}$. Therefore, on the third day of characterization the FSL is reduced to $437 \mathrm{cpm}$.

\section{Conclusion}

Health Physics recommends that daily FIDLER surveys of five background soil samples be performed. The mean and standard deviation of the FIDLER measurements and a field screen level should be calculated and documented. If the daily FIDLER field screening level differs by more than its standard deviation from the field screening level derived from the 20 background samples, then the daily FIDLER field screening should be used for that day. If the daily FIDLER field screening level differs by less than its standard deviation from the field screening level derived from the 20 background samples, than the original field screening level shall prevail. The use of daily FIDLER field screening levels ensures that gross gamma contamination in soil samples at the Double Tracks RADSAFE is detected.

If you have any questions or require any additional information please call me at 295-2031.

cc: Mike Foley

Mike O'Hagan

Charles Orchard

Laura Tryboski

Cheryl Rodriguez

Central File

\section{References}

AEC See U.S. Atomic Energy Commission

DOE See U.S. Atomic Energy Commission

U.S. Atomic Energy Commission 1964. Project Manager's Report, Project Roller Coaster, NVO 10. Nevada Operations Office. Las Vegas, NV.

U.S. Atomic Energy Commission 1996. Double Tracks Test Site Characterization Report. $D O E / N V-484$. Nevada Operations Office. Las Vegas, NV.

Knoll, G.F. 1979. Radiation Detection and Measurements. John Wiley \& Sons. New York, NY. 
Kocher, D. C. 1981. Radioactive Decay Data Tables. A Handbook of Decay Data for Application to Radiation Dosimetry and Radiological Assessments. Oak Ridge National Laboratory. Technical Information Center document DOE-TIC-11026. Springfield, VA. 


\section{NEVADA ENVIRONMENTAL RESTORATION PROJECT DOCUMENT REVIEW SHEET}

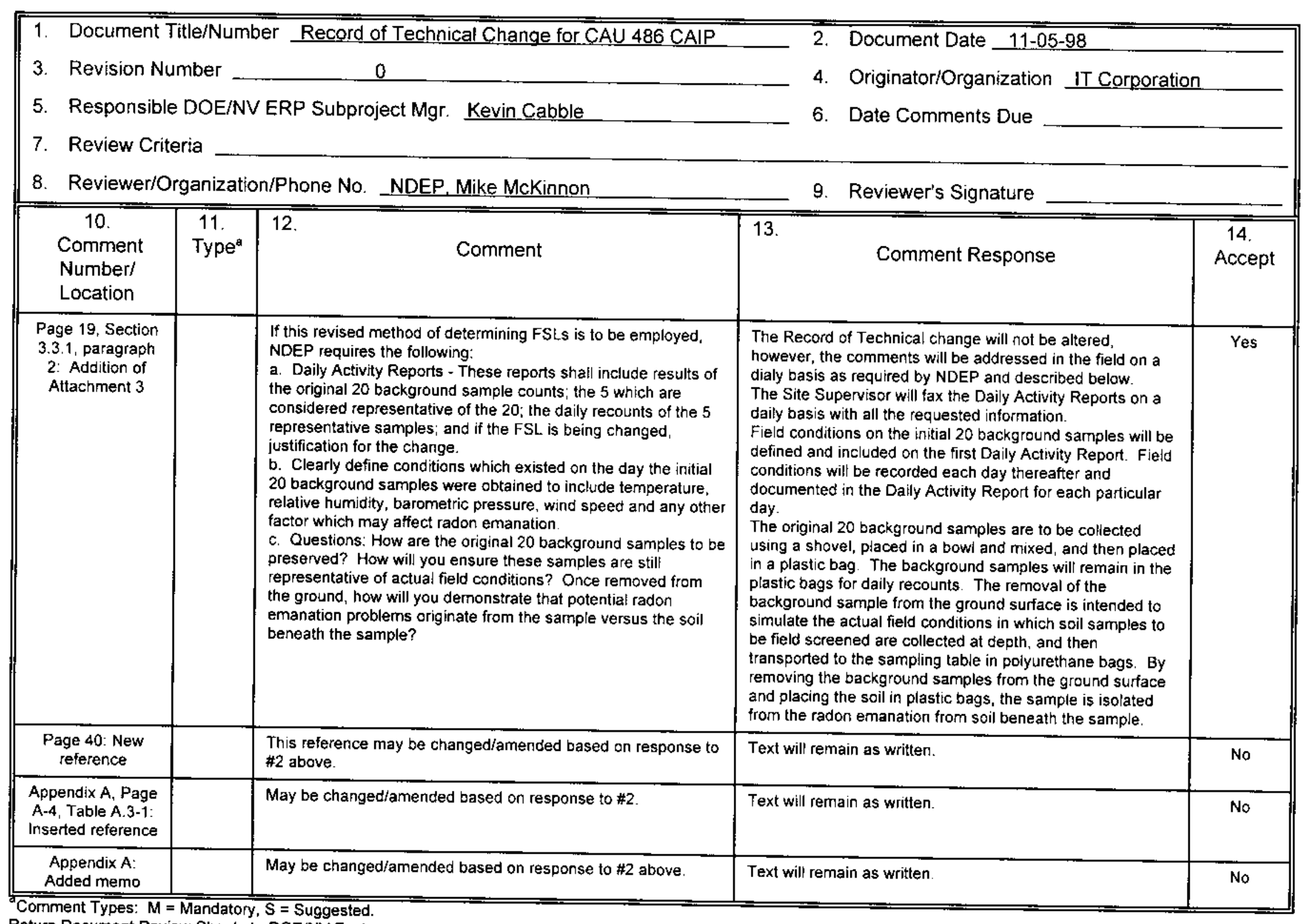

Return Docurnent Review Sheets to DOE/NV Environmental Restoration Division, Attn: QAC, M/S 505. 
Technical Change No.

The following technical changes (including justification) are requested by:

Cheryl L. Rodriguez
(Name)
Task Manager, Industrial Sites

(Title)

Changes to the Corrective Action Investigation Plan for CAU 486: Double Tracks RADSAFE Area, Nellis Air Force Range, Nevada, Rev. 0; DOE/NV-523

Page 25, Section 4.2, Par. 3: Insert the following sentence at the end of the third paragraph: Excavation activities for potential UXO will be conducted in accordance with IT Detailed Operating Procedures ITLV-TTR-006, Operating Procedures for Activities Involving Explosives and Unexploded Ordnance at the Tonopah Test Range (IT, 1996).

Page 27, Section 4.2, Par. 8: Replace the second, third, and fourth sentences with the following: During excavation, soil will be stockpiled as near the excavation as safely possible. The excavated soil will be placed on plastic sheeting if elevated field screening levels are obtained. Upon completion of characterization activities at the trench, the soil will be placed back into the excavation, and associated plastic sheeting will be containerized and labeled as "pending analysis."

Page 34, Section 5.3, Par. 1, second to last sentence: Change sentence to read: The final disposition of such wastes will be determined by evaluating the analytical results of acquired soil samples, or in the case of trenching, the disposition will be determined by evaluating field screening results.

Page 35, Section 5.3.1, Par. 1, last sentence: Revise the last sentence to read as follows: Analytical results from the swipe surveys will be used to determine if removable materials will be declared nonradioactive. Analytical results from soil sampling, or fieid screening levels in the case of trenching activities, will be used to determine if the materials will be declared sanitary.

Page 41, Section 7.0: Add the following reference:

IT Corporation, 1996, as amended. Detailed Operating Procedures, Tonopah Test Range, Industrial Sites. Las Vegas, NV.

The project time will be (Increased)(Decreased)(Unchanged) by approximately

$-0-$ days.

Applicable Project-Specific Document(s): Corrective Action Investigation Plan for Corrective Action Unit 486, Double Tracks RADSAFE Area, Nellis Air Force Range 7IN, Nevada, Rev. 0, DOE/NV--523

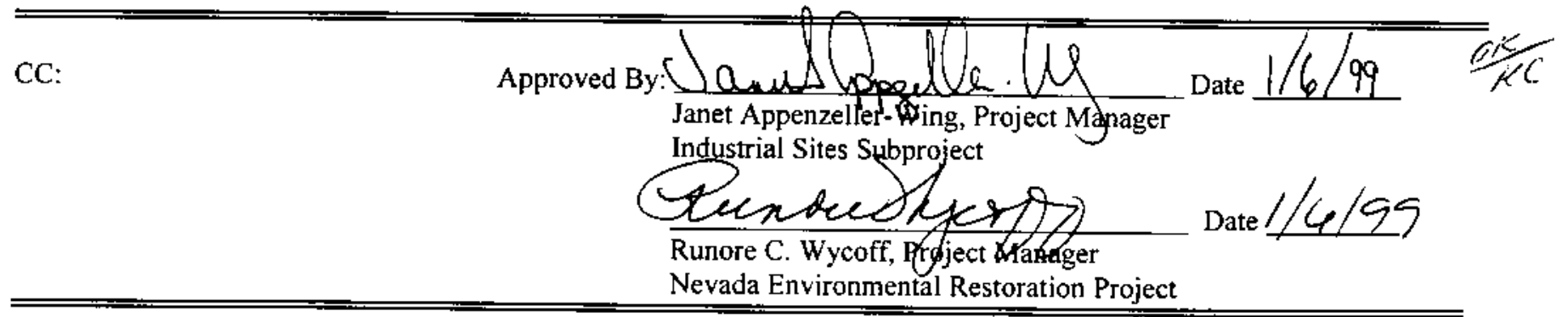




\section{Table of Contents}

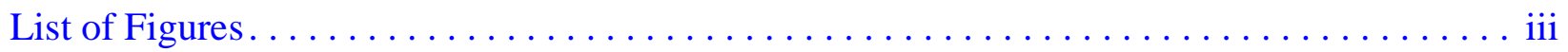

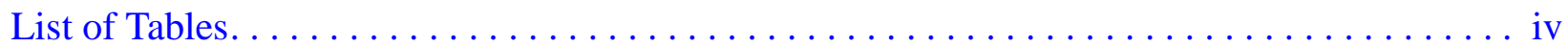

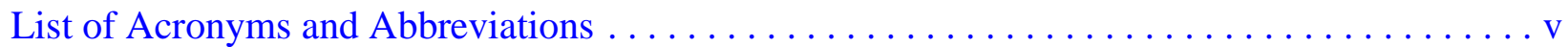

Executive Summary . . . . . . . . . . . . . . . . . . . . . . . ES-1

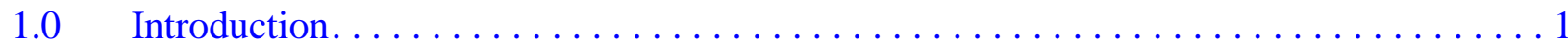

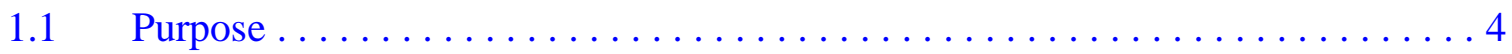

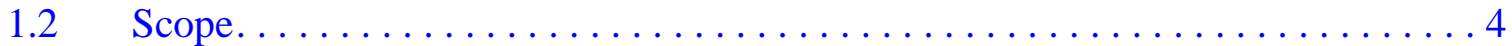

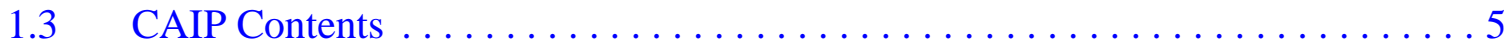

$2.0 \quad$ Facility Description. . . . . . . . . . . . . . . . . . 7

$2.1 \quad$ Physical Setting. . . . . . . . . . . . . . . . . . . . 7

2.2 Operational History. . . . . . . . . . . . . . . . . . . . . . 7

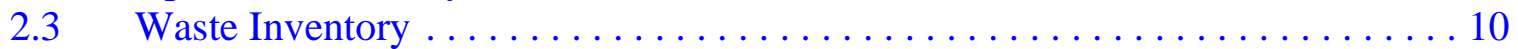

$2.4 \quad$ Release Information $\ldots \ldots \ldots \ldots \ldots \ldots \ldots \ldots \ldots \ldots \ldots \ldots \ldots \ldots \ldots \ldots$

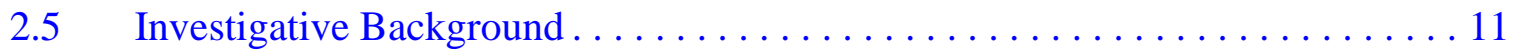

2.6 National Environmental Policy Act (NEPA) Requirements . . . . . . . . . . . . 16

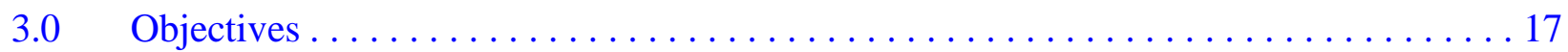

3.1 Conceptual Site Model . . . . . . . . . . . . . . . . . . 17

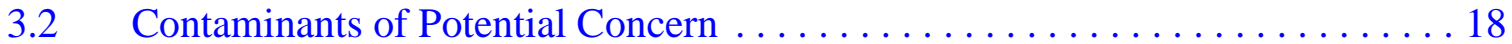

3.3 Preliminary Action Levels . . . . . . . . . . . . . . . . . . . . . . . . 18

3.3.1 Field Screening Levels . . . . . . . . . . . . . . . . . . . . 18

3.3.2 Chemical Preliminary Action Levels . . . . . . . . . . . . . . . . . . . 19

3.3.3 Radiological Preliminary Action Levels . . . . . . . . . . . . . . . . . . 19

3.4 DQO Process Discussion . . . . . . . . . . . . . . . . . . . . . 20

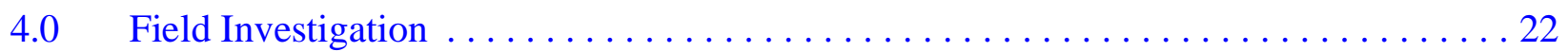

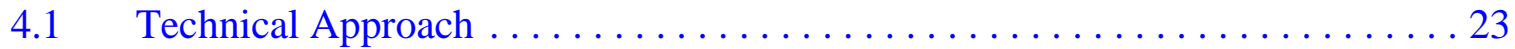

4.2 Excavation Activities . . . . . . . . . . . . . . . . . . . 23

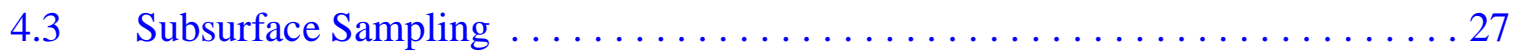

$4.3 .1 \quad$ Field Screening. . . . . . . . . . . . . . . . . . . . . . . 28

4.3.2 Sampling Criteria . . . . . . . . . . . . . . . . . . . . . . 29

4.4 Quality Control Samples. . . . . . . . . . . . . . . . . . . . . . . . . . 30

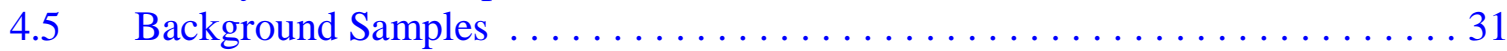

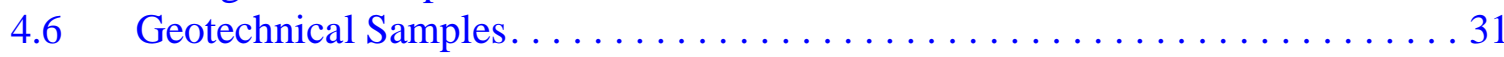

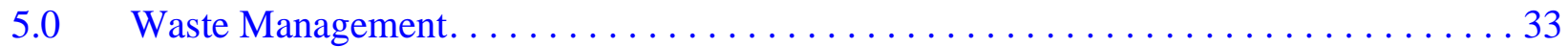

$5.1 \quad$ Waste Minimization . . . . . . . . . . . . . . . . . . . . . . . 33

$5.2 \quad$ Potential Waste Streams . . . . . . . . . . . . . . . . . . 34 


\section{Table of Contents (Continued)}

$5.3 \quad$ Investigation-Derived Waste Management $\ldots \ldots \ldots \ldots \ldots \ldots \ldots \ldots \ldots$

$5.3 .1 \quad$ Sanitary Wastes . . . . . . . . . . . . . . . . . . . . . 35

5.3.2 Low-Level Radioactive Waste . . . . . . . . . . . . . . . . . . 35

5.3 .3 Hazardous Waste . . . . . . . . . . . . . . . . . . . . . . . . . . 36

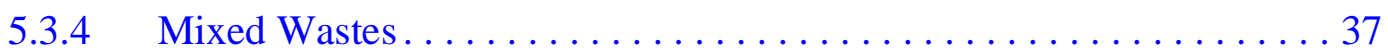

$6.0 \quad$ Duration and Records Availability . . . . . . . . . . . . . . . . . . . . . . . 39

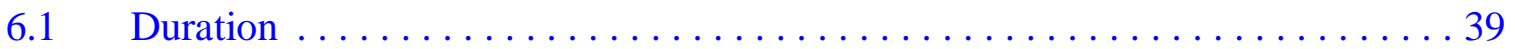

6.2 Records Availability. . . . . . . . . . . . . . . . . . . 39

$7.0 \quad$ References................................. 40

\section{Appendix A - Data Quality Objectives Process}

A.1.0 DQO Kickoff Meeting $\ldots \ldots \ldots \ldots \ldots \ldots \ldots \ldots \ldots \ldots \ldots \ldots \ldots \ldots \ldots$ A 1

A.2.0 Problem Statement . . . . . . . . . . . . . . . . . . . . . . . A-2

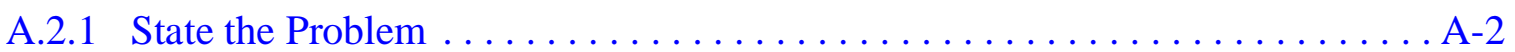

A.2.1.1 Problem to be Resolved ....................... A-2

A.2.1.2 Site History and Known or Suspected Sources of Contamination . . . A A-2

A.3.0 Conceptual Model. . . . . . . . . . . . . . . . . . . . . . . . . . A-3

A.3.1 Contaminants of Potential Concern $\ldots \ldots \ldots \ldots \ldots \ldots \ldots \ldots \ldots \ldots$

A.3.2 Conceptual Site Model . . . . . . . . . . . . . . . . . . . A-3

A.4.0 Decisions, Input, and Strategy $\ldots \ldots \ldots \ldots \ldots \ldots \ldots \ldots \ldots \ldots \ldots \ldots \ldots \ldots$

A.4.1 Decisions to be Resolved by the Investigation . . . . . . . . . . . . A-7

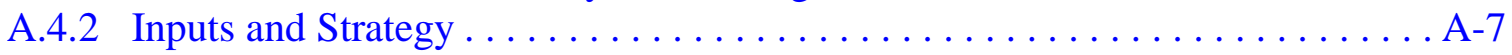

A.5.0 Decision Rules . . . . . . . . . . . . . . . . . . . . . . . . .

A.6.0 Decision Error. . . . . . . . . . . . . . . . . . . . . . A-10

A.7.0 Sampling Design. . . . . . . . . . . . . . . . . . . . . . . .

\section{Appendix B - Project Organization}

B.1.0 Project Organization . . . . . . . . . . . . . . . . . . 


\section{List of Figures}

Number

1-1 Nellis Air Force Range 71 North and Tonopah Test Range Location Map . . . . . . 2

1-2 Location of CAU 486, Double Tracks RADSAFE Area

Range 71 North, Nellis Air Force Range, Nye County, Nevada. . . . . . . . . . . . . 3

2-1 Potential Locations for the Areas of Concern at the DTRSA . . . . . . . . . 9

2-2 Double Tracks RADSAFE Area 1998 Geophysical Survey Location Map,

Nellis Range 71N, Nye County, Nevada. . . . . . . . . . . . . . . . . . . 12

2-3 EM-61 Survey for Area 2 and Area 6 at the DTRSA ................ 14

2-4 Area 6 Ground Penetrating Radar (GPR) Anomaly

DTRSA, Range $71 \mathrm{~N}$, Nye County, Nevada . . . . . . . . . . . . . . . . . 15

4-1 Proposed Trenching Lines. . . . . . . . . . . . . . . . . . . . . . . . . 24

4-2 Area 2 and Area 6 Geophysical Traverse Location Maps

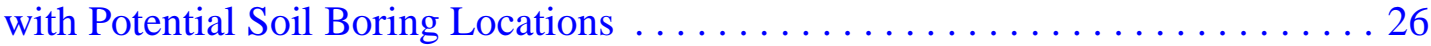

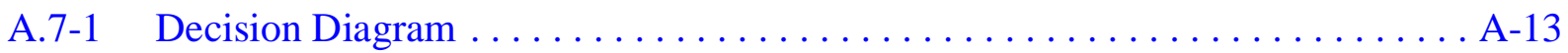

A.7-2 Proposed Trenching Locations $\ldots \ldots \ldots \ldots \ldots \ldots \ldots \ldots \ldots \ldots \ldots \ldots \ldots \ldots \ldots$

A.7-3 Possible Borehole Locations and Proposed Grid Area for Possible

Random Sampling . . . . . . . . . . . . . . . . . . A-16

A.7-4 Double Tracks RADSAFE Area CAS 71-23-001-71DT

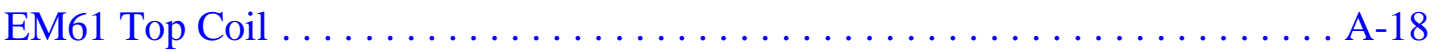

A.7-5 Double Tracks RADSAFE Area GPR Excavation Examples . . . . . . . . . . . A-19 


\section{List of Tables}

Number

3-1 Laboratory Analytical Requirements $\ldots \ldots \ldots \ldots \ldots \ldots \ldots \ldots \ldots \ldots \ldots$

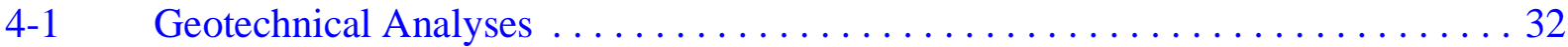

A.3-1 Contaminants of Potential Concern. . . . . . . . . . . . . . . A-4

A.3-2 Conceptual Model . ............................. A

A.4-1 Decision/Input Table for CAU $486 \ldots \ldots \ldots \ldots \ldots \ldots \ldots \ldots \ldots \ldots$ 


\section{List of Acronyms and Abbreviations}

\begin{tabular}{|c|c|}
\hline ALARA & As low as reasonably achievable \\
\hline $\mathrm{Am}$ & Americium \\
\hline bgs & Below ground surface \\
\hline CADD & Corrective Action Decision Document \\
\hline CAIP & Corrective Action Investigation Plan \\
\hline CAS & Corrective action site(s) \\
\hline CAU & Corrective action unit(s) \\
\hline COPC & Contaminant(s) of potential concern \\
\hline DOE & U.S. Department of Energy \\
\hline DOE/NV & U.S. Department of Energy, Nevada Operations Office \\
\hline DOT & U.S. Department of Transportation \\
\hline DQO & Data quality objective(s) \\
\hline DTRSA & Double Tracks RADSAFE Area \\
\hline DU & Depleted Uranium \\
\hline $\mathrm{EM}$ & Electromagnetic \\
\hline EPA & U.S. Environmental Protection Agency \\
\hline FFACO & Federal Facility Agreement and Consent Order \\
\hline FIDLER & Field instrument for the detection of low energy radiation \\
\hline $\mathrm{ft}$ & Foot (feet) \\
\hline $\mathrm{ft}^{2}$ & Square foot (feet) \\
\hline GPR & Ground-penetrating radar \\
\hline HASP & Health and safety plan \\
\hline IDW & Investigation-derived waste \\
\hline
\end{tabular}




\section{List of Acronyms and Abbreviations (Continued)}

IT

$\mathrm{km}$

LLW

$\mathrm{m}$

$\mathrm{m}^{2}$

MARSSIM

MEK

mi

$\mathrm{mg} / \mathrm{kg}$

$\mathrm{mg} / \mathrm{L}$

MS/MSD

NAC

NDEP

NEPA

NTS

NTSWAC

PAL

PCB

$\mathrm{pCi} / \mathrm{g}$

$\mathrm{pCi} / \mathrm{L}$

PPE

ppm

$\mathrm{Pu}$

PRG
IT Corporation

Kilometer(s)

Low-level radioactive waste

$\operatorname{Meter}(\mathrm{s})$

Square meter(s)

Multi-Agency Radiation Survey and Site Investigation Manual

Methyl ethyl ketone

Mile(s)

Milligram(s) per kilogram

Milligram(s) per liter

Matrix spike/matrix spike duplicate

Nevada Administrative Code

Nevada Department of Environmental Protection

National Environmental Policy Act

Nevada Test Site

Nevada Test Site Waste Acceptance Criteria

Preliminary action levels

Polychlorinated biphenyl(s)

Picocurie(s) per gram

Picocurie(s) per liter

Personal protective equipment

Part(s) per million

Plutonium

Preliminary Remediation Goal(s) 


\section{List of Acronyms and Abbreviations (Continued)}

QA/QC Quality assurance/quality control

QAPP Quality assurance project plan

RADSAFE Radiological safety

RCRA Resource Conservation and Recovery Act

SAIC Science Applications International Corporation

SSHASP Site-specific health and safety plan

SVOC Semivolatile organic compound(s)

TID Tamper-indicating device(s)

TPH Total petroleum hydrocarbon

TRU Transuranic

TTR Tonopah Test Range

VOC Volatile organic compound(s)

$\mu \mathrm{g} / \mathrm{L} \quad$ Microgram(s) per liter

UTM Universal Transverse Mercator

UXO Unexploded ordnance 


\section{Executive Summary}

The Corrective Action Investigation Plan for Corrective Action Unit (CAU) 486, the Double Tracks Radiological Safety (RADSAFE) Area, has been developed in accordance with the Federal Facility Agreement and Consent Order that was agreed to by the U.S. Department of Energy, Nevada Operations Office; the Nevada Division of Environmental Protection; and the U.S. Department of Defense. Corrective Action Unit 486 consists of a single Corrective Action Site, 71-23-001-71DT.

The Double Tracks RADSAFE Area was used during May 1963 to decontaminate vehicles, personnel, and animals from the Double Tracks experiment. The site is one of three areas identified as a potential location for disposal of radioactively contaminated material from the Double Tracks experiment. The other two locations are the Cactus Spring Waste Trenches (CAU 426) and the Roller Coaster RADSAFE Area (CAU 407), both of which have been investigated. Liquid wastes from the decontamination operations were drained from a gravel decontamination pad to a sump. The gravel associated with the decontamination pad was removed and placed in the sump, possibly with other solid waste and contaminated debris. Radioactively contaminated material associated with animal decontamination activities may have been disposed of in a pit historically referred to as the "animal burial pit." The sump and animal burial pit were backfilled.

Based on site history collected to support the Data Quality Objectives process, contaminants of potential concern for the site include plutonium, depleted uranium, methyl ethyl ketone, semivolatile organic compounds, and petroleum hydrocarbons. A conceptual site model for the Corrective Action Unit was developed as follows:

- Trench locations and boundaries for the decontamination facility and the animal burial pit are unknown. Historical investigations indicate that the vehicle and personnel decontamination area were located in the southern half of the site while the animal burial pit was located in the northern half.

- Contaminants of potential concern primarily associated with decontamination fluids were released into the soil at the decontamination facility (i.e., vehicle washdown pad, decontamination sump).

- Contaminants of potential concern in solid form were released into the soil primarily at the animal burial pit. 
- Post-shot radionuclide concentrations measured on the animal wagons stationed on the arc arrays are low. These concentrations are assumed to be worst case for radiological contamination at both the decontamination facility and animal burial pit.

- Lateral migration of contaminants of potential concern is limited to within the trench dimensions.

- Vertical migration of contaminants of potential concern is limited to less than 6 meters (20 feet) from the ground surface or 3 meters (10 feet) from the bottom of the trench.

- Intrusion by site personnel working on range may be a hazard because the site is not posted with signs nor restricted by fences. Because of this, the potential for exposure to contaminated soil or to buried waste exists.

- Environmental conditions (i.e., arid climate) and depth to groundwater (250-270 meters) at the site make impact to groundwater by downward migration of contaminants of potential concern highly unlikely.

- There is a potential for surface water runoff to expose buried waste, if present, during significant rainfall events because drainage patterns on the alluvial fan surface dissect parts of the site in which the trenches are believed to exist.

A more detailed conceptual site model is presented in Section 3.0 of this investigation plan. The conceptual model serves as the basis for the sampling strategy.

The technical approach for investigating this CAU consists of the following activities:

- Excavation of proposed trenching lines to delineate the site boundaries of the decontamination facility and animal burial pit

- Subsurface biased sampling within identified site boundaries using soil borings

- Subsurface random sampling if site boundaries cannot be identified for the decontamination facility

Field screening methods will be used to detect preliminary concentrations of volatile organics and radionuclides. Samples will be collected for laboratory analysis from within each site boundary. Additional sampling and analytical details are presented in Section 4.0 of the Corrective Action Investigation Plan. Details of the waste management strategy for the CAU are included in Section 5.0 of the investigation plan. 
Under the Federal Facility Agreement and Consent Order, the Corrective Action Investigation Plan will be submitted to the Nevada Department of Environmental Protection for approval. Field work will be conducted following approval of the plan. The results of the field investigation will support a defensible evaluation of corrective action alternatives in the Corrective Action Decision Document. 


\subsection{Introduction}

This Corrective Action Investigation Plan (CAIP) has been developed in accordance with the Federal Facility Agreement and Consent Order (FFACO) that was agreed to by the U.S. Department of Energy, Nevada Operations Office (DOE/NV); the State of Nevada Division of Environmental Protection (NDEP); and the U.S. Department of Defense (FFACO, 1996). The CAIP is a document that provides or references all of the specific information for investigation activities associated with Corrective Action Units (CAUs) or Corrective Action Sites (CASs). According to the FFACO, CASs are sites potentially requiring corrective action(s) and may include solid waste management units or individual disposal or release sites (FFACO, 1996). Corrective Action Units consist of one or more CASs grouped together based on geography, technical similarity, or agency responsibility for the purpose of determining corrective actions.

This CAIP contains the environmental sample collection objectives and the criteria for conducting site investigation activities at CAU 486, the Double Tracks Radiological Safety (RADSAFE) Area (DTRSA) which is located on the Nellis Air Force Range 71North (N), west of the Tonopah Test Range (TTR). The TTR, included in the Nellis Air Force Range Complex, is approximately 255 kilometers $(\mathrm{km})$ (140 miles [mi]) northwest of Las Vegas, Nevada (Figure 1-1). Corrective Action Unit 486 is comprised of CAS 71-23-001-71DT consisting of two areas of concern referred to as the vehicle decontamination area and the animal burial pit.

The DTRSA is located on the west side of the Cactus Range approximately $8 \mathrm{~km}(5 \mathrm{mi})$ southwest of the Cactus Spring gate at the intersection of the Cactus Spring Road and the Double Tracks Control Point Road (Figure 1-2). The DTRSA was used during May 1963 to decontaminate vehicles, equipment, personnel, and animals from the Double Tracks test. The DTRSA is one of three areas identified as a potential location for the disposal of radioactively contaminated materials from the Double Tracks experiment. The other two locations are the Cactus Spring Waste Trenches (CAU 426) and the Roller Coaster RADSAFE Area (CAU 407), both of which have been investigated. The surface and subsurface soils are likely to have been impacted by plutonium and other contaminants of potential concern (COPCs) associated with decontamination activities at this site. 


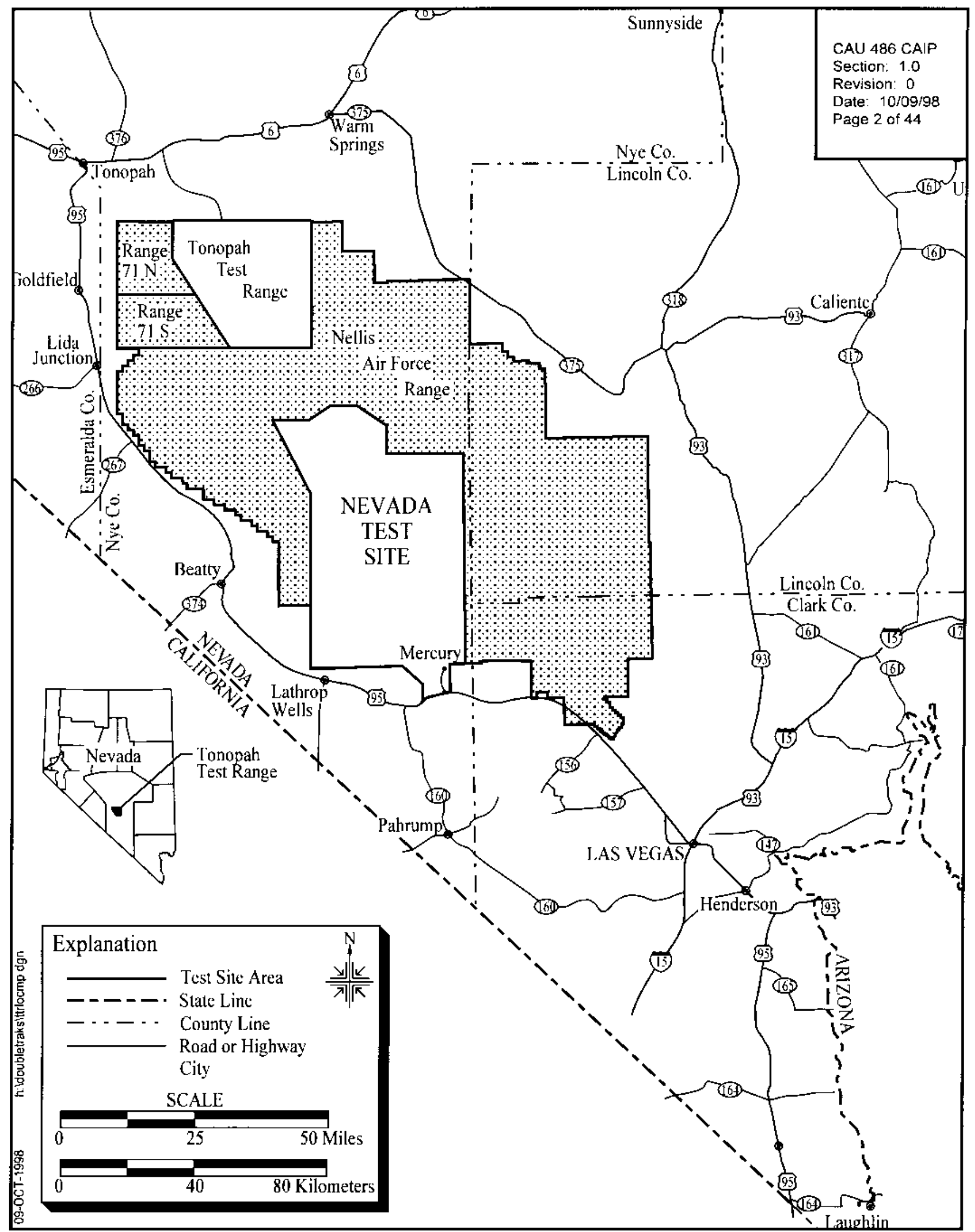

Figure 1-1

Nellis Air Force Range 71 North and Tonopah Test Range Location Map 

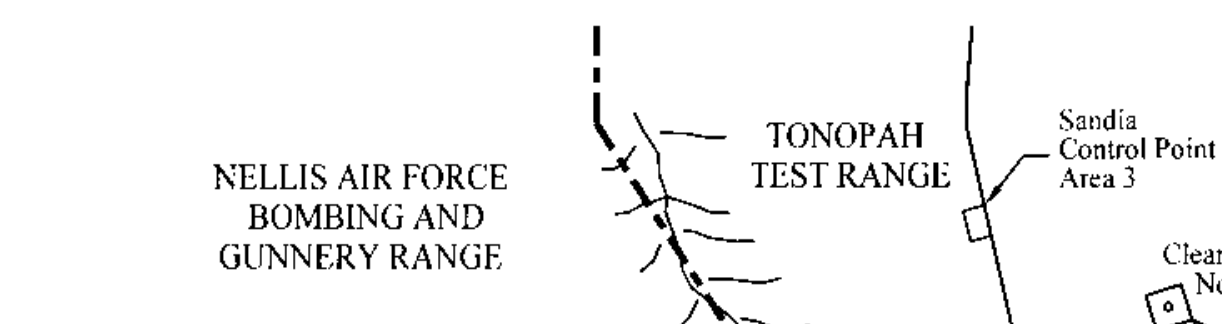

CAU 486 CAIP

Section: 1.0

Revision: 0

Date: $10 / 09 / 98$

Page 3 of 44
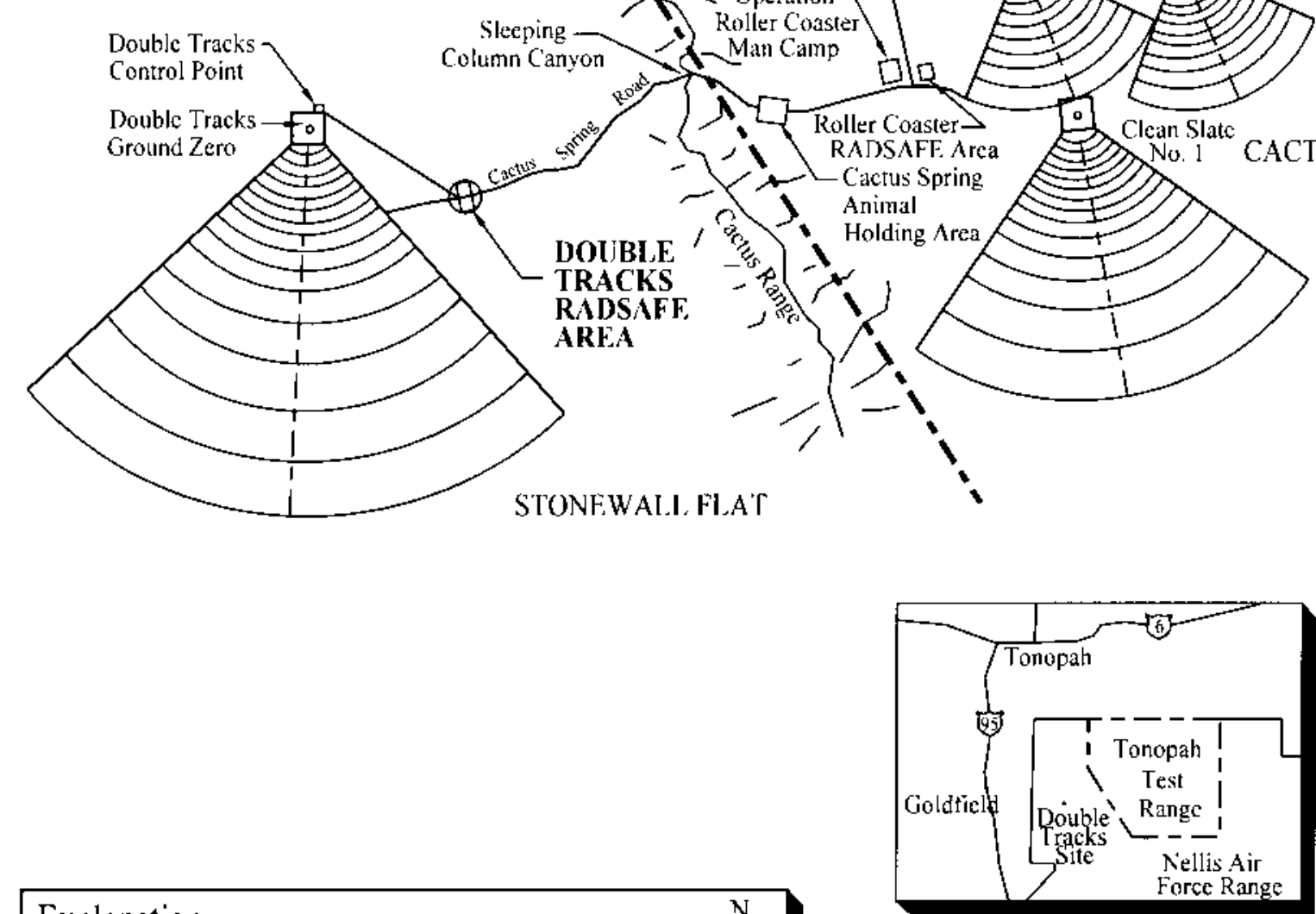

Explanation

- - Tonopah Test Range Boundary

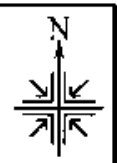

Note

Size of arc arrays are not to scale and do not reflect actual areas of contamination that resulted from Double Tracks and Clean Slate tests.

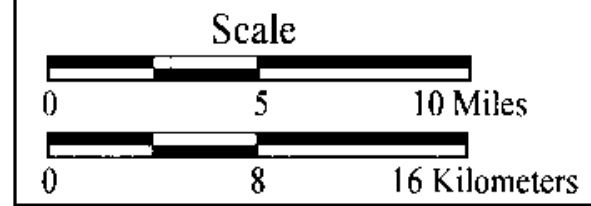

Source: Modified from Burnett et al., 1964

Figure 1-2

Location of CAU 486, Double Tracks RADSAFE Area Range 71 North, Nellis Air Force Range, Nye County, Nevada 


\subsection{Purpose}

This CAIP presents a plan to investigate the DTRSA where unregulated disposal of radioactive and possibly hazardous waste occurred during decontamination activities for the Double Tracks test. The purpose of the corrective action investigation described in this CAIP is to:

- Identify and verify the locations of the decontamination facility and animal burial pit within the DTRSA.

- Identify the presence and nature of COPCs.

- $\quad$ Determine the vertical and lateral extent of COPCs.

- Provide sufficient information and data to develop and evaluate appropriate corrective actions for the CAS.

This CAIP was developed using the U.S. Environmental Protection Agency (EPA) Data Quality Objectives (DQOs) (EPA, 1994d) process to clearly define the goals for collecting environmental data, to determine data uses, and to design a data collection program that will satisfy these uses. A DQO scoping meeting was held prior to preparation of this plan; a brief summary of the DQOs is presented in Section 3.4. A more detailed summary of the DQO process and results is included in Appendix A.

\subsection{Scope}

The scope of this CAIP is to resolve the problem statement identified in the DQO process (see Appendix A). This problem entails the disposal of radioactive and possibly hazardous wastes at the DTRSA, and existing data are insufficient to support selection of a corrective action for the CAU. Therefore, the scope of the corrective action investigation at the DTRSA includes the following tasks that must be accomplished to answer the problem statement:

- Conduct excavation activities to identify and verify the boundary locations of the vehicle decontamination (decon) facility and the animal burial pit.

- Drill boreholes using a sonic drilling method or other suitable methods capable of reaching the expected vertical extent of COPCs, of penetrating potential subsurface geologic and project related anomalies (e.g., caliche, gravel, or buried waste), and of providing suitable core for sample collection and logging of subsurface conditions. 
- Conduct field screening to direct drilling and sampling activities and provide an initial assessment of the subsurface conditions. Potential limitations in field screening capabilities for radionuclides will be addressed through laboratory analysis.

- Collect soil samples for laboratory analysis of environmental and geotechnical parameters.

- Log core to assess soil and waste characteristics.

\subsection{CAIP Contents}

Section 1.0 of this CAIP provides an introduction to this project, including the purpose and scope for this corrective action investigation. The remainder of the document details the investigation strategy and complies with FFACO (1996) requirements that CAIPs address the following elements:

- Management

- Technical aspects

- Quality assurance

- Health and safety

- Public involvement

- Field sampling

- Waste management

The managerial aspects of this project are discussed in the DOE/NV Project Management Plan (DOE/NV, 1994b) and the site-specific Field Management Plan that will be developed prior to field activities. A facility description is presented in Section 2.0. The technical aspects of this CAIP are contained in Section 3.0 and Section 4.0 of this document and in the DQO summary presented in Appendix A. Also discussed in Section 4.0 are the field sampling activities and general health and safety concerns. General field and laboratory quality assurance and quality control (QA/QC) issues, including collection of QC samples, are presented in the Industrial Sites Quality Assurance Project Plan (QAPP) (DOE/NV, 1996d); the methods for field QA/QC are discussed in approved procedures. The generic health and safety aspects of this project are discussed in the Environmental Restoration Project Health and Safety Plan (HASP) (DOE/NV, 1996b) and will also be supplemented with a site-specific HASP (SSHASP) written prior to the start of field work. No CAU-specific public involvement activities are planned at this time; however, an overview of public involvement is documented in the "Public Involvement Plan" in Appendix V of the FFACO (1996). Waste management issues are discussed in Section 5.0. The project schedule and records availability 
information for this CAIP are discussed in Section 6.0, and Section 7.0 provides a list of project references. 


\subsection{Facility Description}

\subsection{Physical Setting}

The DTRSA is an area of disturbed ground located in Stonewall Flat on the Nellis Air Force Bombing Range $71 \mathrm{~N}$ west of the TTR. The site is approximately $8 \mathrm{~km}(5 \mathrm{mi})$ southwest of the Cactus Spring gate at the intersection of the Cactus Spring Road and the Double Tracks Control Point Road. The entire disturbed area is approximately 210 meters $(\mathrm{m})$ by $120 \mathrm{~m}$ (700 feet [ft] by $400 \mathrm{ft})$. The areas of concern are not fenced or posted. The site is bounded by high desert on all sides. The Cactus Spring Road dissects the site into northern and southern halves.

The DTRSA lies near the northern end of Stonewall Flat on an alluvial fan that slopes westward from the Cactus Range. The elevation at the site is approximately 1,658 $\mathrm{m}(5,440 \mathrm{ft})$ above sea level (DOE/NV, 1996a). The depth to water below ground surface (bgs) is unknown, but is estimated to be approximately 250 to $270 \mathrm{~m}$ (820 to $890 \mathrm{ft}$ ) with an estimated general flow direction of southwest (DOE/NV, 1996a).

The site is comprised of disturbed soils with sparse vegetation. The near-surface alluvium at the site has never been studied in detail; however, it is likely to be similar to alluvial fans within the basin and range, consisting of boulders, cobbles and coarse gravel grading to sand typically covered by a thin, fine, loamy soil unit (DOE/NV, 1996a).

Two factors could potentially result in exposure of the buried waste within the areas of concern. Currently, drainage patterns for surface water runoff resulting from significant rainfall events dissect the DTRSA and may represent an exposure hazard in the future. Secondly, the site lies within an active bombing range where wayward artillery may impact the site and potentially expose the areas of concern. These factors will be taken into consideration for future corrective actions.

\subsection{Operational History}

Project Roller Coaster consisted of four noncritical tests of a nuclear device: Double Tracks and Clean Slates 1, 2, and 3. The Clean Slate tests were conducted at Cactus Flat located within the boundaries of the TTR. The Double Tracks test was conducted in Stonewall Flat, approximately 
$32 \mathrm{~km}$ (20 mi) east of Goldfield, Nevada, located on the Nellis Air Force Range (REECo, 1964). The Clean Slate tests used a total of 3 devices containing plutonium and 44 devices without plutonium, containing DU only. The Double Tracks test used a single device containing plutonium and DU and was designed to investigate the characteristics of plutonium-bearing particulate material formed by the nonnuclear detonation of a nuclear weapon. The experiment exposed approximately 300 animals consisting of dogs, sheep, and burros to respirable concentrations of plutonium and uranium to assess the inhalation uptake of these radionuclides (REECo, 1964). Muslin shrouds were used to cover the 300 animals during the detonation to prevent airborne contamination from contacting major portions of the animals' bodies. Immediately following the test, the muslin shrouds were removed from the animals, and approximately 18 of these animals were sacrificed and skinned (Wilson and Terry, 1965).

All facilities associated with the DTRSA operation were removed. Based on available information, the assumed areas of concern at the DTRSA consist of the decontamination facility (vehicle decon pad and decon sump) in the southern half of the DTRSA, and an animal burial pit located in the northern half. Radioactive waste possibly containing other COPCs was discharged and/or buried here as part of the decontamination operations. Figure 2-1 outlines the approximate areal dimensions which will be investigated for the decontamination facility and the animal burial pit.

Available historical information on vehicle and personnel decontamination operations for the DTRSA is limited. These decon operations are assumed to be similar to the Roller Coaster RADSAFE operations (DOE/NV, 1998a). Based on historical photos and documentation, the decontamination facility included a hotline area for doffing anti-contamination clothing and personal protective equipment (PPE); a vehicle decon area consisting of a vehicle decon pad, a sump, and a water tank; and possibly a waste disposal pit. The vehicle decon pad was filled with gravel to serve as a french drain for vehicle decon water. Former site employees indicate that the area associated with the vehicle decon was a bulldozed trench approximately 120 square yards in area (Penwell, 1995). Historic photos suggest the trench may be as wide as 6 to $9 \mathrm{~m} \mathrm{(20} \mathrm{to} 30 \mathrm{ft})$ and is elongated parallel to Cactus Spring Road. After operations, the gravel associated with the french drain was likely removed and placed in the sump, possibly with other solid waste and contaminated debris resulting from field operations. 


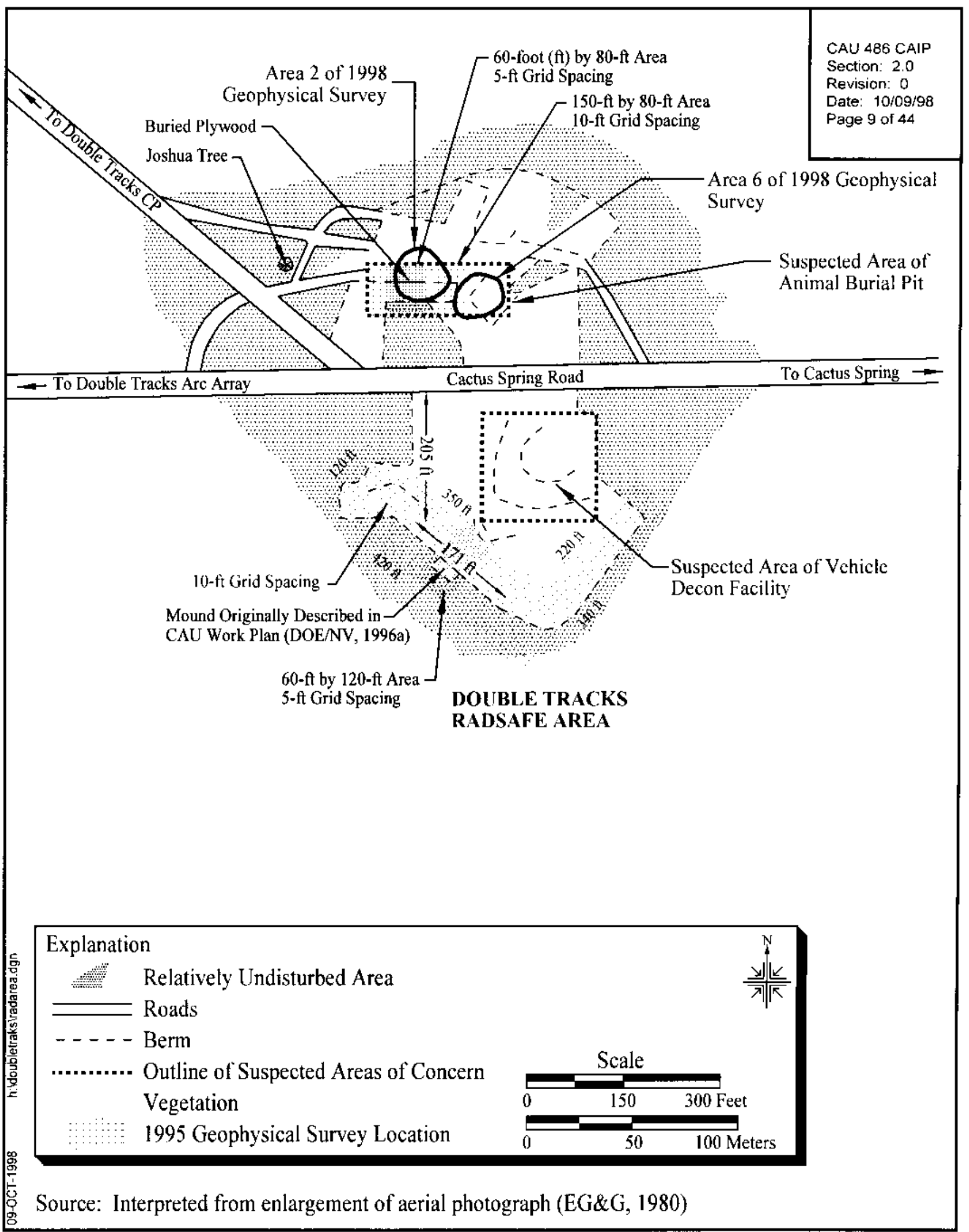

Figure 2-1

Potential Locations for the Areas of Concern at the DTRSA 
Available historical information indicates that animal decontamination activities for the DTRSA included removal of the muslin shrouds used during the test immediately after the animals were retrieved from the test area, skinning the 18 sacrificed animals, and removing exposed limbs of the sacrificed animals (Wilson and Terry, 1965). Reportedly, the doffed shrouds, hides, and amputated limbs were buried in an animal burial pit (Wilson, 1995a, 1995b; Shugart, 1995). This burial pit is believed to be located on the north side of the DTRSA. No information exists about an animal decon pad. The animal burial pit has been described as approximately 2 to $3 \mathrm{~m}$ (6 to $10 \mathrm{ft}$ ) deep, 1.8 to $2.4 \mathrm{~m}$ (6 to $8 \mathrm{ft})$ wide, and 9 to $12 \mathrm{~m} \mathrm{(30} \mathrm{to} 40 \mathrm{ft}$ ) long (Wilson, 1995a).

Although the disturbed area of the DTRSA is clearly discernible at ground-level today, and historically in aerial and surface photos, there is currently little evidence for the exact locations of either the decon facility or the animal burial pit. Both areas have been covered with several feet of clean earth, making identification of the areas of concern difficult. The CAU Work Plan for TTR (DOE/NV, 1996a) describes two potential trench areas where IT Corporation conducted geophysical surveys in 1995 (IT, 1995). The surveyed areas are outlined in Figure 2-1. Through additional photo interpretation, recent geophysical surveys, and physical evidence, only the area on the north side is strongly believed to represent a potential trench area. This area contains the partially exposed plywood and metallic posts at the ground surface and is believed to represent a portion of the animal burial pit (see Figure 2-1). Section 2.5 offers a more detailed discussion of additional locations identified for both areas.

\subsection{Waste Inventory}

The length of operations at the DTRSA is unknown but operations were probably of a short duration because the DTRSA only supported the single Double Tracks test. The volumes and types of hazardous waste disposed at the site were not documented; however, the volumes of waste can be assumed to be lower than those disposed of at the Roller Coaster RADSAFE Area (DOE/NV, 1998a) which supported an increased number of tests, personnel, and vehicles associated with Clean Slate tests. Interviews indicate that methyl ethyl ketone (MEK) from the decontamination of facemasks used during the Double Tracks experiment may have been disposed of in one of the DTRSA trenches (Sygitowicz, 1998). Lead-acid batteries are not assumed to be disposed of at the DTRSA, but rather would have been reused during the Clean Slate tests. 


\subsection{Release Information}

The COPCs were released directly to the soils of the DTRSA as a result of personnel, vehicle, and animal decontamination and waste burial. Subsurface COPCs are a result of direct release to the soil and subsequent migration through natural processes. Migration is assumed to be minor due to the arid climate and high evaporation. Exact quantities of liquids released to the DTRSA are unknown. Interviews indicate that approximately 300 muslin shrouds contaminated with plutonium were most likely buried in the animal burial pit at DTRSA. The exact amount and type of other contaminated debris and solid waste disposed in the sump or animal burial pit are unknown.

\subsection{Investigative Background}

No surface or subsurface sampling has been conducted at the DTRSA to date. A surface radiological survey of the DTRSA was performed in March 1998 by Science Applications International Corporation (SAIC) for IT Corporation (IT) to identify any locations of surface contamination and show radiological trending information. The results of the survey demonstrate that there is no beta-gamma activity elevated above background on the surface soil of the DTRSA (Adams, 1998b).

Geophysical surveys conducted at the site in 1995 by IT (IT, 1995) included an electromagnetic (EM) and magnetometer survey. A rectangular area of 1,115 square meters $\left(\mathrm{m}^{2}\right)\left(12,000\right.$ square feet $\left.\left[\mathrm{ft}^{2}\right]\right)$ was surveyed on the north side of the DTRSA. This area corresponds to Area 2 of the 1998 geophysical investigation (Figure 2-1). In addition, an L-shaped area of 6,112 $\mathrm{m}^{2}\left(65,800 \mathrm{ft}^{2}\right)$ was surveyed on the south side of the DTRSA. This area corresponds to Area 5 of the 1998 geophysical investigation (Figures 2-1 and 2-2). Based on the geophysical survey results, it is apparent that the southern survey area contains no metallic anomalies or trench-like characteristics. The surveyed area on the north contains excessive interference from the metal posts in the ground such that the presence of buried material could not be identified.

Additional geophysical investigations (SAIC, 1998) were conducted by SAIC for IT in March 1998. The geophysical investigation included an EM-31 survey over the entire disturbed area of the DTRSA covering approximately $59,450 \mathrm{~m}^{2}\left(640,000 \mathrm{ft}^{2}\right)$. Areas with the visual appearance of disturbance and areas of EM-31 anomalies were further evaluated using ground-penetrating radar (GPR) and a high resolution metal detector (EM-61). Figure 2-2 is a geophysical survey location 


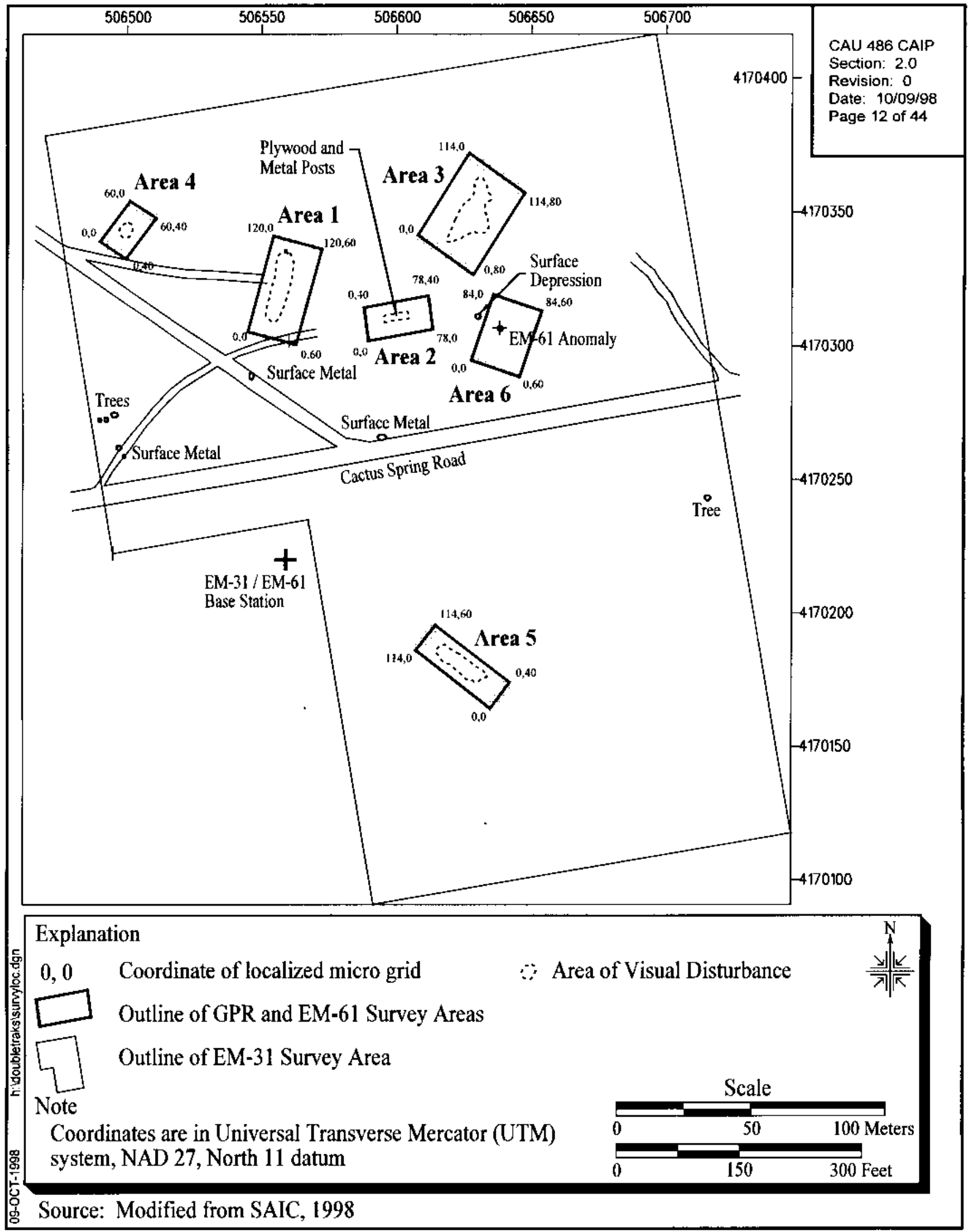

Figure 2-2

Double Tracks RADSAFE Area 1998 Geophysical Survey Location Map, Nellis Range 71N, Nye County, Nevada 
map of the DTRSA and relative cultural features identified during the 1998 surveys. The figure depicts both the EM-31 survey area and the six localized GPR and EM-61 survey areas.

The EM-31 survey revealed only one anomaly located within the suspect area of the animal burial pit. This area is not associated with any type of surface disturbance thought to be related to excavation or disposal. The partially exposed plywood and metal posts did not register as an anomalous area due to a weak signal on the EM-31.

The GPR and EM-61 surveys, conducted on the six localized areas, identified significant anomalies in Areas 2 and 6 only (Figures 2-2 and 2-3). Area 2 corresponds to the partially exposed plywood and metal posts visible at the ground surface. Interpretation of GPR data suggests that the depth of disturbed soil in Area 2 is less than $2 \mathrm{~m}(6 \mathrm{ft})$. Area 6 corresponds to the anomaly identified by the EM-31 survey. Area 6 GPR data (Figure 2-4) suggests that disturbed soil/buried material appears to reach a depth of $3 \mathrm{~m}(10 \mathrm{ft})$. The shape of the GPR anomaly boundary suggests an excavation and exhibits reflector patterns similar to those found in landfill settings. Both Area 2 and Area 6 will be investigated as possible locations of the animal burial pit as shown on Figure 2-1. Although surface debris exists at Area 2 to suggest the presence of a buried trench, and reflector patterns in the Area 6 GPR data resemble, and are interpreted as landfill setting reflector patterns, the possibility exists that the Area 2 and 6 anomalies may be buried ordnance associated with historic and current activities of the bombing range.

Due to the lack of surface expression and geophysical evidence, locating the vehicle decon pad and sump required evaluation of other sources of information. Those sources included the review of historical documentation, interviews with former site workers, and inspection of historic photographs (i.e., surface and aerial photographs). Based on these sources, it is believed the vehicle decon area was situated, at a minimum, 9 m (30 ft) south of the Cactus Spring Road to allow room for the personnel decon area. The long axis of the vehicle decon area was oriented parallel to the Cactus Spring Road and had a width of approximately 6 to $9 \mathrm{~m} \mathrm{(20} \mathrm{to} 30 \mathrm{ft}$ ). An area interpreted as representing the approximate location of the vehicle decon pad and sump is shown in Figure 2-1. 


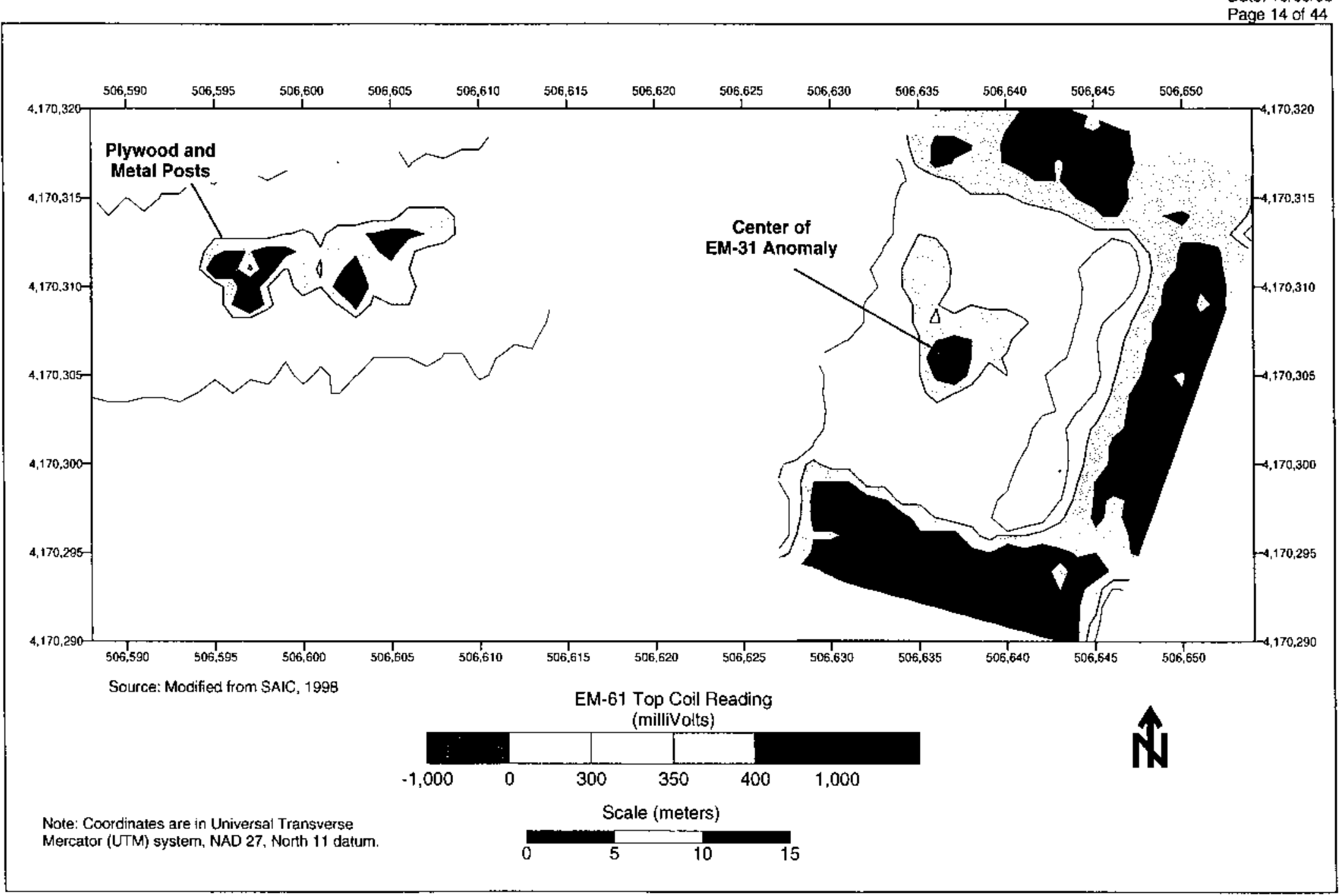

Figure 2-3

EM-61 Survey For Area 2 and Area 6 at the DTRSA 


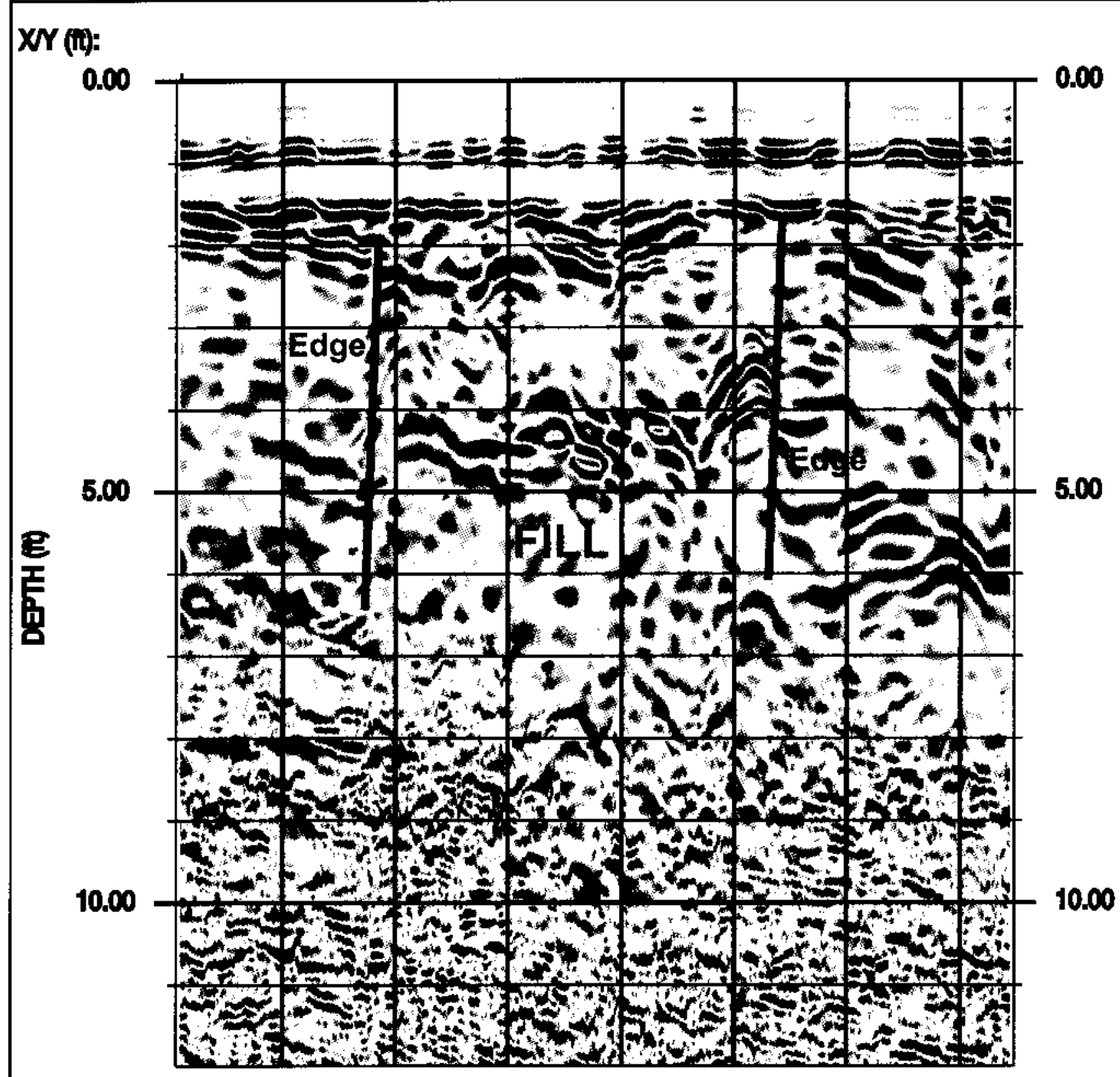

Source: Modified from SAIC, 1998

Refer to Figure 4-2 for location of traverse lines in Area 6.

Figure 2-4

Area 6 Ground Penetrating Radar (GPR) Anomaly

DTRSA, Range $71 \mathrm{~N}$, Nye County, Nevada 


\subsection{National Environmental Policy Act (NEPA) Requirements}

In accordance with the DOE/NV NEPA compliance program, a NEPA checklist shall be completed prior to commencement of site investigation activities at CAU 486. This checklist compels DOE/NV projects to evaluate their proposed project against a list of several potential environmental impacts. These include, but are not limited to, air quality, chemical use, waste generation, noise level, and land use. Completion of the checklist results in a determination of the appropriate level of NEPA documentation by the DOE/NV NEPA Compliance Officer. 


\subsection{Objectives}

The DQOs are qualitative and quantitative statements that specify the quality of the data required to support potential courses of action for the DTRSA. The DQOs were developed to clearly define the purposes for which environmental data will be used and to design a data collection program that will satisfy these purposes. One element of the DQO process is the formulation of a conceptual site model.

\subsection{Conceptual Site Model}

The conceptual site model defines the expected nature and extent of contamination at the DTRSA. The conceptual site model for the DTRSA is based on assumptions formulated on information presented in Section 2.0 and discussed during the DQO process. The model is used to identify appropriate sampling strategy and data collection methods. The conceptual site model and assumptions for the DTRSA developed in the DQO process are presented in Appendix A and are summarized as follows:

- Well-defined trench locations and boundaries for the decon facility and the animal burial pit are unknown. Historical investigations indicate that the vehicle and personnel decon area were located in the southern half of the DTRSA while the animal burial pit was located in the northern half.

- COPCs primarily associated with decon fluids were released into the soil at the decon facility (i.e., vehicle washdown pad and sump trench).

- COPCs in solid form (i.e., contaminated materials) were released into the soil primarily at the animal burial pit.

- Post-shot radionuclide concentrations measured on the animal wagons stationed on the arcs are low (microgram quantities) (Wilson, 1995b). These concentrations are assumed to be worst case for radiological contamination at both the decon facility and animal burial pit.

- Lateral migration of COPCs is limited to within the trench dimensions.

- Vertical migration of COPCs is limited to less than $6 \mathrm{~m}(20 \mathrm{ft})$ from the ground surface or $3 \mathrm{~m}$ $(10 \mathrm{ft})$ from bottom of trench. 
- Original test device contained plutonium in metal form and depleted uranium reportedly in the form of oxides (Adams, 1998a).

- Plutonium and depleted uranium contamination are expected to be in the form of oxide, mixed oxides, silicates, carbides, and carbonates (Perry et al., 1966; Sherwood, 1966).

- Intrusion by U.S. Air Force personnel working on range may be a hazard because the site is not posted with signs or restricted by fences. Because of this, the potential for exposure to personnel from contaminated soil or buried waste exists.

- Environmental conditions (i.e., arid climate) and depth to groundwater (250 to $270 \mathrm{~m}$ [820 to $890 \mathrm{ft}$ ]) at the site make impact to groundwater by downward migration of COPCs highly unlikely.

- Current drainage patterns on the alluvial fan surface dissect parts of the DTRSA in which the areas of concern trenches are believed to exist. Because of this, there is a potential for surface water runoff to expose buried waste, if present, during significant rainfall events.

\subsection{Contaminants of Potential Concern}

Based on process knowledge, COPCs at the DTRSA are believed to consist of plutonium, depleted uranium, volatile organic compounds (VOCs), semivolatile organic compounds (SVOCs), total petroleum hydrocarbons (TPH), and metals. Pesticides, polychlorinated biphenyls (PCBs), and radionuclides other than plutonium and depleted uranium are not expected at the DTRSA.

\subsection{Preliminary Action Levels}

Field screening levels for on-site field screening methods and preliminary action levels for off-site analytical methods will be used to determine the presence of contamination.

\subsubsection{Field Screening Levels}

The following field screening levels will be used for on-site field screening methods:

- Volatile organic compound headspace screening levels are established at 20 parts per million (ppm) or 2.5 times background, whichever is greater.

- Total petroleum hydrocarbon screening levels are greater than 100 ppm. 
- Radiation (alpha and beta/gamma) screening is the mean background activity level plus two times the standard deviation of the mean background activity level (to be determined prior to start of field activities.

Details of the methodology to determine the radiological field screening levels can be found in Table A.3-1 and Attachment 2 of the DQO worksheet (Appendix A).

Concentrations exceeding field screening levels indicate potential contamination at that sample location. This information will be documented, and the investigation will be continued to delineate the extent of the contamination. Additionally, this data may also be used to select discretionary laboratory sample locations.

\subsubsection{Chemical Preliminary Action Levels}

Off-site laboratory analytical results will be compared to the following preliminary action levels to evaluate the need for possible corrective actions:

- NDEP Corrective Action Regulations (NAC, 1996a)

- TPH concentrations above the TPH limit of 100 ppm per the Nevada Administrative Code (NAC) 445A.2272 (NAC, 1996a)

The comparison of laboratory results to preliminary action levels will be discussed in the Corrective Action Decision Document (CADD). Laboratory results above action levels indicate the presence of COPCs at levels that may require corrective action. The evaluation of potential corrective actions and the justification for a preferred action will be included in the CADD based on the results of this field investigation.

\subsubsection{Radiological Preliminary Action Levels}

The preliminary action levels for radioactive contaminants of potential concern will be defined in accordance with the guidance described in the Multi-Agency Radiation Survey and Site Investigation Manual (MARSSIM) (NRC, 1997). The MARSSIM provides detailed guidance for designing, conducting, and documenting radiological surveys. MARSSIM provides guidance on how to evaluate survey results prior to making a decision regarding whether or not the radionuclide concentration at a site exceeds the concentration in a background area. The assumption will be made 
that any difference in the distribution of the radionuclide concentrations between the background area and the areas of concern within the DTRSA is due to the presence of residual radioactivity in addition to background. As stated in Section 8.4.1 of MARSSIM, some DTRSA analytical results may be larger than some background area results, while still not exceeding background concentrations. The result of the hypothesis testing determines whether or not the areas of concern within the DTRSA are deemed to exceed the background area.

The evaluation of potential corrective actions and the justification for a preferred action will be included in the CADD based on the results of this field investigation.

\subsection{DQO Process Discussion}

Details of the DQO process are presented in Appendix A. The DQO results indicated the need for excavation activities prior to sampling to locate the boundaries of the areas of concern. The DQO results indicated the need for biased sampling for the animal burial pit. The biased sampling approach will also be applied to the decontamination facility, only if the boundaries can be identified through preliminary excavation activities; otherwise, a systematic random sampling approach for collecting confirmatory samples will be implemented. Due to the potential subsurface migration of COPCs, an investigation consisting of subsurface sampling was identified. The COPCs, analytical methods, and reporting limits prescribed through the DQO process are provided in Table 3-1.

The precision and accuracy requirements are those stated in EPA Contract Laboratory Program Statements of Work (EPA, 1994a; 1994b; 1994c). The sampling size and design and analytical results will be used to defend or refute the conceptual model. 
Table 3-1

Laboratory Analytical Requirements

\begin{tabular}{|c|c|c|c|c|c|}
\hline Analyte & Medium $^{a}$ & $\begin{array}{l}\text { Analytical } \\
\text { Method }\end{array}$ & $\begin{array}{l}\text { Minimum } \\
\text { Reporting } \\
\text { Limit }^{b}\end{array}$ & $\begin{array}{l}\text { Precision } \\
\text { (RPD) }\end{array}$ & $\begin{array}{c}\text { Accuracy } \\
(\% R)\end{array}$ \\
\hline \multirow{2}{*}{ Total VOCs } & Water & \multirow{2}{*}{$8260 B^{c}$} & \multirow{2}{*}{$\begin{array}{c}\text { Analyte-specific } \\
\text { estimated } \\
\text { quantitation limits }\end{array}$} & $\overline{14}$ & $\overline{660-132}$ \\
\hline & Soil & & & 24 & $59-172$ \\
\hline \multirow{2}{*}{ Total SVOCs } & Water & \multirow{2}{*}{$8270 C^{c}$} & \multirow{2}{*}{$\begin{array}{c}\text { Analyte-specific } \\
\text { estimated } \\
\text { quantitation limits }^{d}\end{array}$} & 50 & $5-230$ \\
\hline & Soil & & & 50 & $11-142$ \\
\hline $\begin{array}{c}\text { Total RCRA Metals } \\
\text { Arsenic } \\
\text { Barium } \\
\text { Cadmium } \\
\text { Chromium } \\
\text { Lead } \\
\text { Mercury } \\
\text { Selenium } \\
\text { Silver }\end{array}$ & Water & $6010 \mathrm{~B} / 7470 \mathrm{~A}^{\mathrm{C}}$ & $\begin{array}{c}10 \mu \mathrm{g} / \mathrm{L} \\
200 \mu \mathrm{g} / \mathrm{L} \\
5 \mu \mathrm{g} / \mathrm{L} \\
10 \mu \mathrm{g} / \mathrm{L} \\
3 \mu \mathrm{g} / \mathrm{L} \\
0.2 \mu \mathrm{g} / \mathrm{L} \\
5 \mu \mathrm{g} / \mathrm{L} \\
10 \mu \mathrm{g} / \mathrm{L}\end{array}$ & 20 & $75-125$ \\
\hline $\begin{array}{c}\text { Total RCRA Metals } \\
\text { Arsenic } \\
\text { Barium } \\
\text { Cadmium } \\
\text { Chromium } \\
\text { Lead } \\
\text { Mercury } \\
\text { Selenium } \\
\text { Silver }\end{array}$ & Soil & $6010 \mathrm{~B} / 7471 \mathrm{~A}^{\mathrm{C}}$ & $\begin{array}{c}1 \mathrm{mg} / \mathrm{kg} \\
20 \mathrm{mg} / \mathrm{kg} \\
0.5 \mathrm{mg} / \mathrm{kg} \\
1 \mathrm{mg} / \mathrm{kg} \\
0.3 \mathrm{mg} / \mathrm{kg} \\
0.1 \mathrm{mg} / \mathrm{kg} \\
0.5 \mathrm{mg} / \mathrm{kg} \\
1 \mathrm{mg} / \mathrm{kg}\end{array}$ & 20 & $75-125$ \\
\hline \multirow{4}{*}{ TPH } & Water (gasoline) & \multirow{4}{*}{ 8015B modified ${ }^{C}$} & $1 \mathrm{mg} / \mathrm{L}$ & 20 & $25-145$ \\
\hline & Water (diesel) & & $1 \mathrm{mg} / \mathrm{L}$ & 20 & $25-145$ \\
\hline & Soil (gasoline) & & $1 \mathrm{mg} / \mathrm{kg}$ & 30 & $30-130$ \\
\hline & Soil (diesel) & & $30 \mathrm{mg} / \mathrm{kg}$ & 30 & $30-130$ \\
\hline \multirow{2}{*}{ Isotopic Plutonium } & Water & NAS-NS-3058 ${ }^{\mathrm{e}}$ & $2 \mathrm{pCi} / \mathrm{L}$ & 20 & $80-120$ \\
\hline & Soil & NAS-NS-3058 ${ }^{\mathrm{e}}$ & $0.5 \mathrm{pCi} / \mathrm{g}$ & 20 & $80-120$ \\
\hline \multirow{2}{*}{$\begin{array}{l}\text { Isotopic Uranium } \\
\left(\mathrm{U}^{238}\right)\end{array}$} & Water & \multirow{2}{*}{ NAS-NS-3050 e, f, g } & $2 \mathrm{pCi} / \mathrm{L}$ & 20 & $80-120$ \\
\hline & Soil & & $1 \mathrm{pCi} / \mathrm{g}$ & 20 & $80-120$ \\
\hline
\end{tabular}

${ }^{\mathrm{a}} \mathrm{QC}$ (water) samples area included in table

${ }^{b}$ Industrial Sites Quality Assurance Project Plan (DOE/NV, 1996d)

'EPA Test Methods for Evaluating Solid Waste, 3rd Edition, Parts 1-4, SW-846 (EPA, 1996)

Estimated Quantitation Limit (EQL) as given in SW-846, U.S. EPA (EPA, 1996)

e National Academy of Science, Nuclear Science Series, September 1963

${ }^{\dagger}$ Separation and Preconcentration of Uranium from Acidic Media by Extraction Chromotography (Horwitz et al. 1992)

${ }^{9}$ Separation and Preconcentration of Actinides from Acidic Media by Extraction Chromotography (Horwitz et al. 1993)

$\mathrm{mg} / \mathrm{kg}=$ Milligram(s) per kilogram

$\mathrm{pCi} / \mathrm{L}=$ Picocurie $(\mathrm{s})$ per liter

$\mathrm{mg} / \mathrm{L}=$ Milligram(s) per liter

$\mathrm{pCi} / \mathrm{g}=$ Picocurie(s) per gram

$\mu \mathrm{g} / \mathrm{L}=$ Microgram(s) per liter

$\mathrm{RCRA}=$ Resource Conservation and Recovery Act 


\subsection{Field Investigation}

This section of the CAIP contains the sampling approach for investigating the DTRSA. All sampling activities will be conducted in compliance with the Industrial Sites QAPP (DOE/NV, 1996d) and other applicable, approved procedures. Quality assurance and quality control requirements for field and laboratory environmental sampling are also contained in the Industrial Sites QAPP (DOE/NV, 1996d) and in Table 3-1.

The field investigation at the DTRSA will consist of two phases. The first phase will involve excavation activities to delineate the boundaries of the decontamination facility (i.e., vehicle decon pad and sump) and the animal burial pit (details provided in Section 4.2). The second phase will involve drilling boreholes and collecting environmental samples at selected sites within the DTRSA based on data collected during the excavation phase (details provided in Section 4.3).

Field activities will be performed in accordance with an approved SSHASP; which concurs with the DOE Integrated Safety Management System. Safety, health, and protection of the environment take precedence over expediency and short cuts. Site personnel will take every reasonable step to reduce the possibility of injury, illness, or accidents, and to protect the environment during all project activities. The following will be taken into consideration when accessing the hazards associated with the field activities:

- Potential hazards to site personnel (plutonium, DU, heavy equipment, VOCs, rapidly changing weather, remote location, ordnance)

- Proper training of personnel to mitigate the anticipated hazards

- Engineering controls, where feasible, to reduce exposures

- Work controls to reduce hazards

- Monitoring for VOCs and radioactivity performed to minimize and control potential personnel exposures

- Exposures to be kept as low as reasonably achievable (ALARA)

- Communications (remote location) 


\subsection{Technical Approach}

The following activities will be conducted during the site investigation:

- Excavate test pits to identify and verify the boundaries of the decon facility and the animal burial pit.

- Drill a minimum of two boreholes per identified area of concern to investigate the presence and extent of subsurface COPCs at the suspected location of the animal burial pit.

- If the boundaries of the decon facility are identified, drill a minimum of one borehole per identified area of concern (i.e., sump, decon pad) to investigate the presence and extent of subsurface COPCs.

- If the boundaries of the decon facility are not identified, collect confirmation samples based on field screening levels and visual observations.

- Drill two boreholes for the collection of background samples and to record subsurface geological conditions; and excavate one background test pit to record subsurface geological conditions.

- Drill step-out borings as needed to evaluate the lateral and vertical extent of COPCs.

Field screening and environmental sampling will be conducted during the investigation, and the results will be used during the corrective action decision process. In the following sections, the elements of the field investigation are described in greater detail.

\subsection{Excavation Activities}

The first phase of the field investigation will consist of excavating trenches/test pits along a defined line in an attempt to identify and delineate the boundaries of the decon facility and the animal burial pit. Locating the trench boundaries is imperative to placing soil borings in areas most likely to encounter COPCs. A description of phase one activities and a decision diagram were discussed in the DQO process and details are available in Section A.7.0 of Appendix A. Through investigative methods previously discussed in Section 2.5, several proposed trenching lines have been identified for potential excavation in both the northern and southern halves of the DTRSA. Figure 4-1 shows the approximate locations of areas to be excavated. These areas may be altered at the discretion of the Site Supervisor during the field investigation. 


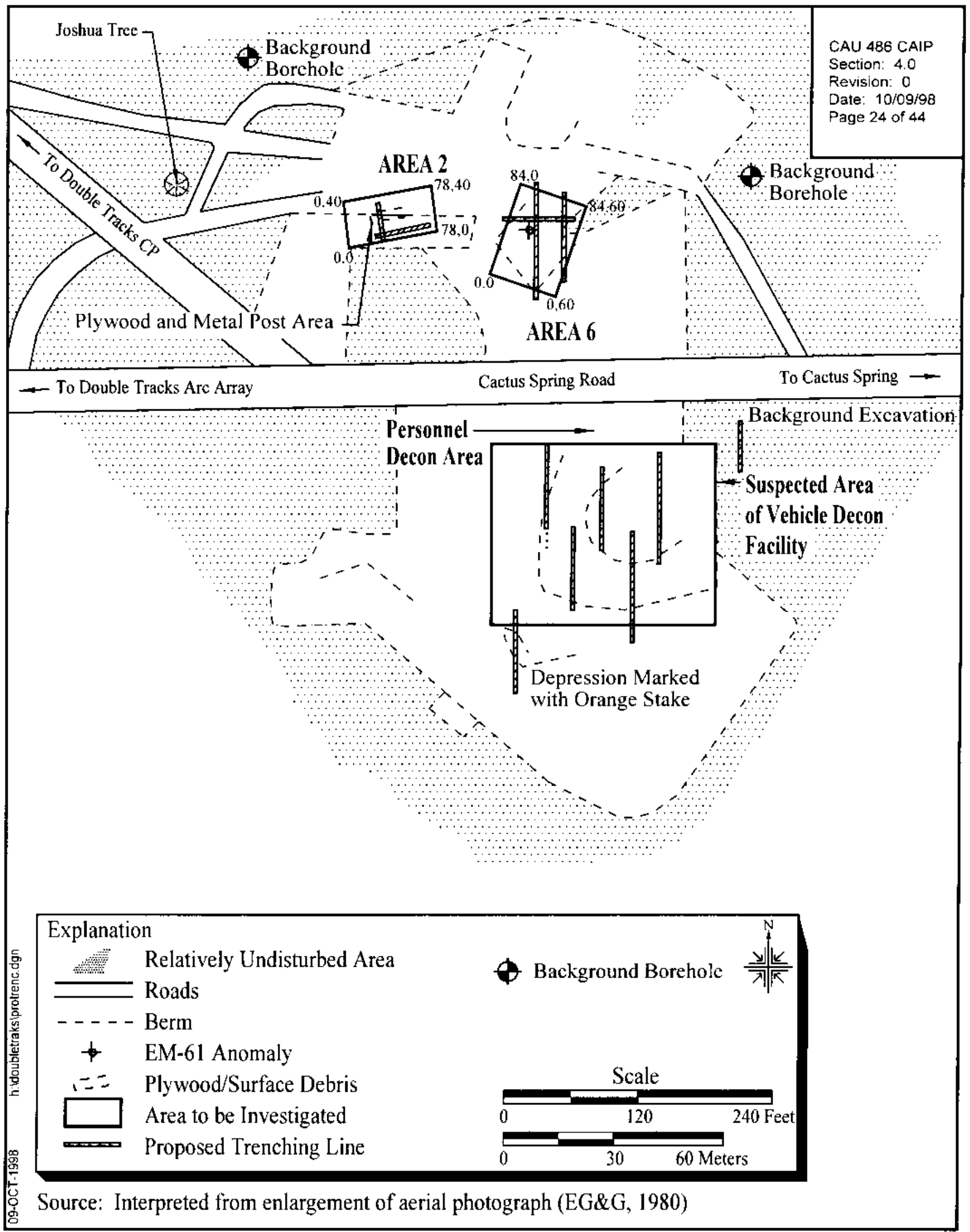

Figure 4-1

Proposed Trenching Lines 
In general, excavation activities will consist of using a backhoe to excavate trenches or test pits to an approximate depth of $1.5 \mathrm{~m}(5 \mathrm{ft})$ and a maximum length of $6 \mathrm{~m}(20 \mathrm{ft})$. The excavations will progress down the proposed trenching lines as shown in Figure 4-1 and Figure 4-2, at 1.5 to $3 \mathrm{~m}$ ( 5 to $10 \mathrm{ft}$ ) intervals until a boundary has been identified or the line is completed. Identifying the site boundaries will be conducted by visual assessment of soil characteristic changes (i.e., gravel layer, fill material/native soil interface) including the observation of trash or debris within the test pit, and through field screening for VOCs and radionuclides. If a north-south trench boundary is identified, then linear step-outs will be excavated to identify and delineate the east-west boundary of the trench. Based on historical information, excavating to a depth of $1.5 \mathrm{~m}(5 \mathrm{ft})$ should be sufficient for encountering evidence of the trenches.

The possibility exists that the Area 2 and 6 anomalies (Figure 2-3 and Figure 4-2) may be buried ordnance associated with historic and current activities at the bombing range. Health and safety precautions pertaining to buried ordnance will be in place during the field investigation activities at both the Area 2 and Area 6 anomalies. A minimum of one Unexploded Ordnance (UXO) specialist will be present during trenching activities at these anomalies. The UXO specialist will survey the excavation area prior to and during excavation activities to verify the proximity to buried metallic objects and identify whether the buried object may be ordnance based on the results of their field survey. The UXO specialist will use a metal/ordnance detector (i.e., a Schonstedt magnetometer or a Foerster Ferex Ordnance Locator) for conducting their surveys.

In the case that a buried ordnance is located, excavation activities at that location will stop and the situation evaluated. If it is safe to continue activities at a different area (either an anomaly or the area south of the road) then activities will move to the other location and a decision regarding the ordnance will be made based on the findings at the remaining anomaly/areas (i.e., the trench is identified and the ordnance requires removal/demilitarization prior to site closure). Additional health and safety precautions pertaining to buried ordnance will be discussed in more detail in the SSHASP for this project.

In the event the decon facility trench boundaries cannot be delineated by visual assessment and field screening results are below field screening levels, then two consecutive clean soil samples will be collected from random excavated test pits for off-site laboratory analysis to confirm COPCs are 


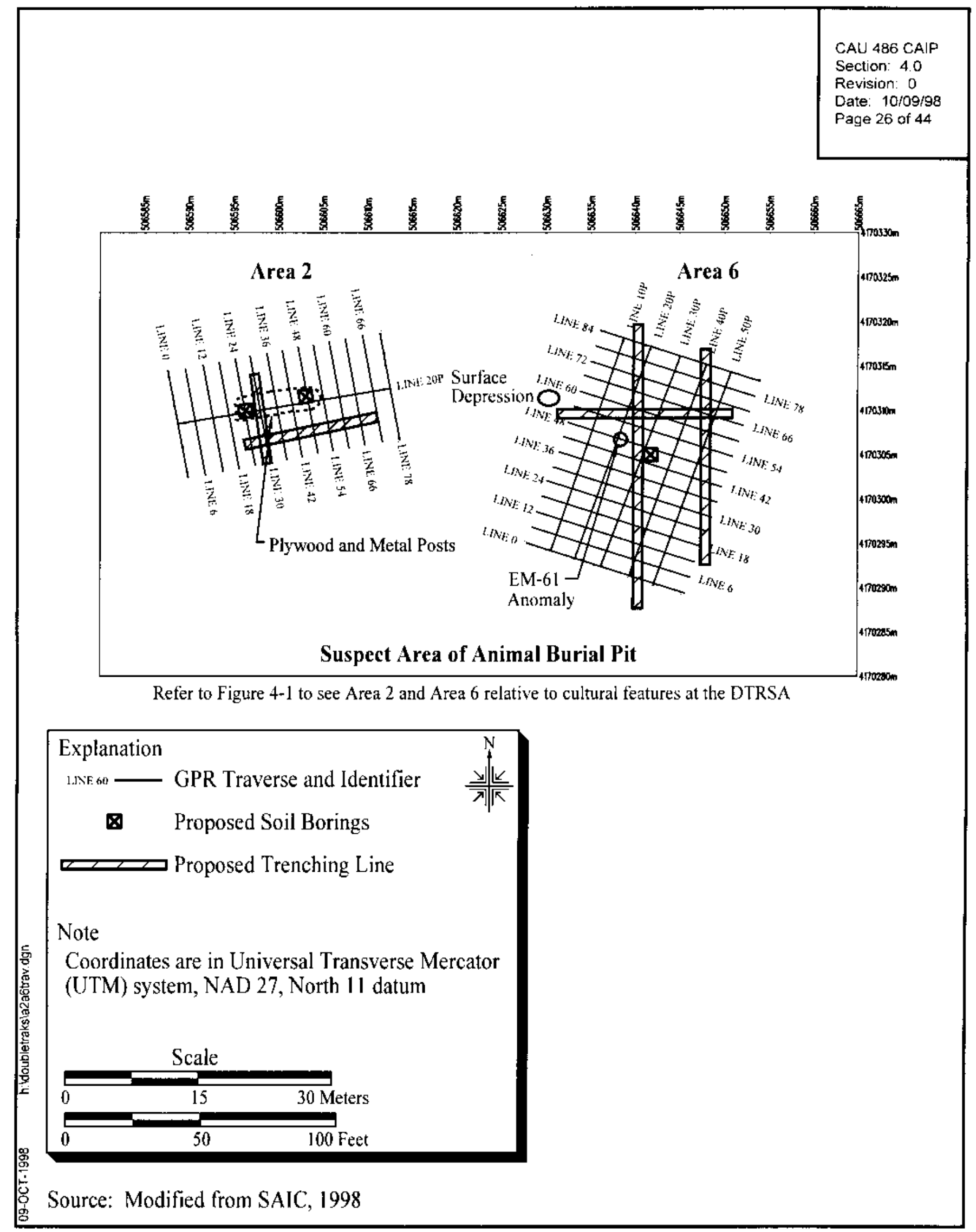

Figure 4-2

Area 2 and Area 6 Geophysical Traverse Location Maps with Potential Soil Boring Locations 
below preliminary action levels. These samples will be analyzed for the constituents listed in Table 3-1. This will eliminate drilling unnecessary boreholes for confirmatory samples. In the case elevated readings above preliminary action levels are obtained from confirmatory samples, subsurface investigation will be performed as described in Section 4.3 at these locations. Random sample locations will be determined from grid cells imposed over the surface of a defined area. The grid method would allow sampling that could statistically demonstrate that the contamination does not exist or is below preliminary action levels.

The DQO process (Appendix A) uses Equation 8 in Chapter 9 of SW-846 (see Section A.6.0) to define the sampling grid and number of samples necessary to verify that COPCs are below preliminary action levels. Since this equation applies the student $t$ value which assumes normal distribution of contaminants, it may not always be applicable to this investigation. The distribution of COPCs, especially plutonium, is rarely normally distributed. Therefore, as an alternative to Equation 8 in Chapter 9 of SW-846, the number of samples to be collected may be calculated using the guidance in Section 9 of NUREG 1505 (Gogolak et al., 1998).

A background trench/test pit will be excavated on the alluvial fan surface near the DTRSA to assess and record undisturbed subsurface geological conditions. This background data will be useful in comparing subsurface geological conditions and identifying fill material/native soil interfaces for phase one activities at the DTRSA.

Excavated soil will be used to backfill the location of removal. During excavation, soil will be stockpiled on plastic sheets as near the excavation as safely possible. The soil will be excavated and stockpiled in layers. The layers will be returned to the excavation hole in the opposite order as they were removed in an expedient manner. This process will help control the potential spread of any COPCs while considerably reducing the amount of potentially-contaminated media requiring management at the site, and reducing associated costs.

\subsection{Subsurface Sampling}

The second phase of the field investigation will consist of drilling boreholes and collecting environmental samples. The number and placement of soil borings required to define the subsurface conditions will be determined at the completion of the first phase (excavation activities). Borings will 
be placed in biased locations within the identified trench boundaries (i.e., along the linear axis, near metallic anomalies, or physical evidence at the surface) in areas most likely to encounter COPCs. Potential boring locations for the animal burial pit, based only on geophysical and physical evidence gathered to date, are shown on Figure 4-2. Potential boring locations for the decon facility will be determined based on delineation of the facility boundaries in phase one activities. If facility boundaries are not identified then confirmation samples will be collected from random test pit locations as discussed in Section 4.2.

Borings will be advanced in 1.5-m (5-ft) intervals starting from the ground surface to a minimum depth of $6 \mathrm{~m}(20 \mathrm{ft}) \mathrm{bgs}$. These borings should adequately bound potential vertical contamination at the site. If two consecutive, nondetect field screening readings are not obtained above a depth of $6 \mathrm{~m}$ (20 ft) bgs, drilling and field screening will continue at 1.5-m (5-ft) intervals until two consecutive, nondetect field screening readings are obtained. Section 4.3.1 provides additional details on field screening methods.

Step-out borings may be drilled to further delineate the lateral and vertical extent of COPCs. The location and depth of proposed step-out borings will be based on the results of the initial borings and at the discretion of the Site Supervisor, and will be drilled in the same manner as the initial borings.

Sonic drilling or another appropriate drilling method will be used to advance the boreholes. The drilling method will meet the following requirements:

- Provide continuous core for environmental sample collection and geologic description; and to allow the fill material and native soil interface depth to be determined.

- Provide high-quality, relatively undisturbed samples.

- Allow reasonable drill rates and penetration of substantial gravel fill and most solid waste.

- $\quad$ Limit the volume of investigation-derived waste (IDW).

\subsubsection{Field Screening}

The field-screening methods include radiological screening using instruments such as a field instrument for the detection of low energy radiation (FIDLER) to detect low energy gamma, and an Electra for alpha and beta emitters. Headspace testing for VOCs will use a photoionization detector. 
Field screening for radioactivity and VOCs will be conducted on samples of soil excavated from the test pits and will provide an additional investigative tool in identifying the decon facility and animal burial pit by identifying areas where COPC concentrations exceed field screening levels. If field screening results exceed the field screening levels listed in Section 3.3, excavation activities will stop for that test pit and the results and location recorded. Field screening will be performed at the midway point and bottom of the test pit, or at the discretion of the Site Supervisor.

Field screening for radioactivity and VOCs will also be conducted for all soil borings and will provide information to establish the required maximum drilling depth for each borehole and the need for step-out borings. If field-screening results exceed the field screening levels listed in Section 3.3, drilling will continue until two consecutive results below these levels are obtained. Field screening will be performed at approximately $0.76-\mathrm{m}(2.5-\mathrm{ft})$ intervals to around $6 \mathrm{~m}(20 \mathrm{ft}) \mathrm{bgs}$ for all borings. If drilling continues beyond this depth, field screening will continue in $1.5-\mathrm{m}(5-\mathrm{ft})$ intervals to total depth.

Field-screening data will serve three purposes. First, the data will provide semiquantitative measurement of the subsurface conditions. Second, the data will provide a mechanism for guiding both depth and lateral extent of the investigation. Third, the data will be used to aid the selection of samples to be submitted for laboratory analysis.

\subsubsection{Sampling Criteria}

Environmental samples will be collected in approximately $1.5-\mathrm{m}(5-\mathrm{ft})$ intervals beginning at the surface and continuing for the entire length of each boring. The bottom two samples with nondetect field screening results will be submitted for laboratory analysis to bound the vertical extent of contamination and verify field-screening results for each individual boring. Additionally, a sample from the interval with the highest field-screening measurement will be submitted for laboratory analysis. Samples submitted to the laboratory will be analyzed in accordance with Table 3-1.

To better delineate potential vertical migration beneath the trench, an increased sampling frequency will be used for the first five-foot interval from the interface between the fill material and the native soil (assuming it can be identified), as core recovery allows, up to $0.3-\mathrm{m}$ (1-ft) intervals and up to five samples. These samples will be field screened, sent to the laboratory, and analyzed for radionuclides 
only. This interface should be apparent in the boring through the vehicle decontamination pad, but may be difficult to recognize in borings penetrating features where no gravel was present (i.e., animal burial pit) or was removed (i.e., hotline). If this interface is difficult to recognize, the increased sampling interval will be used from the anticipated interface for each individual sampling site to obtain vertical definition of COPC extent to support evaluation in the CADD. Additional samples may be collected at the discretion of the Site Supervisor.

All equipment which contacts soil to be sampled will be decontaminated in accordance with written and approved procedures consistent with the Environmental Restoration Division Procedure ERD-05-701, "Sampling Equipment Decontamination,” Rev. 1 (DOE/NV, 1998c), or as appropriate for special equipment being decontaminated (i.e., decontaminating core barrels). Core barrels will be decontaminated prior to each sampling event and between boreholes to minimize the potential for cross-contamination of samples from different sample locations or depths.

Environmental samples collected for laboratory analysis will be samples of fresh (unused) media. Samples will be collected with highest priority given to those that will be analyzed for VOCs. When volatilization of COPCs is not a concern, the soil will be homogenized and the samples will be collected with priority given to those with the shortest hold times prior to analysis.

The analytes, analytical methods, and associated quality control ranges for precision and accuracy measurements of samples submitted to the laboratory are specified in Table 3-1. Records will be maintained for a visual classification of the soil, field-screening measurements, and all other relevant data. Pertinent and required sampling information (e.g., date, time, sample interval) will be documented in accordance with the Industrial Sites QAPP (DOE/NV, 1996d). Approved chain of custody procedures will be followed to assure data defensibility (DOE/NV, 1998b).

\subsection{Quality Control Samples}

Quality control samples will be collected as required by the Industrial Sites QAPP (DOE/NV, 1996d). These samples will include trip blanks, equipment blanks, field blanks, field duplicates, and matrix spike/matrix spike duplicate (MS/MSD) samples. Except for trip blanks, all QC samples will be analyzed for applicable parameters in Table 3-1. Trip blanks will only be analyzed for VOCs. One set of QC samples will be collected for every twenty (or fraction of twenty) environmental 
characterization samples submitted to the laboratory. Additional QC samples may be submitted at the discretion of the Site Supervisor.

\subsection{Background Samples}

Background samples will be collected from two background boreholes drilled north and northeast of the DTRSA (Figure 4-1) in areas not known to have been disturbed by Double Tracks operations. The locations are upslope and upgradient of the DTRSA. The Double Tracks testing was conducted to the west of the DTRSA. These boreholes will be drilled and samples will be collected at $1.5 \mathrm{~m}$ ( $5 \mathrm{ft}$ ) intervals in the same manner as the boreholes described in Section 4.3 of this CAIP. Background information will be used to evaluate data for use in the CADD and in the dose and risk assessment to support the corrective action at this site.

\subsection{Geotechnical Samples}

In addition to environmental samples, geotechnical samples will be collected from both the fill material above the original DTRSA operational features (e.g., gravel vehicle decontamination pad, animal burial pit) and in the native soil directly beneath the fill material/native soil interface. A minimum of one pair of geotechnical samples will be collected per area of concern. Analysis of geotechnical parameters listed in Table 4-1 will be performed by an off-site, fixed-base laboratory. The methods shown are minimum standards and other equivalent or superior testing methods may be used. 
Table 4-1

Geotechnical Analyses

\begin{tabular}{|c|c|}
\hline Geotechnical Parameter & Methods \\
\hline Initial moisture content & ASTM $^{\mathrm{a}}$ D 2216-92 \\
\hline Dry bulk density & ASTM $^{\mathrm{a}}$ D 2937-94 \\
\hline Calculated porosity & $\begin{array}{c}\text { EM }^{\mathrm{b}}-1110-2-1906 \text { or } \\
\text { MOSA }^{\mathrm{c}} \text { Chp. } 18\end{array}$ \\
\hline Saturated hydraulic conductivity & $\begin{array}{c}\text { ASTM }^{\mathrm{a}} \text { D 2434-68(74) } \\
\text { MOSA }^{\mathrm{c}} \text { Chp. } 28\end{array}$ \\
\hline Unsaturated hydraulic conductivity & van Genuchten $^{d}$ \\
\hline Particle-size distribution & ASTM $^{\mathrm{a}}$ D 422-63(90) \\
\hline Water-release (moisture retention) curve & $\begin{array}{c}\text { MOSA }^{\text {C }} \text { Chp. } 26 \\
\text { ASTM }^{\mathrm{a}} \text { D 2325-68(94) } \\
\text { MOSA }^{\mathrm{C}} \text { Chp. } 24 \\
\text { Karanthanasis and Hajek }\end{array}$ \\
\hline
\end{tabular}

\footnotetext{
${ }^{a}$ ASTM, 1996

bUSACE, 1970

'MOSA, 1986 (Soil Science Society of America)

dvan Genuchten, 1980

e Karanthanasis and Hajek, 1982
} 


\subsection{Waste Management}

Management of IDW will be based on regulatory requirements, field observations, process knowledge, and the results of laboratory analysis of DTRSA investigation samples. Decontamination activities will be performed according to approved contractor procedures specified in the contractor field sampling instructions and as appropriate for the COPCs likely to be identified at the DTRSA.

Waste other than soil is potentially contaminated waste only by virtue of contact with potentially contaminated media. Therefore, sampling and analysis of IDW, separate from analyses of site characterization samples, will not be required. The data generated as a result of site characterization and process knowledge will be used to assign the appropriate waste type (i.e., sanitary, hazardous, low-level radioactive waste [LLW], or mixed) to the IDW with the exception noted in Section 5.3.

Sanitary, hazardous, radioactive, and/or mixed waste, if generated, will be managed and disposed of in accordance with U.S. Department of Energy (DOE) Orders, U.S. Department of Transportation (DOT) regulations, Resource Conservation and Recovery Act (RCRA) regulations, "Nevada Revised Statutes" (NAC, 1996b), and agreements and permits between the DOE and NDEP.

In the following sections, operational requirements are provided for managing sanitary, hazardous, low-level radioactive, and mixed wastes. However, when the waste is initially generated, the waste will be managed according to mixed waste requirements until laboratory analyses are received and a final waste determination is made.

\subsection{Waste Minimization}

Corrective action investigation activities have been planned to minimize IDW generation.

Decontamination activities are planned to minimize the use of rinsate; decontamination materials will consist of detergent, water, and wipes. Waste, such as disposable sampling equipment, decon rinsate, and PPE will be segregated to the greatest extent possible to minimize the generation of hazardous, radioactive, and/or mixed waste. 


\subsection{Potential Waste Streams}

Historical records and process knowledge indicate that MEK was used to clean respirators and the associated wipes may have been disposed of in the trenches at the DTRSA. If MEK contamination is confirmed the associated waste will be considered to be "listed waste" if other waste regulated by RCRA are identified they will be considered to be "characteristic." Wastes generated during the investigation activities will include the following:

- Potentially contaminated disposable sampling equipment (such as plastic, paper, sample containers, aluminum foil, spoons, scoops, and bowls) and PPE

- Decontamination rinsate

- Potentially contaminated soil

The waste will be managed in three waste streams; additional segregation will occur within each waste stream based on sample location. Waste will be traceable to its source and to individual samples.

\subsection{Investigation-Derived Waste Management}

To allow for the segregation of radioactive and nonradioactive waste and materials, radiological swipe surveys may be conducted on reusable sampling equipment and the PPE and disposable sampling equipment waste streams exiting from within the controlled area. Removable contamination limits, as defined in Table 2-2 of the DOE/NV NV/YMP Radiological Control Manual (DOE/NV, 1996c), shall be used to determine if such materials may be declared nonradioactive. Due to safety considerations including winter road conditions and ongoing activities at the Nellis Air Force Range, waste will be transferred to a radioactive materials area at the TTR and temporarily stored in accordance with 40 CFR 262.34 (CFR, 1997a). It is anticipated that this transfer will be performed when field activities are complete. Once a radiological or nonradiological disposition has been made for a particular waste stream, a sanitary or hazardous waste disposition will be made. The final disposition of such wastes will be determined by evaluating the analytical results of acquired soil samples. Management requirements for sanitary, low-level, hazardous, or mixed wastes are discussed further in the following sections. 


\subsubsection{Sanitary Wastes}

Sanitary waste generated outside the controlled area will be contained in plastic bags and will be transported to a solid waste management unit. Sanitary waste generated within the controlled area will be swiped to determine if the removable contamination is under the limits defined in Table 2-2 of the NV/YMP Radiological Control Manual (DOE/NV, 1996c). Analytical results from the swipe surveys will be used to determine if removable materials will be declared nonradioactive, and analytical results from soil sampling will be used to determine if the materials will be declared sanitary.

\subsubsection{Low-Level Radioactive Waste}

Low-level radioactive waste, if generated, will be managed in accordance with the contractor-specific waste certification program plan and the Nevada Test Site Waste Acceptance Criteria (NTSWAC) (DOE/NV, 1997). Waste drums containing soil, PPE and disposable sampling equipment, and rinsate (when full) shall be staged at a designated Radioactive Material Area pending certification and disposal under NTSWAC requirements (DOE/NV, 1997). Waste drums shall be labeled "Radioactive Material Pending Analysis." All drums shall be locked or fitted with tamper-indicating devices (TIDs). Traceability shall be maintained by assigning unique waste tracking numbers to each container and by maintaining records that trace the IDW back to the original sampling locations.

The PPE and disposable sampling equipment shall be placed in clear plastic bags marked with the date and an associated borehole number. The bags will be tagged with a contractor-specific waste tracking tag and logged in the contractor-specific waste management logbook.

Soil generated during borehole advancement (cuttings) shall be collected in 55-gallon drums that meet DOT specifications (49 CFR 172) (CFR, 1997b) and 6-mil liners will be placed in the drums. Cuttings shall be segregated by borehole. Drums used to contain soil shall be inspected prior to use. A drum shall not be used if it is damaged, cannot be locked, or cannot accommodate a TID placed on it. Absorbent Stergo ${ }^{\mathrm{TM}}$ pads shall be added to drums of radiologically contaminated soil waste drums. Contractor-specific waste tracking tags shall be used and may be attached to the inside liner, the exterior of the drums, or marked with the drums's unique identification number, and stored with 
the contractor-specific logbook. The borehole number must be placed on each tracking tag. Drum inspection and absorbent addition shall be documented on the appropriate form.

Rinsate shall be collected in 55-gallon drums that meet DOT specifications (49 CFR 172) (CFR, 1997b) pending further treatment. Rinsate determined to be potentially LLW, may be analyzed separately to determine final disposition.

\subsubsection{Hazardous Waste}

Suspected hazardous waste will be managed in accordance with RCRA and State of Nevada hazardous waste management regulations, interpreted as follows. Suspected hazardous waste will be placed in 55-gallon drums that meet DOT specifications (49 CFR 172) (CFR, 1997b) which will be closed and secured when not in use. The IDW shall be containerized in a manner to comply with Subpart CC of 40 CFR 265 (CFR, 1996b) and the drums shall be compatible with the waste in accordance with the requirements of 40 CFR 265.172 (CFR, 1996b). No incompatible wastes are expected to be generated; however, if incompatible waste is encountered in the field, it will be managed in accordance with 40 CFR 265.177 (CFR, 1996b) (i.e., shall not be placed in the same container) and shall be separated so that in the event of a spill, leak, or release, incompatible wastes shall not contact one another. Drums shall be handled and inspected in accordance with the requirements of 40 CFR 265.173 and 174, respectively (CFR, 1996b).

Hazardous waste shall be characterized in accordance with the requirements of 40 CFR 261 (CFR, 1996a). Characterization will be based on laboratory results and process knowledge. Drums containing IDW pending characterization will be marked with the words "Hazardous Waste Pending Analysis" until its regulatory status can be determined through interpretation and evaluation of laboratory results. Traceability shall be maintained by assigning a unique waste tracking number to each container and by maintaining records that trace the IDW back to the samples. After receipt of analytical results, hazardous wastes, if identified will be labeled and marked in accordance with the requirements of 40 CFR 262.32 (CFR, 1997a) and State of Nevada requirements.

Alpha and gamma spectroscopy are included in the required site characterization analyses to determine if the waste will meet the Nevada Test Site Performance Objectives for Certification of 
Nonradioactive Hazardous Waste (BN, 1995). These analysis are included in the event the waste generated during site characterization is determined to be a hazardous waste.

Hazardous waste management methods to include the establishment of Satellite Accumulation Areas or a 90-day Hazardous Waste Accumulation Area will be employed to temporarily accumulate IDW pending characterization. These methods will be appropriate for the amount of waste being accumulated and in compliance with applicable State of Nevada and federal requirements.

Suspected hazardous waste will be accumulated at or near the site of generation in accordance with 40 CFR 262.34 (CFR, 1997a). Prior to or on the 90th day of accumulation as specified in 40 CFR 262.34 (a) (CFR, 1997a), hazardous waste will be shipped by a licensed/permitted hazardous waste transporter to a permitted treatment storage and disposal facility. If hazardous waste must remain on-site for longer than 90 days due to unforeseen, temporary, and uncontrollable circumstances, a letter requesting an extension for up to 30 days will be sent to the NDEP in accordance with 40 CFR Part 262.11(b) (CFR, 1997a). A copy of the uniform hazardous waste manifest shall be provided to the State of Nevada.

\subsubsection{Mixed Wastes}

Mixed waste, if generated, shall be managed in accordance with RCRA (40 CFR 262) (CFR, 1997a) and State of Nevada NAC 444 (NAC, 1990). These regulations, as well as DOE requirements for radioactive waste, are interpreted as follows. Where there is a conflict in regulations or requirements, the most stringent shall apply. For example, the 90-day accumulation time limit and weekly inspections per RCRA regulations will be applied to mixed waste even though it is not required for radioactive waste. Conversely, while RCRA does not require documented traceability, the waste acceptance program for LLW does; therefore, traceability shall be documented as described in Section 5.3.2.

In general, mixed waste shall be managed in the same manner as hazardous waste, with added mandatory radioactive waste management program requirements. Suspected mixed waste will be managed in accordance with applicable regulations and requirements and will be marked with the words "Hazardous Waste Pending Analysis" pending characterization and confirmation of its regulatory status. However, once the waste determination is made, or the RCRA 90-day time 
requirement draws to an end, mixed waste shall be transported via a permitted hazardous waste hauler to the Nevada Test Site (NTS) transuranic (TRU) waste storage pad for storage pending treatment or disposal. Mixed waste with hazardous waste constituents below land disposal restrictions may be accepted for disposal at the Area 5 Radioactive Waste Management Site.

Mixed waste not meeting land disposal restrictions will require development of a treatment plan under the requirements of the Mutual Consent Order between DOE and the State of Nevada (NDEP, 1995). 


\subsection{Duration and Records Availability}

\subsection{Duration}

After the submittal of the CAIP to NDEP (FFACO milestone date of February 26, 1999), the following is a tentative schedule of activities (in calendar days):

- Day 0: Preparation for field work will begin.

- Day 60: The field work, including field screening and sampling, will begin. Samples will be shipped to meet lab holding times.

- Day 110: The field work will be completed.

- Day 185: The quality-assured laboratory analytical sample data will be available for review.

- $\quad$ The FFACO date for the CADD is September 30, 1999.

\subsection{Records Availability}

Historic information and documents referenced in this plan are retained in the DOE/NV project files in Las Vegas, Nevada, and can be obtained through written request to the DOE/NV Project Manager. The NDEP maintains the official Administrative Record for all activities conducted under the auspices of the FFACO. 


\subsection{References}

AEC, see U.S. Atomic Energy Commission.

ASTM, see American Society for Testing and Materials.

Adams, Steven. 1998a. E-mail to D. Arnold regarding responses from the Health Physics department to questions about the Double Tracks RADSAFE Area brought up at the DQO meeting, 18 June. Las Vegas, NV: IT Corporation.

Adams, Steven. 1998b. Memo to C. Rodriguez regarding "Review of Preassessment Survey Data for Selected Sites," 8 April. Las Vegas, NV: IT Corporation.

Adams, Steven. 1998c. Memo to B. McCall regarding "Methodology for Determining Preliminary Action Levels for CAU 407, The Roller Coaster RADSAFE Area," 16 June. Las Vegas, NV: IT Corporation.

American Society for Testing and Materials. 1996. Annual Book of American Society for Testing and Materials (ASTM) Standards, Section 4, "Construction," Volume 04.08, "Soil and Rock (1)," and Volume 04.09, "Soil and Rock (11)." Philadelphia, PA.

BN, see Bechtel Nevada.

Bechtel Nevada. 1995. Nevada Test Site Performance Objective for Certification of Nonradioactive Hazardous Waste, G-E11/96.01, Rev. 0. Las Vegas, NV.

Burnett, W.D., H.L. Rarrick, and G.E. Tucker, Jr. 1964. Health Physics Aspects of Operation Roller Coaster, Report \# SC-4973 (RR). Albuquerque, NM: Sandia National Laboratories.

CFR, see Code of Federal Regulations.

Code of Federal Regulations. 1996a. 40 CFR Part 261, "Identification and List of Hazardous Waste." Washington, DC: U.S. Government Printing Office.

Code of Federal Regulations. 1996b. 40 CFR Part 265, "Interim Status Standards for Owners and Operators of Hazardous Waste Treatment, Storage, and Disposal Facilities." Washington, DC: U.S. Government Printing Office.

Code of Federal Regulations. 1997a. 40 CFR Part 262, "Standards Applicable to Generators of Hazardous Waste.” Washington, DC: U.S. Government Printing Office. 
Code of Federal Regulations. 1997b. 49 CFR Part 172, "Hazardous Materials Table, Special Provisions, Hazardous Materials Communications, Emergency Response Information, and Training Requirements." Washington, DC: U.S. Government Printing Office.

DOE, see U.S. Department of Energy.

DOE/NV, see U.S. Department of Energy, Nevada Operations Office.

EG\&G/Energy Measurements. 1980. Aerial photograph, perf \#3309, frame \#092, 08-09-1980.

EPA, see U.S. Environmental Protection Agency.

FFACO, see Federal Facility Agreement and Consent Order.

Federal Facility Agreement and Consent Order. 1996. Agreed to by the State of Nevada, the U.S. Department of Energy, and the U.S. Department of Defense.

Gogolak, C.V., G.E. Powers, and A.M. Huffert. 1998. A Nonparametric Statistical Methodology for the Design and Analysis of Final Status Decommissioning Surveys, NUREG 1505.

Washington, DC: U.S. Nuclear Regulatory Commission.

Hoover, Richard. SAIC. 1998. Memo to M. Foley (SAIC) regarding "Preliminary Geophysical Results Double Tracks RADSAFE Area Corrective Action Unit 486, Corrective Action Site 71-23-001-71DT," 22 March. Las Vegas, NV.

Horwitz, E.P., M.L. Dietz, R. Chiarizia, H. Diamond, A.M. Essling, and D. Graczyk. 1992. "Separation and Preconcentration of Uranium from Acidic Media by Extraction Chromotography." In Analytica Chimica Acta, 266: 25-37.

Horwitz, E.P., R. Chiarizia, M.L. Dietz, H. Diamond, and D.M. Nelson. 1993. "Separation and Preconcentration of Actinides from Acidic Media by Extraction Chromotography." In Analytica Chimica Acta, 281: 361-372.

IT Corporation. 1995. Field Instructions for Geophysical Investigation of Double Tracks and Cactus Springs Sites, DOE/NV/10972-145. Las Vegas, NV.

Karanthanasis, A.D., and B.F. Hajek. 1982. "Quantitative Evaluation of Water Adsorption on Soil Clays.” In Soil Science Society of America Journal, 46: 1321-1325. Madison, WI.

MOSA, see Soil Science Society of America.

NAC, see Nevada Administrative Code.

National Academy of Science. 1963. Nuclear Science Series. 
NDEP, see Nevada Division of Environmental Protection.

Nevada Administrative Code. 1990. NAC444.940 - NAC444.9555, "Solid Waste Disposal." Carson City, NV: Nevada Division of Environmental Protection.

Nevada Administrative Code. 1996a. NAC445A.345 - NAC445A.22755, "Water Controls." Carson City, NV: Nevada Division of Environmental Protection.

Nevada Administrative Code. 1996b. NRS459.9973, 459.9975, and 459.9977, "Hazardous Materials." Carson City, NV: Nevada Division of Environmental Protection.

Nevada Division of Environmental Protection. 1995. "Mutual Consent Agreement Between the State of Nevada and the Department of Energy for the Storage of Low-Level Land Disposal Restricted Mixed Waste." Transmittal from P. Liebendorfer (NDEP) to D. Elle (DOE/NV), 7 June. Carson City, NV.

NRC, see U.S. Nuclear Regulatory Commission.

Penwell, C. 1995. Interview with B. Schier (DBS) regarding the burial pit and decon area at the DTRSA, 11 April. Las Vegas, NV.

Perry, J.K., W.N. Baillie, J.K. Trimble, and R.P. Bloodworth. 1966. Operation Roller Coaster, Project Officers Report-Project 2.6d, Special Particulate Analysis (Soil), POR-2509 (WT-2509). Golden, CO: Colorado School of Mines, Colorado.

REECo, see Reynolds Electrical and Engineering Co., Inc.

Reynolds Electrical and Engineering Co., Inc. 1964. Project Manager's Report, Project Roller Coaster, NVO-10. Prepared for U.S. Atomic Energy Commission, Nevada Operations Office. Las Vegas, NV.

SAIC, see Science Applications International Corporation.

Science Applications International Corporation, R.E. Wright Environmental, Inc. 1998. First Quarter 1998 Surface Geophysical Survey Report Double Tracks Rad Safe Area Corrective Action Unit 486 Corrective Action Site 71-23-001-71DT at the Tonopah Test Range, Tonopah, Nevada, R.E. Wright Project 01-1408-08-3610-000. Middletown, PA.

Sherwood, R.D. 1966. Operation Roller Coaster, Project Officers Report-Project 2.6b, Special Particulate Analysis (U), POR-2507 (WT-2507). Westwood, NJ: Isotopes, Inc.

Shugart, Jim. 1995. Interview with Brad Schier (DBS) regarding a burial pit at the DTRSA, 12 May. Las Vegas, NV.

Soil Science Society of America. 1986. Methods of Soil Analysis, 2nd Edition, Part 1. Madison, WI. 
Sygitowicz, L. Bechtel Nevada. 1998. Interview with M. England (SAIC) regarding Operation Roller Coaster, 10 March. Las Vegas, NV.

USACE, see U.S. Army Corps of Engineers.

U.S. Army Corps of Engineers. 1970. “Laboratory Soils Testing.” In Engineering Manual (EM) 1110-2-1906, Appendix II. Washington, DC.

U.S. Atomic Energy Commission. 1963. Department of Defense Operations Plan, Operation Roller Coaster, 77652. Albuquerque, NM.

U.S. Department of Energy, Nevada Operations Office. 1994b. Project Management Plan, Rev. 0. Las Vegas, NV.

U.S. Department of Energy, Nevada Operations Office. 1996a. Corrective Action Unit Work Plan, Tonopah Test Range, Nevada, Rev. 0. Las Vegas, NV: IT Corporation.

U.S. Department of Energy, Nevada Operations Office. 1996b. Environmental Restoration Project Health and Safety Plan, Rev. 2. Las Vegas, NV.

U.S. Department of Energy, Nevada Operations Office. 1996c. NV/YMP Radiological Control Manual, Rev. 2, DOE/NV/11718-079, UC-702. Las Vegas, NV.

U.S. Department of Energy, Nevada Operations Office. 1996d. Industrial Sites Quality Assurance Project Plan, Nevada Test Site, Nevada, Rev. 1, DOE/NV--372. Las Vegas, NV.

U.S. Department of Energy, Nevada Operations Office. 1997. Nevada Test Site Waste Acceptance Criteria, Rev. 1. Las Vegas, NV.

U.S. Department of Energy, Nevada Operations Office. 1998a. Corrective Action Investigation Plan for the Roller Coaster RADSAFE Area, Corrective Action Unit 407, Tonopah Test Range, Nevada, DOE/NV--503. Las Vegas, NV.

U.S. Department of Energy, Nevada Operations Office. 1998b. ERD-05-201, "Chain of Custody," Rev. 1. Las Vegas, NV.

U.S. Department of Energy, Nevada Operations Office. 1998c. ERD-05-701, "Sampling Equipment Decontamination," Rev. 1. Las Vegas, NV.

U.S. Environmental Protection Agency. 1994a. Contract Laboratory Program: Statement of Work for Inorganics Analysis; Multi-Media, Multi-Concentration, ILMO 3.0, EPA-540/R-94/076. Washington, DC. 
U.S. Environmental Protection Agency. 1994b. Contract Laboratory Program: Statement of Work for Organics Analysis; Multi-Media, Multi-Concentration, OLMO 1.0, Including Revisions OLMO 1.1 Through OLMO 1.8, EPA-540/R-94/078. Washington, DC.

U.S. Environmental Protection Agency. 1994c. Contract Laboratory Program: Statement of Work for Organics Analysis, OLMO 3.1, EPA-540/R-94/073. Washington, DC.

U.S. Environmental Protection Agency. 1994d. Guidance for the Data Quality Objectives Process, EPA QA/G-4. Washington, DC.

U.S. Environmental Protection Agency. 1996. Test Methods for Evaluating Solid Waste, Physical/Chemical Methods, SW-846, 3rd Edition, CDROM. Washington, DC.

U.S. Environmental Protection Agency. 1998. Memo from S.J. Smucker regarding Region 9 Preliminary Remediation Goals (PRGs), 01 August. San Francisco, CA.

U.S. Nuclear Regulatory Commission. 1997. Multi-Agency Radiation Survey and Site Investigation Manual (MARSSIM), NUREG-1575/EPA 402-R-97-016. Prepared by the NRC, EPA, DOE, and DoD. Washington DC: U.S. Government Printing Office

van Genuchten, M. 1980. "A Closed Form Equation for Predicting the Hydraulic Conductivity of Unsaturated Soils.” In Soil Science Society of America Journal, 44: 892-898. El Cerrito, CA.

Wilson, R.H. University of Rochester, N.Y. 1995a. Interview with B. Schier (Daniel B. Stephens and Associates [DBS]) regarding Double Tracks burial pit, 13 April. Las Vegas, NV.

Wilson, R.H. University of Rochester, N.Y. 1995b. Interview with R. Dubiskas (IT Corporation) regarding Double Tracks RADSAFE Area, 2 May. Las Vegas, NV.

Wilson, R.H. and J.L. Terry. 1965. Plutonium uptake by animals exposed to a non-nuclear detonation of a plutonium-bearing weapon simulant, Part I. Field Operations, UR-665. University of Rochester, NY. 
Appendix A

Data Quality Objectives Process 


\section{A.1.0 DQO Kickoff Meeting}

Data Quality Objectives Worksheets for the Double Tracks Radiological Safety Area-CAU 486.

\begin{tabular}{||l|c|c|c||}
\hline \multirow{2}{*}{\multicolumn{1}{|c|}{ Participant }} & \multicolumn{2}{c|}{ Kickoff Meeting } \\
\cline { 2 - 4 } & $\begin{array}{c}\text { Meeting 1 Date } \\
\text { June 17, 1998 }\end{array}$ & $\begin{array}{c}\text { Meeting 2 Date } \\
\text { July 16, 1998 }\end{array}$ & $\begin{array}{c}\text { Meeting 3 Date } \\
\text { July 30, 1998 }\end{array}$ \\
\hline Janet Appenzeller-Wing, DOE & $\mathrm{X}$ & & \\
\hline Karen Beckly, NDEP & $\mathrm{X}$ & & \\
\hline Mike McKinnon, NDEP & $\mathrm{X}$ & $\mathrm{X}$ & $\mathrm{X}$ \\
\hline Kevin Cabble, DOE & $\mathrm{X}$ & $\mathrm{X}$ & $\mathrm{X}$ \\
\hline Cheryl Rodriquez, HSI Geotrans & $\mathrm{X}$ & $\mathrm{X}$ \\
\hline Steve Adams, IT & $\mathrm{X}$ & $\mathrm{X}$ \\
\hline Mark DiStefano, IT & $\mathrm{X}$ & $\mathrm{X}$ \\
\hline Mary Todd, SAIC & $\mathrm{X}$ & & \\
\hline Dawn Arnold, SAIC & $\mathrm{X}$ & & \\
\hline Jeanne Wightman, Mactech & $\mathrm{X}$ & & \\
\hline Cindy Dutro, IT & $\mathrm{X}$ & & \\
\hline Jerry Bonn, BN & $\mathrm{X}$ & & \\
\hline Syl Hersh, IT & $\mathrm{X}$ & & \\
\hline Jason Moore, SAIC & $\mathrm{X}$ & & \\
\hline Marjorie England, SAIC & $\mathrm{X}$ & & \\
\hline Greg Raob, NDEP & $\mathrm{X}$ & & \\
\hline Lori Arent, DOE & $\mathrm{X}$ & & \\
\hline Thomas Fitzmaurice, BN & & & \\
\hline
\end{tabular}




\section{A.2.0 Problem Statement}

\section{A.2.1 State the Problem}

Radioactive wastes and possibly hazardous wastes were disposed at the Double Tracks RADSAFE Area. Existing information is insufficient to identify the locations of historical animal burial sites and the decontamination facility. Lacking this information hinders selecting a preferred corrective action.

\section{A.2.1.1 Problem to be Resolved}

Identify and verify the locations of the animal burial pit, the decontamination facilities for vehicles and personnel, and the decontamination sump. Determine whether COPCs are present in quantities exceeding regulatory levels. If such contamination is detected, determine the extent of the contamination.

\section{A.2.1.2 Site History and Known or Suspected Sources of Contamination}

A facility description including the physical setting, operational history, and suspected/known sources of contamination is described in Section 2.0 of the CAIP. 


\section{A.3.0 Conceptual Model}

\section{A.3.1 Contaminants of Potential Concern}

The site is believed to be contaminated by plutonium and uranium from the decontamination activities associated with the Double Tracks experiment. VOCs, SVOCs, TPH, and metals may be present from the decontamination of vehicles and personnel. Pesticides and PCBs are not expected at this site.

Table A.3-1 lists COPCs, field screening methods if applicable, and laboratory analytical methods. Field screening and laboratory preliminary action levels for the anticipated COPCs or COPC group are also listed in Table A.3-1 and discussed in Figure 3.3 of the CAIP. Analytical methods, reporting limits, and precision and accuracy requirements are discussed in Section 3.4 and Table 3-1 of the CAIP. Field data and laboratory results will be compared to identify COPCs exceeding action levels.

Surface radiological surveys were performed in March 1998 for beta and gamma-emitting radionuclides. The survey covered the disturbed area of the former DTRSA. The results of the survey demonstrate that there is no beta-gamma activity elevated above background on the soil surface of the DTRSA (Adams, 1998b).

\section{A.3.2 Conceptual Site Model}

The conceptual site model describes the most probable scenario for current conditions at the DTRSA. Table A.3-2 defines the assumptions for the DTRSA that are the basis for identifying appropriate sampling strategy and data collection methods. 
Table A.3-1

Contaminants of Potential Concern

\begin{tabular}{|c|c|c|c|c|c|c|}
\hline \begin{tabular}{|c|} 
Potential \\
Contaminants
\end{tabular} & Comments & $\begin{array}{c}\text { Field Screening } \\
\text { Method }\end{array}$ & Field Screening Level & $\begin{array}{l}\text { Analytical } \\
\text { Method }\end{array}$ & $\begin{array}{l}\text { Preliminary } \\
\text { Action Level }\end{array}$ & Source \\
\hline VOCs & $\begin{array}{l}\text { Expected based on } \\
\text { process knowledge } \\
\text { (MEK and alcohol) }\end{array}$ & Headspace & $20 \mathrm{ppm}$ or $2.5 \mathrm{X}$ background (whichever is greater) & $8260^{\mathrm{a}}$ & PRGs ${ }^{b}$ & NAC $445 A^{c}$ \\
\hline SVOCs & $\begin{array}{l}\text { May be expected at } \\
\text { vehicle decon area }\end{array}$ & $\mathrm{N} / \mathrm{A}$ & $\mathrm{N} / \mathrm{A}$ & $8270^{a}$ & PRGs ${ }^{b}$ & NAC $445 A^{C}$ \\
\hline TPH & $\begin{array}{l}\text { May be expected at } \\
\text { vehicle decon area }\end{array}$ & $\begin{array}{l}\text { Hanby or } \\
\text { comparable method }\end{array}$ & $>100 \mathrm{ppm}$ & 8015 Modified $^{\mathrm{a}}$ & $>100$ ppm & NAC $445 A^{c}$ \\
\hline \begin{tabular}{|l} 
Total RCRA \\
Metals \\
\end{tabular} & $\begin{array}{l}\text { May be expected at } \\
\text { vehicle decon area }\end{array}$ & $\mathrm{N} / \mathrm{A}$ & N/A & $6010 / 7470^{a}$ & PRGs ${ }^{b}$ & NAC $445 A^{c}$ \\
\hline Radionuclides & $\begin{array}{l}\text { May be expected } \\
\text { based on process } \\
\text { knowledge }\end{array}$ & $\begin{array}{l}\text { Field screening with } \\
\text { Electra (alpha/beta } \\
\text { scintillator) and a } \\
\text { FIDLER }{ }^{\mathrm{d}} \text { (to identify } \\
{ }^{241} \mathrm{Am} \text { associated } \\
\text { with }{ }^{241} \mathrm{Pu} \text { decay) }\end{array}$ & $\begin{array}{l}\text { Determination of action levels will follow the methodology } \\
\text { used for CAU 407; } 20 \text { background surface soil samples } \\
\text { surveyed for gross alpha, gross beta and gamma activity and } \\
\text { calculate average. Standard deviation will be determined per } \\
\text { the standard deviation equation, not the square root of } \\
\text { average activity. PAL is mean background activity plus two } \\
\text { times standard deviation. See Attachment } 2 \text {. }\end{array}$ & N/A & $\mathrm{N} / \mathrm{A}$ & Adams, 1998c \\
\hline Isotopic Plutonium & $\begin{array}{l}\text { May be expected } \\
\text { based on process } \\
\text { knowledge }\end{array}$ & N/A & N/A & NAS-NS-3058 & $\begin{array}{c}\text { PAL determined by } \\
\text { applying } \\
\text { nonparametric test } \\
\text { to background } \\
\text { concentration. } \\
\end{array}$ & NUREG- $1575^{\dagger}$ \\
\hline $\begin{array}{l}\text { Isotopic Uranium } \\
\text { (U238) }\end{array}$ & $\begin{array}{l}\text { May be expected } \\
\text { based on process } \\
\text { knowledge }\end{array}$ & N/A & N/A & NAS-NS-3050 & $\begin{array}{l}\text { PAL determined by } \\
\text { applying } \\
\text { nonparametric test } \\
\text { to background } \\
\text { concentration. }\end{array}$ & NUREG- $1575^{\dagger}$ \\
\hline Pesticides/PCBs & $\begin{array}{l}\text { Not expected based } \\
\text { on process } \\
\text { knowledge }\end{array}$ & N/A & $\mathrm{N} / \mathrm{A}$ & N/A & N/A & N/A \\
\hline
\end{tabular}

${ }^{a}$ EPA Test Methods for Evaluating Solid Waste, 3rd Edition, SW-846 (EPA, 1996)

bEPA Region IX Preliminary Remediation Goals (PRGs) (EPA, 1998); will be used as risk-based PALs for this CAU

'NDEP Corrective Action Regulations (NAC, 1996a)

${ }^{d}$ FIDLER, Field Instrument for Detecting Low Energy Radiation

${ }^{e}$ National Academy of Science, Nuclear Science Series, September 1963

fNUREG Nuclear Regulatory Commission Multiagency Radiation Survey and Site Investigation Manual (MARSSIM), NRC, 1997

PAL - Preliminary action level Am - americium Pu - plutonium 
Table A.3-2

Conceptual Model

(Page 1 of 2)

\begin{tabular}{|c|c|c|}
\hline $\begin{array}{l}\text { Conceptual Model } \\
\text { Element }\end{array}$ & Assumptions & Source \\
\hline \multirow{8}{*}{ System dynamics } & $\begin{array}{l}\text { COPCs primarily in liquid form were released into the } \\
\text { soil at the decon facility trench. }\end{array}$ & \multirow{8}{*}{$\begin{array}{l}\text { 1995/96 Interviews with former } \\
\text { site personnel; similar site } \\
\text { knowledge; AEC, 1963; } \\
\text { Wilson and Terry, 1965; } \\
\text { REECo, 1964; field visits }\end{array}$} \\
\hline & $\begin{array}{l}\text { COPCs primarily in solid form were released into the soil } \\
\text { at the animal burial pit. It is unknown if the decon sump } \\
\text { trench was used as a disposal pit for solid waste other } \\
\text { than pea-gravel used in the decon pad. }\end{array}$ & \\
\hline & $\begin{array}{l}\text { Plutonium and uranium concentrations measured on the } \\
\text { animal wagons are low. These would be considered } \\
\text { worst case for radiological contamination for the vehicle } \\
\text { decon area. }\end{array}$ & \\
\hline & $\begin{array}{l}\text { Plutonium and uranium migration is known to be limited } \\
\text { in soils (Adams, 1998a). }\end{array}$ & \\
\hline & $\begin{array}{l}\text { Environmental conditions such as low annual } \\
\text { precipitation rates and high evaporation rates restrict } \\
\text { both the vertical and lateral migration potential of } \\
\text { contaminants, therefore, making groundwater } \\
\text { contamination unlikely at this site. }\end{array}$ & \\
\hline & $\begin{array}{l}\text { There is a potential for the waste trenches to be exposed } \\
\text { by erosional forces due to water runoff along the alluvial } \\
\text { fan surface. Current drainage patterns dissect parts of } \\
\text { the disturbed area in which the waste trenches are } \\
\text { believed to exist. This drainage pattern trends in a } \\
\text { general southwest to west direction. }\end{array}$ & \\
\hline & $\begin{array}{l}\text { Similar sites such as the Cactus Springs Waste } \\
\text { Trenches show that contaminants have not traveled } \\
\text { beyond extent of trenches and that action levels were } \\
\text { not exceeded for known hazardous waste. }\end{array}$ & \\
\hline & $\begin{array}{l}\text { Investigation activities at the Roller Coaster RADSAFE } \\
\text { Area may present a worst case scenario concerning } \\
\text { migration and concentration of COPCs introduced by } \\
\text { decon activities. }\end{array}$ & \\
\hline
\end{tabular}


Table A.3-2

Conceptual Model

(Page 2 of 2)

\begin{tabular}{|c|c|c|}
\hline $\begin{array}{l}\text { Conceptual Model } \\
\text { Element }\end{array}$ & Assumptions & Source \\
\hline \multirow{5}{*}{ Source location } & $\begin{array}{l}\text { Assumed that two trenches or pits exist at the DTRSA; } \\
\text { one for vehicle and personnel decon and a second for } \\
\text { animal decon and shroud/hide burial. Attempts to verify } \\
\text { the exact locations of either trench in the field have been } \\
\text { unsuccessful due to a lack of physical evidence. }\end{array}$ & \multirow{5}{*}{$\begin{array}{l}\text { Geophysical survey; } \\
\text { (SAIC, 1998) 1993-1998 } \\
\text { interviews; photo interpretation } \\
\text { (photos located in IT Public } \\
\text { Affairs office) }\end{array}$} \\
\hline & $\begin{array}{l}\text { Only two potential areas have been identified through } \\
\text { geophysical surveys and some physical evidence (see } \\
\text { Attachment 1). One of the two areas is suspected to be } \\
\text { the animal burial pit because of its location on the north } \\
\text { side of Cactus Springs Road. }\end{array}$ & \\
\hline & $\begin{array}{l}\text { Interviews suggest that dimensions of both trenches are } \\
\text { approximately } 3 \mathrm{~m} \text { deep; } 9 \text { to } 12 \mathrm{~m} \text { long; } 2 \text { to } 3 \mathrm{~m} \text { wide } \\
\text { and were excavated by a bulldozer. }\end{array}$ & \\
\hline & $\begin{array}{l}\text { Photo interpretation suggests the vehicle decon area } \\
\text { was located on the south side of the Cactus Spring Road } \\
\text { with length of trench running E-W and parallel to the } \\
\text { road. }\end{array}$ & \\
\hline & $\begin{array}{l}\text { Personnel decon area appears to be north of vehicle } \\
\text { decon but south of Cactus Springs Road. }\end{array}$ & \\
\hline $\begin{array}{l}\text { Lateral extent of potential } \\
\text { contaminants }\end{array}$ & $\begin{array}{l}\text { The lateral migration of potential contaminants are } \\
\text { assumed to be confined within the trench dimensions. }\end{array}$ & $\begin{array}{l}\text { Wilson, } 1995 \text { a and } 1995 b ; \\
\text { geophysical surveys, } \\
\text { (SAIC, 1998) }\end{array}$ \\
\hline $\begin{array}{l}\text { Vertical extent of potential } \\
\text { contaminants }\end{array}$ & $\begin{array}{l}\text { Vertical extent is not known beyond the trench/native } \\
\text { soil boundary. The waste is covered by soil, therefore, } \\
\text { reducing exposure to contaminated dust. }\end{array}$ & Similar site knowledge \\
\hline Practical constraints & $\begin{array}{l}\text { Restricted access to bombing range; meteorological; } \\
\text { heavy equipment and resource availability; health and } \\
\text { safety concerns; approval of the CAIP. }\end{array}$ & Site knowledge \\
\hline Future land use & Same as current use. & $\begin{array}{l}\text { Assumptions for the Nellis Air } \\
\text { Force Range }\end{array}$ \\
\hline Potential exposures & $\begin{array}{l}\text { Intrusion by site personnel working on range may be a } \\
\text { hazard because the site is not posted with signs or } \\
\text { restricted by fences; therefore, creating the potential for } \\
\text { exposure to contaminated soil or waste. Intrusive } \\
\text { behavior by wildlife may create exposure hazards. }\end{array}$ & Site knowledge \\
\hline
\end{tabular}




\section{A.4.0 Decisions, Input, and Strategy}

\section{A.4.1 Decisions to be Resolved by the Investigation}

Decisions to be resolved:

- Determine the locations and boundaries of the animal burial pit and the vehicle/personnel decon area.

- Determine if COPCs are present at the site.

- Determine if COPC concentrations exceed regulatory levels and/or standards for the protection of human health and the environment.

- Determine the extent of contamination with enough certainty to develop and evaluate a range of potential corrective actions, including closure in place and clean closure.

- Determine if the potential exists for future ordnance activity to expose the site.

\section{A.4.2 Inputs and Strategy}

Inputs to the decision include those elements of information used to support the decisions in addressing the identified problem. A list of information inputs, existing data, identified data gaps, and brief strategies are discussed in Table A.4-1. A more detailed discussion of investigation strategies is found in Section A.7.0 and Section 4.0 of the CAIP. 
Table A.4-1

Decision/Input Table for CAU 486

\begin{tabular}{|c|c|c|c|c|}
\hline Decision & Input & Existing Data & Data Gap & Strategy \\
\hline $\begin{array}{l}\text { Determine the location } \\
\text { of the burial pit and the } \\
\text { decon area }\end{array}$ & $\begin{array}{l}\text { Identification of site } \\
\text { boundaries }\end{array}$ & $\begin{array}{l}\text {--Interviews with site workers indicate that gravel } \\
\text { associated with the decon area was bulldozed into the } \\
\text { sump trench and covered with dirt at the conclusion of } \\
\text { activities. } \\
\text {--Geophysical evidence indicates two potential areas on } \\
\text { the north side of the Cactus Spring Road. } \\
\text {--Ground level photos taken in May } 1963 \text { show the decon } \\
\text { facility on the south side of Cactus Spring Road. } \\
\text { Skinning racks are shown on north side of Cactus Spring } \\
\text { Road. For additional details see Table A.3-2 and } \\
\text { Section } 2.2 \text { of CAIP. }\end{array}$ & $\begin{array}{l}\text { Exact location and size of the site } \\
\text { boundaries (i.e., trench/pit } \\
\text { boundaries) are unknown. Depth } \\
\text { to native soil beneath the trenches } \\
\text { is unknown. }\end{array}$ & $\begin{array}{l}\text { Trench in the locations believed to } \\
\text { be the decon area and the burial } \\
\text { pit. } \\
\text { Near-surface and subsurface field } \\
\text { screening for elevated radiological } \\
\text { levels. } \\
\text { Visual observation for subsurface } \\
\text { soil changes and miscellaneous } \\
\text { trash/debris. }\end{array}$ \\
\hline $\begin{array}{l}\text { Determine if COPCs } \\
\text { are present }\end{array}$ & COPC Identification & \multirow{2}{*}{$\begin{array}{l}\text { Animal shrouds are known to be contaminated with } \\
\text { plutonium and uranium. The levels of contamination are } \\
\text { unknown but thought to be low (less than } 100 \\
\text { micrograms of plutonium for all shrouds combined) } \\
\text { (Wilson, 1995a and 1995b; Wilson and Terry, 1965). }\end{array}$} & \multirow{2}{*}{$\begin{array}{l}\text { The presence of plutonium, } \\
\text { uranium, VOCs, SVOCs, TPH and } \\
\text { RCRA metals are unknown but } \\
\text { suspected from decon activities } \\
\text { that include waste water, doffed } \\
\text { animal shrouds, french drain } \\
\text { gravel, MEK, alcohol swabs; and } \\
\text { misc trash such as used air } \\
\text { balloons. }\end{array}$} & $\begin{array}{l}\text { Analyze soils by field screening } \\
\text { and laboratory methods for } \\
\text { COPCs as listed in Table A.3.1. }\end{array}$ \\
\hline $\begin{array}{l}\text { Determine if COPC } \\
\text { concentrations exceed } \\
\text { regulatory levels }\end{array}$ & $\begin{array}{l}\text { Action Level } \\
\text { Exceedance }\end{array}$ & & & $\begin{array}{l}\text { Compare detectable analytes to } \\
\text { established regulatory limits as } \\
\text { prescribed in Section } 3.3 \text { of the } \\
\text { CAIP. }\end{array}$ \\
\hline \multirow{4}{*}{$\begin{array}{l}\text { Determine the extent of } \\
\text { contamination with } \\
\text { enough certainty to } \\
\text { develop and evaluate a } \\
\text { range of potential } \\
\text { corrective actions for } \\
\text { the site }\end{array}$} & COPC Distribution & \multirow{2}{*}{$\begin{array}{l}\text { No data exists for distribution and migration of COPCs. } \\
\text { Assumptions are that migration of plutonium and uranium } \\
\text { is minimal due to the insoluble nature of both isotopes. } \\
\text { Original test device contained plutonium in the form of } \\
\text { metal and depleted uranium reportedly in the form of } \\
\text { oxides (Adams, 1998a). }\end{array}$} & \multirow[b]{2}{*}{$\begin{array}{l}\text { Distribution and migration, } \\
\text { including depth and lateral extent } \\
\text { of COPCs, is unknown. }\end{array}$} & \multirow{2}{*}{$\begin{array}{l}\text { Collect data of sufficient quantity } \\
\text { and quality to support the input } \\
\text { needed to resolve the decision. } \\
\text { Soil borings will be drilled to a } \\
\text { minimum depth of } 20 \mathrm{ft} \text {. }\end{array}$} \\
\hline & $\begin{array}{l}\text { Potential Corrective } \\
\text { Actions }\end{array}$ & & & \\
\hline & Meteorologic data & Available in the CAU Work Plan for TTR. & None & None \\
\hline & $\begin{array}{l}\text { Geologic/hydrologic } \\
\text { data }\end{array}$ & $\begin{array}{l}\text { Geologic summary in CAU Work Plan for TTR Depth to } \\
\text { groundwater in CAU Work Plan for TTR. }\end{array}$ & $\begin{array}{l}\text { Conductivities of soil } \\
\text { Existing cover data }\end{array}$ & $\begin{array}{l}\text { Collect geotechnical samples and } \\
\text { analyze for soil characteristics. }\end{array}$ \\
\hline $\begin{array}{l}\text { Determine if potential } \\
\text { exists for future } \\
\text { ordnance activity to } \\
\text { expose the site }\end{array}$ & $\begin{array}{l}\text { Present and future use } \\
\text { of ordnance near site }\end{array}$ & $\begin{array}{l}\text { None observed in suspected decon areas today; } \\
\text { historically, ordnance has been found within the } \\
\text { disturbed area. }\end{array}$ & $\begin{array}{l}\text { Unknown if wayward ordnance } \\
\text { would impact the site in the future. }\end{array}$ & $\begin{array}{l}\text { Evaluate site for clean closure if } \\
\text { COPC exceed regulatory levels. }\end{array}$ \\
\hline Health and Safety & $\begin{array}{l}\text { Radiological concerns } \\
\text { in subsurface, } \\
\text { predominantly } \\
\text { plutonium and uranium }\end{array}$ & $\begin{array}{l}\text { Radiological surveys for surface contamination show no } \\
\text { elevated readings; Anti-Cs only needed for intrusive work } \\
\text { where screening levels are above established screening } \\
\text { action levels. }\end{array}$ & $\begin{array}{l}\text { Subsurface radiological } \\
\text { concentrations are unknown. }\end{array}$ & $\begin{array}{l}\text { Conduct field screening of } \\
\text { excavated soil, samples and soil } \\
\text { borings. }\end{array}$ \\
\hline
\end{tabular}




\section{A.5.0 Decision Rules}

The decision rules are summary statements that specify the way data will be used to make the decisions. Data collected from the DTRSA field investigation will be evaluated and compared to both field screening and laboratory preliminary action levels, as identified in Section 3.3 of the CAIP and Table A.3-1 of the DQO worksheets, to make the following decisions:

- Presence of COPCs

- Concentrations of COPCs

- $\quad$ COPC concentrations above preliminary action levels

The following decision rules will be used to guide the investigation and subsequent data evaluation:

- If either of the following occur in the course of the investigation, then the investigation will be halted and rescoped as necessary:

- The conceptual model fails to such a degree that rescoping is required.

- Sufficient data are collected to support evaluation of closure options.

- For the subsurface investigation, if field screening indicates no COPCs above field-screening levels, then a sample at the next prescribed subsurface location will be field-screened. If no COPCs are indicated, a confirmatory laboratory sample will be collected, and the subsurface investigation will be halted for that boring.

- For the subsurface investigation, if field screening indicates the presence of COPCs above field screening levels, then the investigation will continue to determine extent of COPCs until two, consecutive samples indicate field screening results below field screening levels. Samples will be collected for laboratory analysis at those subsurface intervals that exceed field-screening levels and as stated in the previous bulleted item.

- For surface and near-surface locations, where field screening indicates the presence of COPCs above field screening levels, a sample will be collected for laboratory analysis.

- If laboratory results indicate the presence of COPCs above preliminary action levels, a CADD will be prepared.

- If no COPCs are identified above preliminary action levels, a CADD for CAUs with Contamination below Regulatory Limits will be prepared according to the outline agreed upon by NDEP and DOE/NV. This type of CADD incorporates the elements of the regular CADD and the corrective action plan and serves as the closure report for the site. 


\section{A.6.0 Decision Error}

Biased sampling will be conducted on subsurface samples at the DTRSA within identified trench boundaries and/or metallic anomalies. Because biased sampling is to be performed, assigning confidence levels is not appropriate. Biased sampling will be conducted with sampling as close to selected locations (i.e., near anomalies, within trench/pit boundary) as possible, yielding the highest confidence that the problem has been found. To ensure confidence in determining the vertical extent of contamination, two consecutive clean samples, with field screening results below field screening levels, will be obtained from soil borings drilled to collect environmental samples. These samples will be confirmed clean through off-site laboratory analysis, and will define the lower limit of the affected soils.

If, during excavation activities, the decon area cannot be identified then systematic random sampling will be conducted to collect subsurface confirmatory samples for offsite laboratory analyses. The results from the confirmatory samples will be used in evaluating and supporting future corrective action strategies. Random samples will be collected from grid cells imposed on the assumed surface area of the decontamination activities. The grid method would allow sampling that could statistically demonstrate that the contamination does not exist or is below preliminary action levels.

Statistical methods will be employed in order to form a basis for determining the appropriate number of samples to verify that constituents of concern are present below preliminary action levels. Equation 8 of Chapter 9 of SW-846 (EPA, 1996) gives the calculation of the number of samples required to measure the sample mean of $X$ of the sampled area, associated with a sample standard deviation of $\mathrm{s}$, with an acceptably small probability of error, $\alpha$, as:

$$
n=\left(t_{1-\alpha / 2, n-1} \frac{s}{[R T-X]}\right)^{2}
$$


where

$\mathrm{t}_{1-\mathrm{\alpha} / 2, \mathrm{n}-1}=$ the corresponding Student $\mathrm{t}$ value for the appropriate probability and number of degrees of freedom (=n-1)

$\mathrm{S} \quad=$ the sample standard deviation

$\mathrm{RT} \quad=$ the regulatory threshold for the constituent of concern

$\mathrm{X}=$ the mean concentration of the constituent of concern

For the Double Tracks RADSAFE Area, there is no preliminary information regarding the mean or standard deviation of the constituents of concern. In the absence of this information, each area of concern will be divided into equal grid spaces, and a systematic, random sampling pattern will be followed. The required number of samples will then be calculated from the analytical results using the above equation. If additional samples are required to demonstrate that the site is below preliminary action levels, they will be collected at a later time. If the initial sampling effort shows that there are areas which are above preliminary action levels, the contaminated areas will be investigated further. The data showing the presence of constituents of concern above preliminary action levels will be discarded for purposes of calculation, and Equation 8 will be applied again, using the new data. This will confirm that an adequate number of samples were collected and analyzed to demonstrate that the site is below preliminary action levels. 


\section{A.7.0 Sampling Design}

The field investigation at CAU 486 will consist of two phases. The first phase will involve trenching activities to locate the exact position of the decon sump/trench and the animal burial pit. The second phase will involve the drilling of boreholes and the collection of soil samples at the site. Additional details will be provided in Section 4.0 of the CAIP.

The first phase of investigation will involve the following activities:

- Conduct test pit excavations every 1.5 to $3 \mathrm{~m}$ (5 to $10 \mathrm{ft}$ ) along the excavation lines shown in Figure A.7-2 during the field investigation to determine the exact locations of decon sump/trench and animal burial pit. A decision diagram has been created for excavation activities in Figure A.7-1 along with a location map for the proposed trenches in Figure A.7-2.

- Conduct field screening on excavated soils for VOCs and radiological constituents.

- Conduct visual observation of excavated material for changes in soil characteristics that indicate the site boundary has been identified; this would include any trash/debris encountered.

- Determine borehole locations based on evidence from excavation activities.

- Place excavated soil back into the trench as close to the original spot as possible.

The second phase of investigation will involve the following activities:

- Collect bias surface and subsurface samples from borehole locations within trench/pit boundaries identified through excavation activities or at locations of geophysical anomalies.

- Collect random surface and subsurface samples if the trench/pit boundaries cannot be identified through excavation activities in the area south of the road.

- Conduct field screening for VOCs and radiological constituents at all sample locations.

- Conduct laboratory analysis on select samples based on field-screening results and other field data.

- Conduct adequate QC sampling to validate all data.

- After evaluation of acquired sampling data, advance step-out borings as needed to bound the lateral and/or vertical extent of contamination. 


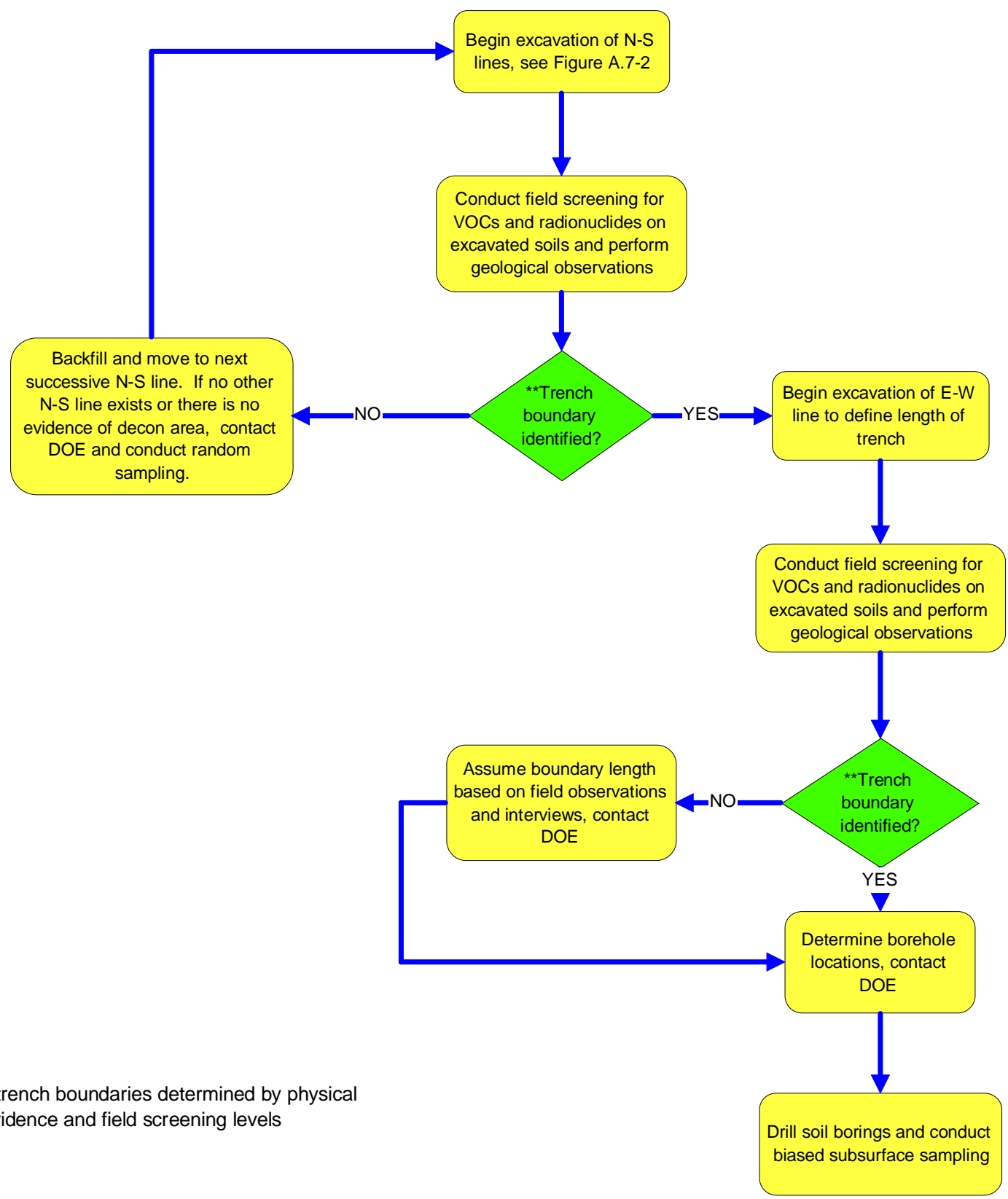

Figure A.7-1

Decision Diagram 


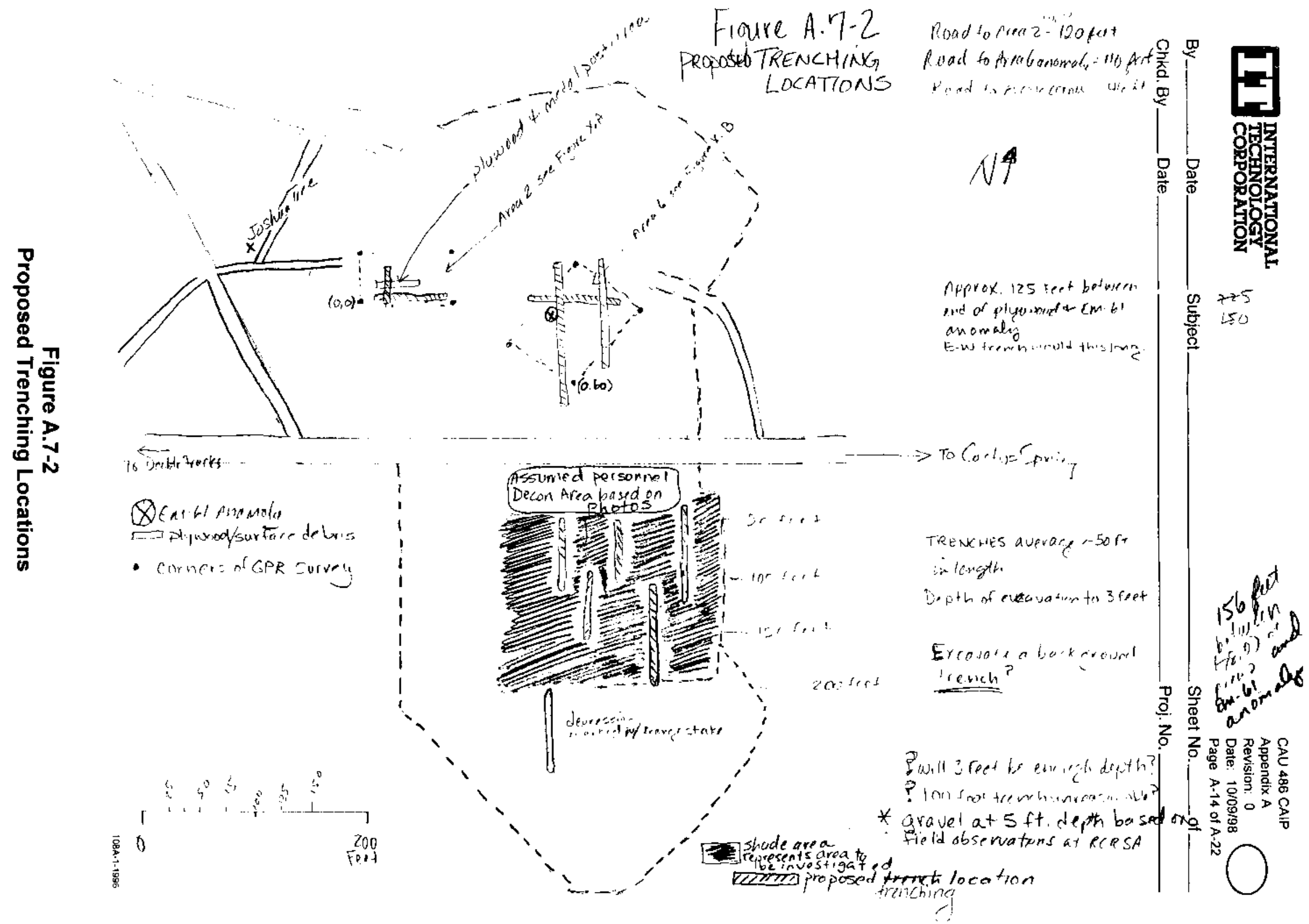


Determining the final placement of boreholes will be conducted in the field by the Site Supervisor after excavation activities have been completed.

- If the decon area and animal burial pit boundaries are identified, then boreholes will be placed in biased locations within the trench such as along the linear axis, in the area of metallic anomalies and near physical evidence seen at the surface (i.e., plywood, depressions, mounds).

- In the event trench boundaries cannot be identified on the south side of the road through excavation, then confirmatory sample locations will be based on a grid method imposed over a defined area for the collection of random samples.

Figure A.7-3 depicts possible borehole locations for the animal burial pit based on historical research and recent geophysical surveys.

Excavation techniques are outlined in more detail in the CAIP (Section 4.0 and the field instructions. Essentially, excavation lines will not be continuous but rather a 0.6- to 1-m (2- to 3-ft) line (or test pit) will be excavated (north-south). If no evidence of the feature is found, another 0.6- to 1-m (2- to 3-ft) line (or test pit) will be excavated approximately $1.5 \mathrm{~m}(5 \mathrm{ft})$ from the previous line until the boundaries are identified. The length (east-west) will mostly likely be defined by excavating step-out lines (or test pits) orientated north-south. 


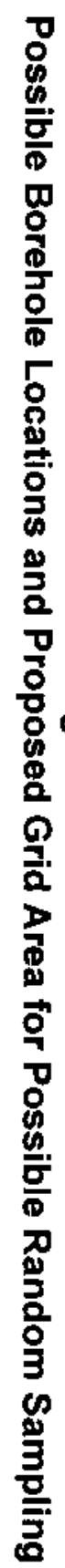

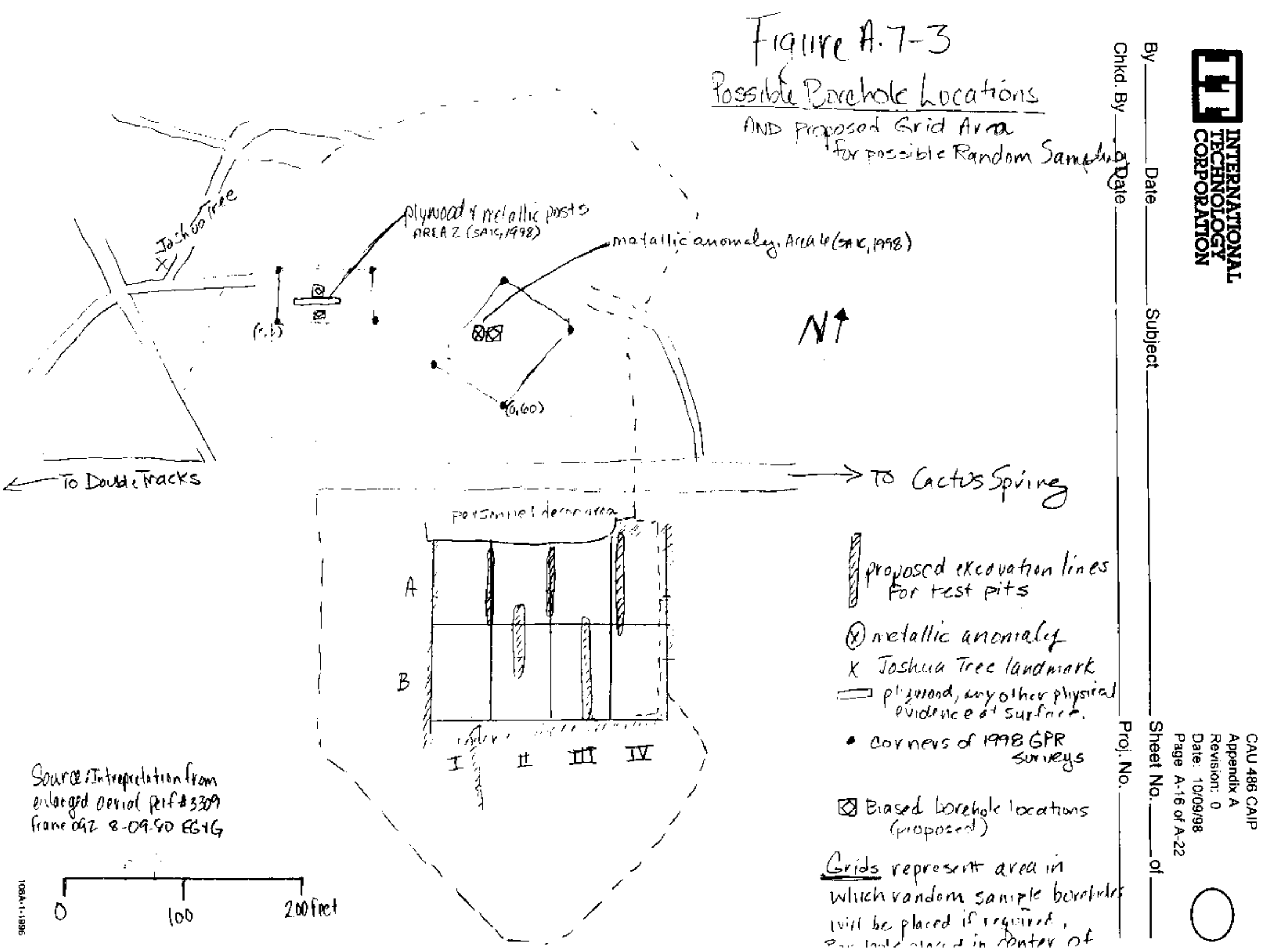




\section{Attachment 1}

Figures from Hoover, Richard (SAIC). 1998. Memo to M. Foley (SAIC) regarding "Preliminary Geophysical Results, Double Tracks RADSAFE Area Corrective Action Unit 486; Corrective Action Site 71-23-001-71DT," 22 March. Las Vegas, NV. 


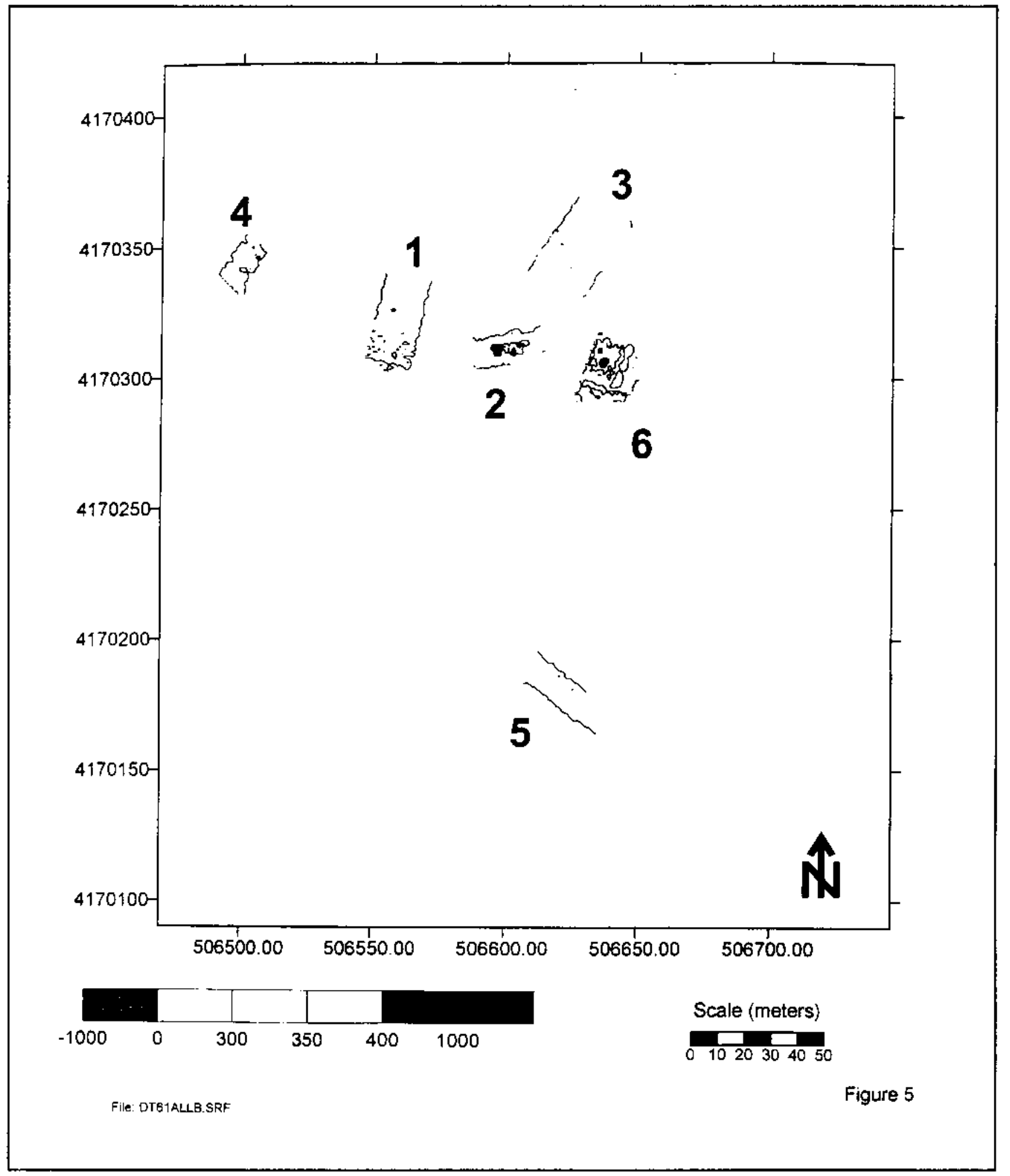

Figure A.7-4

Double Tracks RADSAFE Area CAS 71-23-001-71DT

EM61 Top Coil 


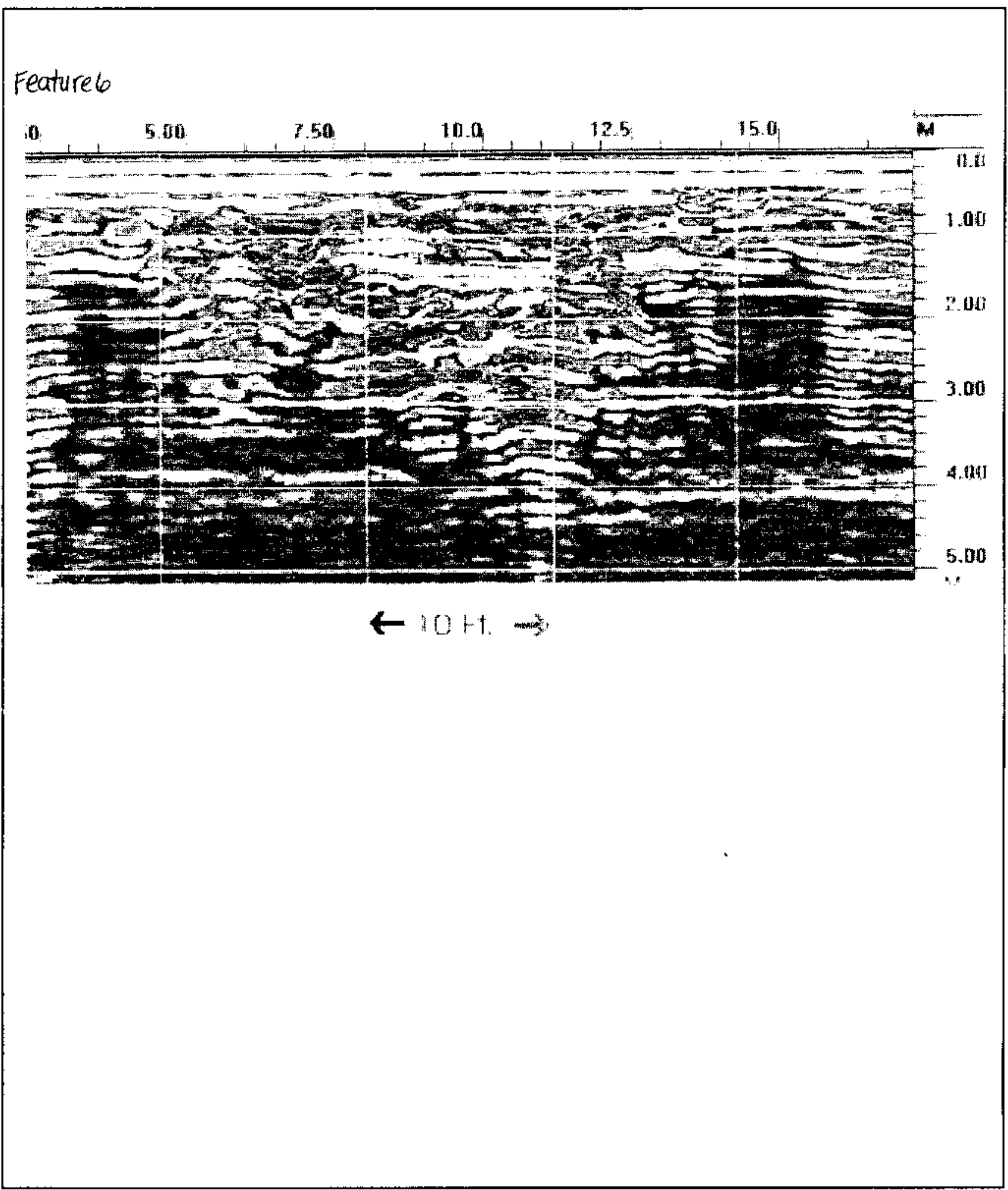

Figure A.7-5

Double Tracks RADSAFE Area GPR Excavation Examples 


\section{Attachment 2}

"Methodology for Determining Preliminary Action Levels for CAU 407, Roller Coaster RADSAFE Area" (Adams, 1998C) 


\section{Memorandum}

To:

Robert L. McCall

Dorte:

June 16, 1998

From:

Steven R. Adams SDO

Project No. 772847.010201

Subject:

\section{METHODOLOGY FOR DETERMINING PRELIMINARY ACTION LEVELS FOR CAU 407, THE ROLLER COASTER RADSAFE AREA}

\section{Introduction}

The Nevada Division of Environmental Protection (NDEP) has requested that a preliminary action level (PAL) be established for on-site field screening of soil samples. In addition, NDEP requests that the method used for determining the PAL and the results of this method be sent to them prior to drilling activities. This memorandum presents a methodology for determining an on-site field screening PAL for gross alpha activity, gross beta activity, and gamma activity at the Roller Coaster Radsafe Area (RCRSA). The PAL determination will be performed one time and will be done prior to starting field work. The PAL determination is a separate task from the daily field instrument background checks that are performed to check consistency in instrument response.

A PAL is defined such that the probability of a false positive or false negative decision on whether a soil sample is contaminated above background will not exceed 5 percent. A soil sample with activity exceeding any PAL requires that the information be documented and the investigation to be continued to delineate the extent of the contamination. Additionally, the information may also be used to select discretionary samples to be submitted to an analytical laboratory.

\section{Methodology}

Twenty surface soil samples will be taken from an area (approximately 75 feet by 75 feet) that is south of Browne's Lake Road and west of Main Road (Attachment 1). The sampling location is in the vicinity of the RCRSA. However, the sampling location is up gradient and away from the traffic routes used during the RCRSA operational period. The sampling location should ensure that the radionuclide concentration in the soil is not significantly different from soil samples taken at other background locations in Nevada.

Each of the twenty soil samples will be surveyed for gross alpha activity, gross beta activity, and gamma activity. The gross alpha and the gross beta activity measurements will be taken with the NE Technology "Electra" alpha/beta survey instrument calibrated to plutonium$239 / 240$ and strontium/yttrium-90 in units of disintegrations per minute per 100 square 
centimeters $\left(\mathrm{dpm} / 100 \mathrm{~cm}^{2}\right)$. The gross alpha and gross beta activity measurements will be recorded by placing the detector at the soil surface for a one minute integrated count. The gamma measurements will be taken with a Field Instrument for Detecting Low Energy Radiation (FIDLER) calibrated to americium-241 in units of counts minute (cpm). The measurements will be recorded at the soil surface by placing the FIDLER detector at the soil surface for a one minute count or until the count rate stabilizes. The results of all alpha, beta, and garnma measurements will be recorded.

The average activity for the twenty gross alpha, gross beta, and gamma measurements will be calculated and recorded. The standard deviation for each set of twenty measurements will be defined as equal to the square root of the average activity. The PAL for each type of activity will be equal to the average activity plus two times the standard deviation of the average activity.

\section{Conclusion}

A method has been presented for determining the PALs at the RCRSA. The results of this method will be sent to NDEP prior to drilling activities being conducted. The PALs will ensure that there is only a 5 percent probability that a soil sample with a background concentration of radionuclides will be discerned as having contamination. In addition, the PAL will ensure that there is only a 5 percent probability that a soil sample with contamination will be discerned as having a background concentration of radionuclides.
cc: Mike O'Hagan
Mike Foley
Laura Tryboski
Jared Dominick
Chrono Files 


\section{Appendix B}

\section{Project Organization}




\section{B.1.0 Project Organization}

The DOE/NV Project Manager is Janet Appenzeller-Wing, telephone (702) 295-0461.

The names of the project Health and Safety Officer and the Quality Assurance Officer can be found in the appropriate DOE/NV plan. However, personnel are subject to change, and it is suggested that the Project Manager be contacted for further information. The Task Manager will be identified in the FFACO Biweekly Activity Report prior to the start of field activities. 


\section{Appendix C}

\section{NDEP Document Review Sheet}


NEVADA ENVIRONMENTAL RESTORATION PROJECT

\section{DOCUMENT REVIEW SHEET}

(Page 1 of 1$)$

\begin{tabular}{|c|c|c|c|c|c|}
\hline \multicolumn{4}{|c|}{$\begin{array}{l}\text { 1. Document Title/Number: Draft Corrective Action Investigation Plan for CAU } 486 \text { Double Tracks } \\
\text { RADSAFE Area, Nellis Air Force Range, Nevada }\end{array}$} & \multicolumn{2}{|l|}{ 2. Document Date: _ August 1998} \\
\hline \multicolumn{4}{|c|}{ 3. Revision Number: $\quad 0$} & \multicolumn{2}{|l|}{ 4. Originator/Organization: IT Corporation } \\
\hline \multicolumn{4}{|c|}{ 5. Responsible DOE/NV ERP Subproject Mgr.: Kevin Cabble } & \multicolumn{2}{|c|}{ 6. Date Comments Due: September 25, 1998} \\
\hline \multicolumn{6}{|c|}{ 7. Review Criteria: Full } \\
\hline \multicolumn{4}{|c|}{ 8. Reviewer/Organization/Phone No.: NDEP } & \multicolumn{2}{|l|}{ 9. Reviewer's Signature: } \\
\hline $\begin{array}{l}\text { 10. Comment } \\
\text { Number/ } \\
\text { Location }\end{array}$ & 11. Type* & 12. Comment & 13. Comment Response & & 14. Accept \\
\hline \begin{tabular}{|} 
1) Page 19, \\
Section 3.3 \\
Preliminary \\
Action Levels, \\
$3^{\text {rd }}$ Bulleted \\
Item
\end{tabular} & & $\begin{array}{l}\text { The Nuclear Regulatory Commission (NRC), } \\
\text { Multi-Agency Radiation Survey and Site Investigation } \\
\text { Manual (MARSSIM) should not be listed as a source } \\
\text { of preliminary action levels unless the MARSSIM } \\
\text { method is to be used for determining appropriate } \\
\text { clean-up levels. If MARSSIM is to be used, this should } \\
\text { also be indicated elsewhere in this plan. }\end{array}$ & $\begin{array}{l}\text { The MARSSIM was incorrectly } \\
\text { To more adequately describe th } \\
\text { nary action levels for radioactiv } \\
\text { CAIP with the following text: } \\
\text { "The preliminary action levels fo } \\
\text { concern will be defined in accor } \\
\text { Multi-Agency Radiation Survey } \\
\text { (NRC, 1997). The MARSSIM p } \\
\text { conducting, and documenting re } \\
\text { guidance on how to evaluate sL } \\
\text { regarding whether or not the rac } \\
\text { concentration in a background } \\
\text { difference in the distribution of t } \\
\text { background area and the areas } \\
\text { presence of residual radioactivi } \\
\text { Section } 8.4 .1 \text { of MARSSIM, son } \\
\text { than some background area res } \\
\text { concentrations. The result of th } \\
\text { not the areas of concern within } \\
\text { background area." }\end{array}$ & $\begin{array}{l}\text { eferenced as a source for supplying PALs. } \\
\text { use of the MARSSIM in regards to prelimi- } \\
\text { COPCs, Section 3.3.3 was added to the } \\
\text { radioactive contaminants of potential } \\
\text { lance with the guidance described in the } \\
\text { and Site Investigation Manual (MARSSIM) } \\
\text { ovides detailed guidance for designing, } \\
\text { diological surveys. MARSSIM provides } \\
\text { vey results prior to making a decision } \\
\text { ionuclide concentration at a site exceeds the } \\
\text { rea. The assumption will be made that any } \\
\text { e radionuclide concentrations between the } \\
\text { of concern within the DTRSA is due to the } \\
\text { in addition to background. As stated in } \\
\text { e DTRSA analytical results may be larger } \\
\text { ults, while still not exceeding background } \\
\text { hypothesis testing determines whether or } \\
\text { he DTRSA are deemed to exceed the }\end{array}$ & Yes \\
\hline
\end{tabular}

a Comment Types: $M=$ Mandatory, $S=$ Suggested.

Return Document Review Sheets to DOE/NV Environmental Restoration Division, Attn: QAC, M/S 505. 


\section{Distribution}

*Provide copy in distribution of Rev. 0 and subsequent revisions if applicable. Copies of the approved revision only should be distributed to the others.

Paul J. Liebendorfer

State of Nevada

Bureau of Federal Facilities

Division of Environmental Protection

333 W. Nye Lane, Room 138

Carson City, NV 89706-0851

Supervisor

State of Nevada

Bureau of Federal Facilities

Division of Environmental Protection

555 E. Washington, Suite 4300

Las Vegas, NV 89101

Sabrina Lawrence

Environmental Restoration Division

DOE/Nevada Operations Office

P.O. Box 98518, M/S 505

Las Vegas, NV 89193-8518

Janet Appenzeller-Wing

Environmental Restoration Division

DOE/Nevada Operations Office

P.O. Box 98518, M/S 505

Las Vegas, NV 89193-8518

Kevin Cabble

Environmental Restoration Division

DOE/Nevada Operations Office

P.O. Box 98518, M/S 505

Las Vegas, NV 89193-8518

Technical Information Resource Center

DOE/Nevada Operations Office

P.O. Box 98518, M/S 505

Las Vegas, NV 89193-8518
2 (Controlled)* $^{*}$

1 (Controlled)*

1 (Controlled)*

1 (Uncontrolled)*

1 (Uncontrolled)*

1 (Uncontrolled) 
U.S. Department of Energy

1 (Uncontrolled, electronic)

Office of Scientific and Technical Information

175 Oak Ridge Turnpike

P.O. Box 62

Oak Ridge, TN 37831

Manager Southern Nevada FFACO Public Reading Room

P.O. Box 98521, M/S NLV040

1 (Controlled)

Las Vegas, NV 89193-8521

1 (Uncontrolled)

Manager Northern Nevada FFACO

1 (Uncontrolled)

Public Reading Room

c/o Rosa Silver

IT Corporation

P.O. Box 93838

Las Vegas, NV 89193

Rosa Silver

1 (Controlled)

IT Corporation

P.O. Box 93838

Las Vegas, NV 89193

Steve Nacht

1 (Uncontrolled)*

Bechtel Nevada

P.O. Box 98521, M/S NTS306

Las Vegas, NV 89193-8521

Jerry Bonn

1 (Uncontrolled)*

Bechtel Nevada

P.O. Box 98521, M/S NTS306

Las Vegas, NV 89193-8521

U.S. Air Force Liaison Office

2 (Uncontrolled)*

DOE/Nevada Operations Office

P.O. Box 98518, M/S 505

Las Vegas, NV 89193-8518

Cheryl Rodriguez

1 (Uncontrolled)*

HSI GeoTrans

P.O. Box 93838

Las Vegas, NV 89193 
Mark DiStefano

IT Corporation

P.O. Box 93838

Las Vegas, NV 89193

Mary Todd

SAIC

P.O. Box 93838

Las Vegas, NV 89193

Dawn Arnold

SAIC

P.O. Box 93838

Las Vegas, NV 89193

IT Corporation Central Files

IT Corporation

P.O. Box 93838

Las Vegas, NV 89193

Dustin Wilson

SAIC

P.O. Box 93838

Las Vegas, NV 89193
1 (Uncontrolled)*

1 (Uncontrolled)*

1 (Uncontrolled)*

1 (Uncontrolled)*

1 (Uncontrolled) 